\title{
AUTHORIZING WIRETAP APPLICATIONS UNDER TITLE III: ANOTHER DISSENT TO GIORDANO AND CHAVEZ
}

\author{
Charles A. Pulaski, Jr. $\dagger$
}

\section{INTRODUCTION}

Title III of the Omnibus Crime Control and Safe Streets Act of 1968 prohibits the unauthorized interception of oral and wire communications except pursuant to a court order. ${ }^{1}$ This statute "represents a comprehensive attempt by Congress to promote more effective control of crime while protecting the

$\dagger$ Associate Professor of Law, University of Iowa. B.A. 1964, LL.B. 1967, Yale University. The author is indebted to the Old Gold Foundation of the University of Iowa, under the auspices of whose summer fellowship program he prepared this article. He also would like to thank the several members of the faculty at the University of Iowa. Law School who read and commented on the article in manuscript form. He is grateful as well to Attorney James Jay Hogan, who started the whole thing, see note 24 infra, and who kindly provided copies of unreported court decisions and other relevant documents.

118 U.S.C. $\$ \S 2510-20$ (1970). There are several exceptions to Title III's prohibition of unauthorized electronic interceptions. The statute does not apply, for example, if a party to the wire or oral communication consents to its interception. Id. § $2511(2)(\mathrm{c}) . C f$. United States v. White, 401 U.S. 745, 753 (1971). But of. Arnold v. County Court, 51 Wis. 2d 434, 442-43, 187 N.W.2d 354, 358-59 (1971). Nor does the statute apply to the interception of oral communications in which the participants have no reasonable expectation of privacy. See 18 U.S.C. \$ 2510(2) (1970); cf. United States v. Banks, 374 F. Supp. 321,327 (D.S.D. 1974). Compare United States v. Hall, 488 F.2d 193 (9th Cir. 1973), and United States v. Pui Kan Lam, 483 F.2d 1202 (2d Cir. 1973), cert. denied, 415 U.S. 984 (1974), with North v. Superior Court, 8 Cal. 3d 301, 502 P.2d 1305, 104 Cal. Rptr. 833 (1972). Congress also excluded from the statute's coverage whatever constitutional authority the President may possess to employ electronic interceptions to protect the nation's security against foreign or domestic threats. 18 U.S.C. \$ $2511(3)$ (1970). In United States v. United States District Court, 407 U.S. 297 (1972), the Supreme Court ruled without dissent that the President's constitutional powers did not include authority to employ electronic surveillances to protect the nation from domestic violence or subversion without prior judicial approval. Id. at 320-21. The Court carefully refrained from considering whether the same fourth amendment requirement would apply in the case of a foreign threat. Id. at 321-22. Some lower courts believe prior judicial approval would not be necessary in such cases. United States v. Brown, 484 F.2d 418 (5th Cir. 1973); Zweibon v. Mitchell, 363 F. Supp. 936 (D.D.C. 1973); $f f$. United States v. Butenko, 494 F.2d 593 (3d Cir. 1974). But cf. Russo v. Byrne, 409 U.S. 1013 (1972) (Douglas, J., dissenting from denial of certiorari); United States v. Ehrlichman, 376 F. Supp. 29 (D.D.C. 1974). Title III also permits communications common carriers to intercept and disclose wire communications in connection with the rendition of service or the protection of the carrier's rights or property. 18 U.S.C. $\$ 2511$ (2)(a) (1970). See United States v. Freeman, 373 F. Supp. 50 (S.D. Ind. 1974). 
privacy of individual thought and expression."2 It sets forth an elaborate statutory procedure-intended to satisfy the Fourth Amendment ${ }^{3}$-by which federal and state officials can obtain court orders to conduct electronic surveillances in certain relatively serious cases. ${ }^{4}$ In exercising their judicial responsibilities

${ }^{2}$ United States v. United States District Court, 407 U.S. 297, 302 (1972).

${ }^{3}$ United States v. Bobo, 477 F.2d 974, 980 (4th Cir. 1973); United States v. Cafero, 473 F.2d 489, 495 (3d Cir. 1973), cert. denied, 417 U.S. 918 (1974); United States v. Cox, 462 F.2d 1293, 1303 (8th Cir. 1972), cert. denied, 417 U.S. 918 (1974); United States v. Narducci, 341 F. Supp. 1107, $1109-10$ (E.D. Pa. 1972). See S. ReP. No. 1097, 90th Cong., 2d Sess., 1968 U.S. Code Cong. \& Ad. News 2113, 2153, 2161-63 [hereinafter cited as S. REP., with pagination cited to 1968 U.S. CODE CONG. \& AD. News].

Virtually every court which has considered the constitutionality of Title III has sustained the statute. See, e.g., United States v. Ramsey, 503 F.2d 534 (7th Cir. 1974); United States v. Tortorello, 480 F.2d 764, 773-75 (2d Cir.), cert. denied, 414 U.S. 866 (1973); United States v. Bobo, supra at 981; United States v. Cafero, supra at 501; United States v. Cox, supra at 1304. Contra, United States v. Whitaker, 343 F. Supp. 358 (E.D. Pa. 1972), rev'd, 474 F.2d 1246 (3d Cir.), cert. denied, 412 U.S. 953 (1973). For discussions of the constitutionality of Title III, see Burpo, Electronic Surveillance by Leave of the Magistrate: The Case for the Prosecution, 38 TENn. L. Rev. 14 (1970); Schwartz, The Legitimation of Electronic Eavesdropping: The Politics of "Law and Order", 67 Mrch. L. Rev. 455 (1969); Spritzer, Electronic Surveillance by Leave of the Magistrate: The Case in Opposition, 118 U. P. L. REv. 169 (1969); Note, Federal Decisions on the Constitutionality of Electronic Surveillance Legislation, 11 AM. CRIM. L.Q. 639 (1973).

+ Title III permits federal courts to authorize or approve electronic interceptions which constitute or may constitute evidence of certain specified federal crimes. 18 U.S.C. $\$ 2516(1)(1970)$. The statute contemplates that under most conditions the court will issue the interception order before the interceptions occur. In emergency situations involving national security or organized crime, law enforcement officials may conduct electronic surveillances without a prior court order provided that they obtain judicial approval within 48 hours. Id. $\S 2518(7)$. See Note, Wiretapping and Electronic Surveillance-Title III of the Crime Control Act of 1968, 23 Rutgers L. Rev. 319, 350-66 (1969). Although the statute requires interception orders to specify the type of communications to be intercepted, 18 U.S.C. $\$ \S 2518(4)(a)$, (c) (1970), it permits the interception and use of communications not described in the court order if those communications relate to criminal activity for which an interception order could issue. Id. $\$ 2517(5)$. The courts have sustained the constitutionality of this provision by analogy to the plain view doctrine, United States v. Cox, 449 F.2d 679, 686-87 (10th Cir. 1971), cert. denied, 406 U.S. 934 (1972), or by characterizing criminal conversations as the equivalent of contraband, United States v. Escandar, 319 F. Supp. 295 (S.D. Fla. 1970), rev'd on other grounds sub nom. United States v. Robinson, 468 F.2d 189 (5th Cir. 1972). See S. ReP., supra note 3, at 2189.

When the government seeks authority to intercept communications relating to a crime specified in the statute, Title III permits a federal judge to issue an order authorizing the interception only upon a detailed showing that probable cause exists to believe that the subjects of the proposed surveillance are committing or have committed that crime and that the surveillance will intercept communications relating to the offense. 18 U.S.C. $\$ \S 2518(3)(a)$, (b), (d) (1970). In addition, the issuing court must find that the use of other investigative techniques to obtain the necessary evidence is unlikely to succeed or is too dangerous. $I d$. $\$ 2518(3)(\mathrm{c})$.

Title III also requires each interception order to include various provisions intended to limit the scope and duration of the electronic surveillance to the circumstances justifying its use. S. REP., supra note 3, at 2192-93. The order must specify the 
under Title III, courts have frequently remarked on the extraordinary invasion of individual privacy made possible by electronic surveillance, and have asserted that no such invasions

maximum period during which communications may be intercepted, in no case to exceed 30 days, and must provide that the electronic surveillance must cease as soon as the government intercepts the communications specified in the statute. 18 U.S.C. $\S$ \$ $518(4)(e),(5)(1970)$. Commonly, however, such orders permit the government to continue its interceptions until it has secured sufficient evidence to identify all the participants in a criminal venture and the full scope of their operations. See, e.g., United States v. James, 494 F.2d 1007, 1019-20 (D.C. Cir. 1974); United States v. Cox, 462 F.2d 1293, 1300-01 (8th Cir. 1972), cert. denied, 417 U.S. 918 (1974); cf. United States v. Poeta, 455 F.2d 117 (2d Cir.), cert. denied, 406 U.S. 948 (1972). The government also can obtain extension orders permitting interceptions to continue after the original order lapses, although whether a further showing of probable cause is necessary is unclear. See United States v. Poeta, supra.

Each Title III court order must provide that the authorized electronic surveillance will commence as soon as practicable and will be conducted so as to minimize the interception of communications not subject to interception under the statute. 18 U.S.C. $\S 2518(5)$ (1970). The issuing judge also may require the government to make periodic reports during the duration of the surveillance in order to indicate progress made and the need for continued interception. Id. \$ 2518(6); S. REP., supra note 3, at 2192-93. See United States v. Cox, supra at 1301; United States v. Mainello, 345 F. Supp. 863, 872-73 (E.D.N.Y. 1972); United States v. Sklaroff, 323 F. Supp. 296, 306-07 (S.D. Fla. 1971). The minimization requirement of $\S 2518(5)$ serves to prevent Title III electronic interceptions from constituting a general search in violation of the fourth amendment. United States v. King, 335 F. Supp. 523, 532 (S.D. Cal. 1971), rev'd in part, 478 F.2d 494 (9th Cir.), cert. denied, 414 U.S. 846 (1973); United States v. Sklaroff, supra at 306; S. REP., supra note 3, at 2192 . However, the lower courts have interpreted those requirements in significantly different fashions. Some courts believe that the failure to minimize the interception of innocent communications requires the suppression of all intercepted communications, including those which constitute evidence of crime. United States v. George, 465 F.2d 772 (6th Cir. 1972); United States v. Scott, 331 F. Supp. 233 (D.D.C. 1971). Other courts are more tolerant of the interception of innocent communications and even in the case of unjustifiable failures to minimize interceptions will suppress only non-incriminatory communications. See, e.g., United States v. Cox, supra; United States v. Askins, 351 F. Supp. 408 (D. Md. 1972); United States v. Mainello, supra; United States v. King, supra; Spease v. State, 319 A.2d 560 (Md. Ct. Spec. App. 1974). See Note, Minimization of Wire Interception: Presearch Guidelines and Postsearch Remedies, 26 Stan. L. Rev. 1411 (1974); Note, Minimization: In Search of Standards, 8 SUFF. U.L. REv. 60 (1973).

In Berger v. New York, 388 U.S. 41, 60 (1967), the Supreme Court condemned a state wiretapping statute on multiple grounds including the absence of any requirement that applications demonstrate exigent circumstances justifying the failure to give prior notice. Title III purports to avoid this constitutional deficiency in two ways. First, it requires a showing of necessity. 18 U.S.C. $§ 2518(3)(c)$ (1970). Electronic interceptions are permissible under the statute only when they provide the sole reasonably available means to obtain the necessary evidence. United States v. Sklaroff, supra at 307-08. See S. ReP., supra note 3, at 2190; A.B.A. Project on Minimum Standards for Criminal Justice, Standards Relating to Electronic Surveillance $137-40$ (Tent. Draft, 1968) [hereinafter cited as A.B.A. Standarps Relating to Electronic SurveillancE]. Second, Title III also requires the issuing court to order post-interception notice that surveillance occurred. 18 U.S.C. $\$ 2518(8)(d)(1970)$. Only those individuals who were identified as subjects of the surveillance are entitled to such notice automatically. Others whose communications were intercepted are not entitled to notice under $\S 2518(8)$ (d) unless the issuing judge concludes in his discretion that 
are lawful unless conducted in strict compliance with the provisions of the statute. ${ }^{5}$

One of the statutory requirements for federal government attorneys who wish to seek a court order permitting electronic interceptions is first to obtain the approval of "the Attorney General, or any Assistant Attorney General specially designated by the Attorney General." 6 When applying to a federal judge for a Title III order, the government attorney also must state under oath the name of the individual who authorized the application; the federal judge must identify that official as "the authorizing officer" in the court order itself. ${ }^{7}$

notice would be appropriate. See United States v. Forlano, 358 F. Supp. 56, 58 (S.D.N.Y. 1973); United States v. Ripka, 349 F. Supp. 539, $541-42$ (E.D. Pa. 1972), aff'd, 480 F.2d 919 (3d Cir.), cert. denied, 414 U.S. 977 (1973). Although the government may not dispense altogether with the service of notice, suppression will not follow if the government fails to give notice within the 90-day period specified by the statute. Compare United States v. Eastman, 465 F.2d 1057 (3d Cir. 1972), with United States v. Wolk, 466 F.2d 1143 (8th Cir. 1972); United States v. Smith, 463 F.2d 710 (10th Cir. 1972) (alternative holding); and United States v. Forlano, supra. Furthermore, as the section permits, courts will postpone the service of notice if circumstances constituting good causes so require. United States v. Lawson, 334 F. Supp. 612 (E.D. Pa. 1971); United States v. Cantor, 328 F. Supp. 561 (E.D. Pa. 1971), aff'd, 470 F.2d 890 (3d Cir. 1972). See S. REP., supra note 3, at 2194.

${ }^{5}$ Gelbard v. United States, 408 U.S. 41, 46 (1972); United States v. King, 478 F.2d 494, 503 (9th Cir.), cert. denied, 414 U.S. 846 (1973); United States v. Cox, 449 F.2d 679, 684 (10th Cir. 1971), cert. denied, 406 U.S. 934 (1972); United States v. Mainello, 345 F. Supp. 863, 867 (E.D.N.Y. 1972); United States v. Baldassari, 338 F. Supp. 904, 905-07 (M.D. Pa. 1972).

6 The Attorney General, or any Assistant Attorney General specially designated by the Attorney General, may authorize an application to a Federal Judge of competent jurisdiction for, and such judge may grant in conformity with section 2518 of this chapter an order authorizing or approving the interception of wire or oral communications by the Federal Bureau of Investigation, or a Federal agency having responsibility for the investigation of the offense as to which the application is made.

18 U.S.C. § 2516(1) (1970). Section 2516(2) similarly restricts electronic interceptions by state officials, permitting only the chief prosecuting attorney of the state, or a political subdivision thereof, to apply to state courts for interception orders. See also S. REP., supra note 3, at 2187.

7 The relevant provisions of section 2518 are:

(1) Each application for an order authorizing or approving the interception of a wire or oral communication shall be made in writing upon oath or affirmation to a judge of competent jurisdiction and shall state the applicant's authority to make the application. Each application shall include the following information:

(a) the identity of the investigative or law enforcement officer making the application, and the officer authorizing the application.

....

(4) Each order authorizing or approving the interception of any wire or oral communication shall specify-

(d) the identity of the agency authorized to intercept the communications and of the person authorizing the application. 
The legislative history of the electronic surveillance stat$u^{8} e^{8}$ makes the purpose of these provisions reasonably apparent: Congress wanted a politically accountable official to formulate Justice Department policies for the use of electronic surveillance techniques and to decide whether those policies required electronic intrusions in each individual case. ${ }^{9}$ The Attorney General and his Assistant Attorney General are, of course, among the most senior officials of the Justice Department. They are also politically accountable in that they are appointed by the President with the consent of the Senate. ${ }^{10}$ As a Justice Department spokesman pointed out in 1961, requiring the Attorney General or an Assistant Attorney General to authorize all federal Title III applications gives "greater assur-

${ }^{8}$ The most comprehensive source of legislative history concerning Title III is Senate Report No. 1097, supra note 3, which purports to serve as "a comprehensive and in-depth analysis . . . in order to make explicit congressional intent in this area." Id. 2177. See also Hearings before the Subcomm. on Criminal Laws and Procedures of the Senate Comm. on the Judiciary, 90th Cong., 1st Sess. (1967); A.B.A. Standards Relating to Electronic Surveillance, supra note 4. However, the Senate Report deals with Title III's authorization and identification requirements in only a few sentences. S. REP., supra note 3 , at $2185,2187,2192$. For a more complete discussion of the legislative history of these provisions, see United States v. Focarile, 340 F. Supp. 1033, 1053-57 (D. Md.), aff'd sub nom. United States v. Giordano, 469 F.2d 522 (4th Cir. 1972), aff'd, 416 U.S. 505 (1974). [The district court opinion is cited hereinafter as Focarile, the court of appeals opinion as Giordano I, and the Supreme Court opinion as Giordano II.]

" [Section 2516(I)] centralizes in a publicly responsible official subject to the political process the formulation of law enforcement policy on the use of electronic surveillance techniques. Centralization will avoid the possibility that divergent practices might develop. Should abuses occur, the lines of responsibility lead to an identifrable person. This provision in itself should go a long way toward guaranteeing that no abuses will happen.

S. REP., supra note 3, at 2185 . The Report also states that fixing responsibility is the statutory purpose of the provisions requiring the Title III application and court order to state the identity of the authorizing officer. Id. 2189, 2192. See also text accompanying notes 181 \& 262-64 infra.

${ }_{10} 28$ U.S.C. $\$ \S 503,506$ (1970). Title III makes no specific reference to the Deputy Attorney General, whom the President also appoints with the consent of the Senate. Id. \$ 504. However, the courts presently agree that, as Deputy Attorney General, Acting Attorney General Richard Kleindienst could properly authorize Title III applications. United States v. Lucido, 373 F. Supp. 1142, 1145, 1147-51 (E.D. Mich. 1974); United States v. Curreri, 363 F. Supp. 430, 434 (D. Md. 1973). See United States v. Aquino, 338 F. Supp. 1080, 1084 n.3 (E.D. Mich. 1972). On the other hand, the courts presently disagree concerning the authority of a specially designated Acting Assistant Attorney General lawfully to approve a Title III application. Compare United States v. Acon, 377 F. Supp. 649 (W.D. Pa. 1974), and United States v. Boone, 348 F. Supp. 168 (E.D. Va. 1972), with United States v. Vigi, 350 F. Supp. 1008 (E.D. Mich. 1972) (alternative holding). See also United States v. Pellicci, 504 F.2d 1106 (1st Cir. 1974) (acting as Attorney General, the Solicitor General can properly specially designate an Assistant Attorney General to authorize application). 
ance of a responsible executive determination of the need and justifiability of each interception."11 The statutory requirements that each Title III application and court order identify the authorizing officer serve to assure that a particular individual makes the responsible executive determination which Congress wished to require; if abuses did occur, Congress wanted to be certain that the lines of responsibility pointed to a specific person. ${ }^{12}$

The official reports which describe the Justice Department's use of the Title III procedure indicate that the government has made large-scale use of court-ordered electronic interceptions. ${ }^{13}$ But while John Mitchell was Attorney General, the degree of high-level screening which occurred within the Justice Department was more apparent than real. Lower level officials did reject authorization requests because the documents submitted by field attorneys did not satisfy statutory requirements or were improper as to form. Few applications, however, were rejected at the very highest level. ${ }^{14}$

"Statement by Assistant Attorney General Herbert J. Miller, Jr., concerning S. 1495, 87th Cong., 1st Sess. (1961), quoted in Focarile, 340 F. Supp. at 1053. This bill originally proposed that the Attorney General could delegate the decision to authorize a wiretap application to any official of the Department of Justice or to any United States Attorney. Miller proposed that delegation be limited in such cases to the nine Assistant Attorneys General, a limitation which then appeared in every subsequent proposal examined by the Congress. Id. at 1054-55.

${ }^{12}$ S. ReP., supra note 3, at 2189,2192 . See United States v. Ceraso, 467 F.2d 647, 650-52 (3d Cir. 1972); United States v. Pisacano, 459 F.2d 259, 264 n.5 (2d Cir. 1972) (dictum), vacated (in light of Giordano), 417 U.S. 903 (1974); United States v. Narducci, 341 F. Supp. 1107, 1110 (E.D. Pa. 1972); Focarile, 340 F. Supp. at 1055-57. But see United States v. Chavez, 416 U.S. $562,575-79$ (1974).

${ }^{13}$ The following chart indicates the number of installations of Title III interception devices made by federal agents pursuant to court order.

\begin{tabular}{|c|c|c|c|}
\hline Year & Applications Submitted & Applications Granted & Installations \\
\hline 1968 & 0 & 0 & 0 \\
\hline 1969 & 34 & 33 & 30 \\
\hline 1970 & 183 & 183 & 180 \\
\hline 1971 & 285 & 285 & 281 \\
\hline 1972 & 206 & 206 & 205 \\
\hline 1973 & 130 & 130 & 130 \\
\hline
\end{tabular}

Admin. Office of the U.S. Courts, Reports on Applications for Orders AuTHORIZING OR APPROVING the INTERCEPTION OF Wire OR ORAL CoMmunications (1968-73). For a detailed analysis of electronic surveillance by the federal and state governments during the period 1968-June 1971, see H. Schwartz, A REPORT ON THE Costs and Benefits of Electronic Surveillance (1971).

${ }^{14}$ In March 1973, following remand from the United States Court of Appeals for the Fifth Circuit, United States v. Robinson, 472 F.2d 973 (5th Cir. 1973) (en banc), remanding 468 F.2d 189 (5th Cir. 1972), Judge Mehrtens of the Southern District of 
On the other hand, during the first years that the Justice Department employed Title III, all external indications suggested that government attorneys were seeking court orders only after scrupulous compliance with the authorization requirements of the statute. All the government documents involved in a Title III proceeding followed a common form. ${ }^{15}$ The applying attorney's sworn application typically would assert that, pursuant to his statutory authority, the Attorney General had specially designated an Assistant Attorney General, Will Wilson, to authorize the application and that, pursuant to that special designation, Wilson had done so. ${ }^{16}$ The applying attorney would attach as an exhibit to the application a copy of a letter addressed to him from the Justice Department and bearing what purported to be Will Wilson's signature. The letter would assert that Wilson had personally reviewed the

Florida conducted a full evidentiary hearing on the Title III authorization procedures employed in several cases from that district and from the Northern District of Georgia. United States v. Robinson, 359 F. Supp. 52, 53-54 (S.D. Fla. 1973). At that hearing (the Marder hearing), see United States v. Marder, 362 F. Supp. 484 (S.D. Fla. 1973), rev'd, 496 F.2d 1405 (5th Cir. 1974), several high-ranking officials or exofficials of the Department, including former Attorney General John N. Mitchell, testified. Mitchell testified that he had refused to authorize Title III applications in some cases, but did not recall how many. Record at 105-06, United States v. Marder, 362 F. Supp. 484 (S.D. Fla. 1973) [hereinafter cited as Marder Record]. Henry E. Petersen, a Deputy Assistant Attorney General of the Criminal Division of the Justice Department during Mitchell's administration and the person most intimately involved with the authorization procedure, testified that to the best of his recollection the Attorney General refused to authorize between two and ten Title III applications during his tenure in office (January 21, 1969, to March 1, 1972). Id. 156, 202-05.

${ }^{15}$ See United States v. Vasquez, 348 F. Supp. 532, 534 (C.D. Cal. 1972). The Justice Department standardized its Title III procedures over a period of time, although the procedures employed were substantially the same in each case. Marder Record, supra note 14, at 43, 161-63. Much of the procedure is described in U.S. Dep't of Justice, Manual for Conduct of Electronic Surveillance Under Title III of Public Law 90-351 (1970). as follows:

${ }^{16}$ The pertinent provisions of a typical Title III wiretap application would read

Pursuant to the powers conferred on him by Section 2516 of Title 18, United States Code, the Attorney General of the United States, the Honorable John N. Mitchell, has specially designated the Assistant Attorney General for the Criminal Division of the United States Department of Justice, the Honorable Will Wilson, to authorize affiant to make this application for an order authorizing the interception of wire communications. The letter of authorization signed by the Assistant Attorney General is attached to this application as Exhibit A.

United States v. Ceraso, 467 F.2d 647, 650 (3d Cir. 1972). See also United States v. Chavez, 416 U.S. 562, $582-83$ n.2 (1974) (opinion of Douglas, J.); United States v. Consiglio, 342 F. Supp. 556, 557 (D. Conn. 1972); Focarile, 340 F. Supp. at 1059. 
facts and circumstances involved in the case and had concluded that the statutory requirements for a Title III order had been satisfied. The letter would conclude as follows: "Accordingly, you are hereby authorized, under the power specially delegated to me in this proceeding by the Attorney General . . . to make application to a judge of competent jurisdiction for an order . ..."17

In addition, some Title III applications would include a second exhibit, a copy of a memorandum from the Attorney

${ }^{17}$ A typical letter of authorization reads as follows:

This is in regard to your request for authorization to make application pursuant to the provisions of $\S 2518$ of Title 18, United States Code, for an order of the court authorizing the Federal Bureau of Narcotics and Dangerous Drugs to intercept wire communications....

I have reviewed your request and the facts and circumstances detailed therein and have determined that probable cause exists to believe that Nicholas Giordina [sic] and others as yet unknown have committed, are committing, or are about to commit offenses .... I have further determined that there exists probable cause to believe the above person makes use of the described facility in connection with those offenses, that wire communications concerning the offenses will be intercepted, and that normal investigative techniques reasonably appear to be unlikely to succeed if tried.

Accordingly, you are hereby authorized under the power specially delegated to me in this proceeding by the Attorney General of the United States, the Honorable John N. Mitchell, pursuant to the power conferred on him by $\$ 2516$ of Title 18, United States Code, to make application to a judge of competent jurisdiction for an order of the court pursuant to $\S 2518$ of Title 18, United States Code, authorizing the Federal Bureau of Narcotics and Dangerous Drugs to intercept wire communications from the facility described above, for a period of 21 days.

Focarile, 340 F. Supp. at 1059; see United States v. Chavez, 416 U.S. 562, 582-83 n.2 (opinion of Douglas, J.); United States v. King, 478 F.2d 494, 499-500, (9th Cir.), cert. denied, 414 U.S. 846 (1973); United States v. Bowdach, 366 F. Supp. 1368, 1375-76 (S.D. Fla. 1973); United States v. Stanley, 360 F. Supp. 1112, 1114 (N.D. Ga. 1973).

The Department of Justice employed this form letter from the time it first began using the Title III procedure until the spring of 1972, when it changed its internal forms and the applicable language in Title III applications and proposed court orders "to reflect the new practice, i.e., to show that it was the Attorney General and not the Assistant Attorney General who had given the approval." Brief for Petitioner at 9, United States v. Giordano, 416 U.S. 505 (1974) [hereinafter cited as Giordano Brief].

In its Giordano brief the government asserted that the Justice Department employed the form letter in compliance with $\$ 1.5$ of its Manual for Conduct of Electronic Surveillance Under Title III of Public Law 90-351. Id. 7 n.5. Section 1.5 of the Manual reads as follows:

Manner in which authorization will be given. A letter over the signature of the Attorney General or of the specially designated Assistant Attorney General will authorize the person named in the request for authorization . . . to apply for the interception order. The applicant should usually be the supervising attorney, and when it is requested that an agent rather than the attorney make the application, the reason for that request should be specifically set out. 
General to Assistant Attorney General Wilson. ${ }^{18}$ The memorandum would describe its subject as "Interception Order Authorization" and would bear the handwritten initials "JNM." Like the other government documents, these memoranda followed a common form. ${ }^{19}$ They would refer to a recommendation by the Assistant Attorney General that the application in question be authorized and then would state: "Pursuant to the powers conferred on me by Section 2516 of Title 18, United States Code, you are hereby specially designated to exercise those powers for the purpose of authorizing ... the above-described application." 20

On the basis of these documents and the sworn representations of the applying attorney, the federal judge would sign the government's proposed order. In every case that order would include a finding that, having been specially designated by the Attorney General, Assistant Attorney General Will

${ }^{18}$ See, e.g., United States v. Consiglio, 342 F. Supp. 556, 559 n.3 (D. Conn. 1972); United States v. La Gorga, 336 F. Supp. 190, 194-95 (W.D. Pa. I971), modified, 340 F. Supp. 1397 (W.D. Pa. 1972).

${ }_{19}$ The special unit within the Criminal Division of the Justice Department which initially reviewed all requests for authorization to seek a Title III order also prepared the form memorandum and the "Will Wilson" letter in each case for the use of senior officials. Marder Record, supra note 14, at 164, 180.

${ }^{20}$ A typical memorandum reads in full as follows:

UNITED STATES GOVERNMENT DEPARTMENT OF JUSTICE

MEMORANDUM

TO: Will Wilson

DATE: Aug. 19, 1970

Assistant Attorney General

Criminal Division

JNM:DEH:Irt

FROM: John N. Mitchell Attorney General

SUBJECT: Interception Order Authorization

This is with regard to your recommendation that authorization be given

to Charles T. Erion, Assistant United States Attorney, Middle District of Georgia, to make application for an interception order under 18 U.S.C. 2518, permitting the interception of wire communications for a fifteen (15) day period to and from telephone numbers 912-746-9110, 912-745-2843, 912-7462844, and 912-745-2845, listed to the Sportsman's Club, 222 Third Street, Macon, Georgia, in connection with the investigation into possible violations of 18 U.S.C. 1084, 1952, and 371, by Billy C. Doolittle and others as yet unknown.

Pursuant to the powers conferred on me by Section 2516 of Title 18, United States Code, you are hereby specially designated to exercise those powers for the purpose of authorizing Charles T. Erion to make the abovedescribed application.

United States v. Doolittle, 341 F. Supp. 163, 170 (M.D. Ga. 1972); see United States v. Chavez, 416 U.S. 562, 582 n.I (opinion of Douglas, J.); United States v. Bowdach, 366 F. Supp. 1368, 1375 (S.D. Fla. 1973); United States v. Vasquez, 348 F. Supp. 532, 535 (C.D. Cal. 1972). 
Wilson had authorized the application in accordance with the statute. ${ }^{21}$

The standardized forms which the government used for its Title III applications, its attached exhibits, and its proposed court orders clearly appeared to conform to the statutory requirements regarding authorization. ${ }^{22}$ Consequently, few defense attorneys contested the validity of the authorization process in the first cases arising under Title III. ${ }^{23}$ In the last months of 1971, however, the Justice Department was forced to disclose that the authorization procedure actually employed was quite different from that described in the documents submitted to the issuing courts, deviating from the statutory requirements in various respects. ${ }^{24}$ In particular, the government disclosed that Will Wilson, the Assistant Attorney General identified as the authorizing officer in the federal Title III applications, had, in fact, done nothing. ${ }^{25} \mathrm{He}$ had reviewed no

${ }^{21}$ Title III orders submitted by government attorneys to issuing judges before the spring of 1972 included a provision that the order was issued

[p]ursuant to application authorized by the Assistant Attorney General for the Criminal Division of the United States Department of Justice, the Honorable Will Wilson, who has been specially designated in this proceeding by the Attorney General of the United States, the Honorable John N. Mitchell, to exercise the power conferred on him by $\$ 2516$ of Title 18, United States Code....

Focarile, 340 F. Supp. at 1060; see also United States v. Chavez, 416 U.S. 562, 574 n.5 (1974); United States v. Ceraso, 467 F.2d 647, 650 (3d Cir. 1972); United States v. Stanley, 360 F. Supp. 1112, $1114-15$ (N.D. Ga. 1973).

${ }^{22}$ See United States v. King, 478 F.2d 494, 499-502 (9th Cir.), cert. denied, 414 U.S. 846 (1973); United States v. Stanley, 360 F. Supp. 1112, 1113-16 (N.D. Ga. 1973) (government's documents created the "unmistakable impression" that Mitchell specially designated Wilson, who authorized the application).

${ }^{23}$ In the earliest cases arising under Title III, defense attorneys usually challenged the constitutionality of the statute and contested the sufficiency of the factual showing on the basis of which the court had issued the interception order. See, e.g., United States v. Perillo, 333 F. Supp. 914 (D. Del. 1971); United States v. Sklaroff, 323 F. Supp. 296 (S.D. Fla. 1971); United States v. Escander, 319 F. Supp. 295 (S.D. Fla. 1970). In a different prosecution of Sklaroff, counsel challenged certain claimed deficiencies in the documentation of the authorization process. See United States v. Sklaroff, 360 F. Supp. 353, 356 (N.D. Ga. 1973). See also United States v. Cantor, 328 F. Supp. 561 (E.D. Pa. 1971), affd, 470 F.2d 890 (3d Cir. 1972).

${ }^{21}$ The government was ultimately forced to disclose the true nature of its authorization procedures because on the first day of a criminal trial involving Title III evidence a defense attorney, James J. Hogan, Esq., of Miami Beach, Florida, discovered that the "Will Wilson" signatures on different letters of authorization varied remarkably. United States v. Sklaroff, 360 F. Supp. 353, 358 (N.D. Ga. 1973). See also Trme, Mar. 27, 1972, at 34 .

${ }^{25}$ United States v. Chavez, 416 U.S. 562, 567 (1974); see, e.g., United States v. Cox, 462 F.2d 1293, 1298 n.5 (8th Cir. 1972), cert. denied, 417 U.S. 918 (1974) ("Will Wilson did not examine either file or expressly authorize either application."); United 
files and had signed no letters. He had simply instructed two deputies to prepare letters of authorization and to sign his name as a routine matter in those cases in which the Attorney General's office forwarded a Title III application and an initialed memorandum. ${ }^{26}$

These disclosures prompted a flood of suppression motions by indicted defendants who contended that, because the Justice Department had improperly authorized the Title III applications and had misrepresented the identity of the authorizing officer, the subsequent interceptions were unlawful. ${ }^{27}$ But the wholesale suppression of Title III interceptions did not follow, because many lower courts accepted a series of government arguments which transformed the straightforward require-

States v. Consiglio, 342 F. Supp. 556, 558 (D. Conn. 1972) (Wilson did not authorize Title III applications or sign letters of authorization); United States v. Narducci, 341 F. Supp. 1107, 1109, 1112-13 (E.D. Pa. 1972); United States v. Baldassari, 338 F. Supp. 904, 906-07 (M.D. Pa. 1972).

At the Marder evidentiary hearing, see note 14 supra, government witnesses testified that Wilson occasionally did participate in authorization deliberations and, in fact, had signed a few letters of authorization in 1969. See note 169 infra. However, in its brief to the Supreme Court, the government described its standard procedure as one in which a Deputy Assistant Attorney General, not Assistant Attorney General Wilson, decided whether to recommend approval on behalf of the Criminal Division. Giordano Brief, supra note 17 , at 5 .

${ }^{26}$ See United States v. Cox, 462 F.2d 1293, 1298 n.5 (8th Cir. 1972), cert. denied, 417 U.S. 918 (1974) (affidavit of Henry E. Petersen); United States v. Narducci, 341 F. Supp. 1107, 1112-13 (E.D. Pa. 1972) (affidavits of Henry E. Petersen and Will Wilson); see also Appendix at 85-86, 89-90, United States v. Chavez, 416 U.S. 562 (1974) (affidavits of Harold P. Shapiro and Henry E. Petersen). In fact, however, the authorization to sign Wilson's name was even broader than that suggested. Wilson, Petersen, and Shapiro all testified at the Marder hearing that Wilson had orally authorized his Deputies to sign his name to any document which involved routine administrative matters not requiring a deviation from policy. Marder Record, supra note 14, at 137, 148-50, 258, 263, 277. Furthermore, Petersen and Shapiro would decide in such cases whether Wilson's personal consideration was necessary. Id. 263.

${ }^{27}$ Because of the timing of the government's disclosures, some defendants technically had waived the right to raise the issue by previously standing trial or by entering a plea of guilty. Nevertheless, the courts did not refuse to consider the issue on the merits in such cases. See, e.g., United States v. Pisacano, 459 F.2d 259, 260-61 (2d Cir. 1972), vacated, 417 U.S. 903 (1974); United States v. Robinson, 468 F.2d 189, 190-91 (5th Gir. 1972), remanded, 472 F.2d 973 (5th Cir. 1973) (en banc). But see United States v. Wright, 466 F.2d 1256, 1259 (2d Cir. 1972), cert. denied, 410 U.S. 916 (1973). Furthermore, in cases in which the Title III evidence would clearly result in convictions if admissible, some courts permitted defendants to enter pleas of guilty subject to appellate review of the orders denying the motions to suppress. See, e.g., United States v. Roberts, 477 F.2d 57 (7th Cir. 1973), cert. denied, 417 U.S. 908 (1974). The courts of appeals have differed concerning the propriety of this highly practical procedure. Compare Mann v. Smith, 488 F.2d 245 (9th Cir. 1973), cert. denied, 415 U.S. 932 (1974); United States v. Mizell, 488 F.2d 97 (5th Cir. 1973); and United States v. Sepe, 468 F.2d 1044 (5th Cir. 1973), with United States v. Rothberg, 480 F.2d 534 (2d Cir.), cert. denied, 414 U.S. 856 (1973). 
ments of the authorization statute into what one court called an " 'Alice-in-Wonderland' world."28

Eventually, the issues raised by the government's disclosures reached the United States Supreme Court. On May 13, 1974, the Court announced its decision in United States v. Giordano ${ }^{29}$ and United States $v$. Chavez, ${ }^{30}$ both government appeals from lower court orders suppressing wiretap evidence obtained in violation of the authorization and identification requirements of Title III. The Court unanimously agreed that the Justice Department's procedures did not comply with the statutory requirements. ${ }^{31}$ Nevertheless, the Justices disagreed about the magnitude of the various violations and whether the statutory remedy of suppression should apply in every case. ${ }^{32}$ As a result of the Giordano decision, the Justice Department's failure to follow the statutory procedure has jeopardized sixty cases

${ }^{28}$ Giordano $I, 469$ F.2d at 524.

${ }^{29} 416$ U.S. 505 (1974), aff'g 469 F.2d 522 (4th Cir. 1972).

30 416 U.S. 562 (1974), rev'g in part 478 F.2d 512 (9th Cir. 1973). [The court of appeals opinion is cited hereinafter as Chavez $I$, and the Supreme Court opinion as Chavez $I I$.]

${ }^{31}$ Giordano II, 416 U.S. at 508 (authorizations of Title III applications by officials other than those specified in 18 U.S.C. $\$ 2516(1)$ (1970)); Chavez II, 416 U.S. at 570 (misidentification of authorizing officer contrary to 18 U.S.C. $\$ \S 2518(\mathrm{I})(\mathrm{a})$, (4)(d) (1970)).

${ }^{32}$ Justice W'hite prepared the opinions of the Court in both Giordano and Chavez. All the other Justices concurred in his conclusion that the Justice Department's deviations from Title III's authorization and identification requirements were contrary to the statute, see note 31 supra. The Chief Justice and Justices Blackmun and Rehnquist, however, joined in an opinion by Justice Powell, dissenting from the Court's holding that violations of the authorization requirement required suppression not only of the conversations intercepted pursuant to the misauthorized application, but also pursuant to subsequent orders extending the original interception order or extending an order permitting the use of a pen register device in connection with the same investigation. (A pen register is a device which records the digits of all telephone numbers called from a given telephone, see Focarile, 340 F. Supp. at 1038 n.1, 1039-40. See also note 37 infra. Justice Powell contended that because the applications for extension orders were not themselves defective in any respect and were fully supported by showings of probable cause independent of any of the evidence obtained by means of the original tainted Title III order, their fruits should not be suppressed. 416 U.S. at $\mathbf{5 5 2 - 5 3}$ (opinion of Powell, J.). He therefore dissented from that portion of Justice White's opinion which affirmed the suppression of that derivative evidence because the issuing court had granted the extension orders in reliance upon the evidence obtained by the tainted interceptions. See id. at 548-49; accord, Focarile, 340 F. Supp. at $1041,1050$.

In Chavez, by contrast, the four Giordano dissenters joined in Justice White's conclusion that although misidentifications of the authorizing officer in Title III orders violated the statute, suppression was not required. 416 U.S. at 579-80. Justice Douglas dissented to this aspect of Chavez (as well as to Giordano's construction of the suppression provision) in an opinion in which Justices Brennan, Stewart, and Marshall joined. Id. at 580-81 (opinion of Douglas, J.). 
against over 626 defendants. ${ }^{33}$ In Chavez, however, by a five-tofour vote, the Supreme Court saved the government's evidence in another ninety-nine cases against 807 additional defendants. ${ }^{34}$ The majority reversed the Chavez suppression order and remanded for further proceedings not because the government's procedures were proper, but because the Court concluded that suppression was unwarranted in the circumstances.

The key to the majority's decision in Chavez is its conclusion that Congress did not intend the statutory remedy of suppression to apply to all deviations from the statute's requirements. Part II of this Article contends that conclusion was wrong. Both the Chavez majority and the dissenters overlooked several crucial aspects of the government's case which deserve critical examination and which, if properly resolved, might well require the remedy of suppression even under the "substantial violation" rationale which the Chavez majority adopted. Part III of the Article considers whether the misrepresentations concerning authorization made under oath, but in good faith, by the applying attorney to the issuing judges constituted deliberate misrepresentations by the Justice Department as an institution, and the consequences of such a conclusion. Part IV examines two issues relating to the government's use of conclusory affidavits to "correct" the record concerning the authorization process, which lower federal courts had resolved in conflicting fashion, but which the Supreme Court chose to ignore. In order to appreciate the legal and factual context in which these various issues arose, it is first necessary to examine more closely the Justice Department's procedures and the specifics of the Court's decisions in Giordano and Chavez.

\section{Giordano and Chavez: The Authorization Procedures}

There are over fifty reported federal court decisions and a number of unreported decisions concerning the Justice Department's authorization process. Although the circumstances of these cases necessarily vary, the facts of Giordano and Chavez are typical in most important respects. ${ }^{35}$

${ }^{33} 416$ U.S. at 599.

34 Id.

${ }^{35}$ The misidentification issue decided in Chavez existed in virtually every Title III case in which the government employed its standard Title III forms prior to the 


\section{A. United States v. Giordano}

Giordano involved three related prosecutions of fourteen defendants for trafficking in narcotics. ${ }^{36}$ The government's case against each defendant depended upon wiretap and pen register evidence obtained from the telephone of one of the defendants pursuant to court orders. ${ }^{37}$ The defendants moved to suppress that evidence on the grounds commonly raised in such cases, but, presumably because the Title III applications, orders and related documents appeared to be proper on their face, the defendants did not initially challenge the validity of the authorization process. ${ }^{38}$ After the district court had complete hearings on the motions to suppress, the Fifth Circuit's decision in the first of the authorization cases, United States $v$.

spring of 1972. See Giordano Brief, supra note 17, at 4-9. Giordano represented the most common class of cases in which the Justice Department's procedures deviated from the authorization requirements of $\S 2516(1)$. In Giordano neither Assistant Attorney General Will Wilson nor the Attorney General himself authorized submission of the Title III applications to the issuing court; the Attorney General's executive assistant, Sol Lindenbaum, purported to authorize the application. See text accompanying notes 41-44 infra. Other factual variations on the authorization issue involve situations in which Lindenbaum initialed the appropriate document pursuant to the Attorney General's telephoned instructions, see United States v. Pisacano, 459 F.2d 259, 263 (2d Cir. 1972), vacated, 417 U.S. 903 (1974); United States v. Vasquez, 348 F. Supp. 532, 535 (C.D. Cal. 1972), one case in which the government argued that Lindenbaum had acted in place of the Attorney General for the purpose of specially designating Will Wilson to act, United States v. Robinson, 468 F.2d 189, 191 (5th Cir. 1972), remanded, 472 F.2d 973 (5th Cir. 1973) (en banc), and two cases in which the courts decided that both the Attorney General and an Assistant Attorney General had authorized the applications in question, United States v. Ceraso, 467 F.2d 647 (3d Cir. 1972), rev'g United States v. Leta, 332 F. Supp. 1357 (M.D. Pa. 1971); United States v. Vigi, 350 F. Supp. 1008 (E.D. Mich. 1972). It appears that Deputy Assistant Attorney General Richard Kleindienst purported to authorize applications not only after he assumed the position of Acting Attorney General, see note 10 supra, but also before, Marder Record, supra note 14, at 59, 72.

${ }^{36}$ Focarile, 340 F. Supp. at 1036.

${ }^{37}$ The issuing judge signed a Title III order dated October 16, 1970, permitting agents of the Bureau of Narcotics and Dangerous Drugs to tap Giordano's telephone and intercept his wire communications for a period of 21 days; and a 15-day extension order was signed on November 6,1970 . The issuing judge also authorized B.N.D.D. agents to attach pen register devices to Giordano's telephones by an order dated October 8, 1970, and two extension orders dated October 22 and November 6, 1970. 416 U.S. at 529-30,548-50. The court of appeals confused the dates of the pen register extension orders and the dates of the Title III orders. Compare 469 F.2d at 525 with $340 \mathrm{~F}$. Supp. at 1036.

${ }^{38}$ Before the defendants became aware of the authorization issue, they had moved to suppress the wiretap and pen register evidence on the following grounds: that the recording of a pen register constitutes an interception within the meaning of Title III, I8 U.S.C. $\S 2510(4)$ (1970); that the pen register orders did not comply with Title III's requirements; that the government's applications for wiretap and pen register orders failed to establish probable cause; that the government's applications 
Robinson, ${ }^{39}$ alerted the parties that something might be amiss. ${ }^{40}$ The district court conducted further proceedings in which the government submitted the affidavits of two Justice Department officials describing the authorization procedure employed.

The affidavit of Deputy Assistant Attorney General Henry Shapiro detailed the procedures followed in reviewing the applications and related documents before submission to the office of the Attorney General. Shapiro's affidavit indicated that, after the office of the Attorney General had "approved" the authorization request, he had caused the "Will Wilson" letters to be sent to the applying attorney. ${ }^{41}$ The affidavit did not indicate what role, if any, Will Wilson played in connection

for Title III wiretap orders failed to make the necessary showing that other investigative techniques would not succeed or would be too dangerous; that the B.N.D.D. agents failed to conduct the electronic interceptions of wire communications so as to minimize the interception of innocent communications; and that the issuing court permitted the agents to conduct their electronic surveillance for an unreasonably long period. See generally 340 F. Supp. at 1037-51.

${ }^{34} 468$ F.2d 189 (5th Cir. 1972), remanded, 472 F.2d 973 (5th Cir. 1973) (en banc).

$40340 \mathrm{~F}$. Supp. at 1051.

${ }^{41}$ Shapiro's affidavit read in full as follows:

Harold P. Shapiro, being duly sworn, deposes and says:

At the times of the events related in this affidavit, I was a Deputy Assistant Attorney General in the Criminal Division of the United States Department of Justice.

This affidavit describes the processing within the Criminal Division of the Department of Justice of two requests for authorization to make application to a Federal Court for wire interception orders. Both requests related to a certain telephone in Baltimore, Maryland, allegedly used by Nicholas Giordina or Nicholas Giordano and others.

The formal requests for authorization to apply for wire interception orders were made by the Director of the Bureau of Narcotics and Dangerous Drugs on October 15 and November 5, 1970, respectively. Prior to action on each request, the respective Departmental working file, which included copies of the proposed affidavit, application, and order, was reviewed in a special unit of the Organized Crime and Racketeering Section of the Criminal Division by an attorney whose primary function was to review the entire matter for form and substance with particular emphasis on assuring strict adherence to the required statutory, judicial and Constitutional standards. The attorney of that unit handling the requests, Philip $T$. White, reviewed the files and recommended favorable action on the requests. The files were then submitted for review to Kurt W. Muellenberg, Deputy Chief, and to William S. Lynch, Chief, Organized Crime and Racketeering Section, respectively, who recommended approval and sent them to me. I examined the files and forwarded them to the Office of the Attorney General with detailed recommendations that the authorizations be granted. As part of my examination of the files, I reviewed the letters of October 16 and November 6,1970 , to Francis S. Brocato advising him that he was authorized to present the applications to the court, initialed the file copies, and authorized their 
with the authorization requests, but the government subsequently conceded that Wilson had done nothing. ${ }^{42}$

The affidavit of the Attorney General's Executive Assistant, Sol Lindenbaum, described the manner in which the Attorney General's office approved the applying attorney's request for authorization. ${ }^{43}$ Lindenbaum stated that the Attorney General

dispatch upon approval of the request for application in the Office of the Attorney General.

Appendix at 100-01, United States v. Giordano, 416 U.S. 505 (1974).

$42340 \mathrm{~F}$. Supp. at 1052.

${ }^{43}$ Lindenbaum's affidavit read in full as follows:

Sol Lindenbaum being duly sworn deposes and says:

At the times of the acts related in this affidavit I was and I am now the Executive Assistant to the Attorney General of the United States. I assist the Attorney General in the review of various matters which require his personal attention such as opinions, interpretations, decisions of the Board of Immigration Appeals, applications for pardon and other forms of Executive clemency, antitrust complaints, contracts, agreements, and proposed offers in compromise. See Title 28, Code of Federal Regulations, Section 0.6.

The Attorney General has refrained from designating any Assistant Attorney General to authorize, without his approval, the making of an application for an order permitting the interception of wire or oral communications under Title 18, United States Code, Section 2516(1). Rather, the Attorney General has required that all requests for such authorization be referred to him for consideration. In the normal course of my duties, I review such requests and make recommendations to the Attorney General thereon. I have routinely reviewed such requests since February 1969 and, accordingly, have become familiar with the applicable statutory requirements and the actions taken by the Attorney General on such requests.

On October 16, 1970, the Criminal Division of the Department of Justice addressed to the Attorney General a request for approval of an authorization to apply for an interception order initiated by the Director of the Bureau of Narcotics and Dangerous Drugs and related to a certain telephone in Baltimore, Maryland, allegedly used by Nicholas Giordina [sic] and others. The request was accompanied by copies of the proposed affidavit, application, and order, as well as a recommendation for approval from the Criminal Division. I reviewed the submitted material and concluded that the request in this case satisfied the requirements of the statute. I also concluded, from my knowledge of the Attorney General's actions on previous cases, that he would approve the request if submitted to him. Because the Attorney General was on a trip away from Washington, D.C. I approved the request pursuant to the authorization which he had given to me to act in the circumstances and caused his initials to be placed on a memorandum to Will Wilson. The memorandum, a copy of which is attached, approved a request that authorization be given to Francis $\mathrm{S}$. Brocato to make application for an interception order.

On November 6, 1970 the Attorney General approved a request that authorization be given to Francis S. Brocato to make application for an order continuing the interception on the telephone in Baltimore, Maryland, allegedly used by Nicholas Giordano and others. Attached is a copy of the Attorney General's personally initialed memorandum of that date to Will Wilson reflecting his favorable action on the request.

Appendix at 96-97, United States v. Giordano, 416 U.S. 505 (1974). 
was on a trip away from Washington when the application for the initial order arrived. Under these circumstances, Lindenbaum himself reviewed the application and decided from his "knowledge of the Attorney General's actions on previous cases, that he would approve the request if submitted to him."44 Therefore, pursuant to the Attorney General's instructions for such cases, Lindenbaum placed the Attorney General's initials on the form memorandum addressed to Will Wilson and returned it to Wilson's office, where it came to Shapiro's attention.

In the light of these affidavits the district court suppressed the wiretap evidence, because the government's misrepresentations concerning the identity of the authorizing officer had resulted in a misidentification of that officer in the Title III order in violation of the provisions of the statute. ${ }^{45}$ The court of appeals questioned the district court's rationale, ${ }^{46}$ but

${ }^{44}$ Id. 97. The affidavits of John N. Mitchell and Sol Lindenbaum which the government filed in various authorization cases do not detail the criteria on the basis of which Lindenbaum determined that the Attorney General would or would not approve a given application. They simply assert that because Lindenbaum reviewed all requests for authorization before the Attorney General acted upon them and because he was familiar with the statutory requirements and with the Attorney General's policies and decisions in Title III cases, the Attorney General orally authorized Lindenbaum to approve applications when the Attorney General was unavailable. See, e.g., United States v. King, 478 F.2d 494, 500-02 (9th Cir.), cert. denied, 414 U.S. 846 (1973); United States v. Robinson, 472 F.2d 973, 978-79 (5th Cir. 1973); United States v. Ceraso, 467 F.2d 647, 650-51 n.7 (3d Cir. 1972); United States v. Narducci, 341 F. Supp. 1107, $1111-12$ (E.D. Pa. 1972).

At the Marder evidentiary hearing both former Attorney General John N. Mitchell and Sol Lindenbaum testified concerning the circumstances under which Mitchell had authorized Lindenbaum to act. There were significant inconsistencies in the testimony of the two witnesses. Mitchell repeatedly asserted that Lindenbaum was only authorized to act in those cases in which Mitchell was outside of the United States; in all other cases Lindenbaum was instructed to consult with Mitchell by telephone before taking any action. Marder Record, supra note 14, at 46-47, 54-55, $57-58,64-66,74-75,78-80$. Lindenbaum asserted that his authority to act independently was not limited to situations in which Mitchell was abroad, but existed in any situation in which the Attorney General was "unavailable." Id. 215-16, 235, 237-38. See also Giordano Brief, supra note 17, at 12-16. Mitchell and Lindenbaum did agree, however, that on November 20, 1971, the Attorney General withdrew his authorization to Lindenbaum to approve applications on the Attorney General's behalf.

$45340 \mathrm{~F}$. Supp. at 1059.

46 The court of appeals rejected a proposition which the district court had assumed to be true for the purpose of its decision: that authorization by Lindenbaum satisfied the statute. 469 F.2d at 529-30; 340 F. Supp. at 1059. The court of appeals questioned the grounds of the district court's decision, commenting, "Perhaps it can plausibly be argued that when an application is properly authorized and only the identity of the source is mistakenly transmitted to the judge, he would have authorized the wiretap had he known the real facts." $469 \mathrm{~F} .2 \mathrm{~d}$ at 530 . In a later deci- 
affirmed the suppression order because neither the Attorney General nor any specially designated Assistant Attorney General had personally authorized the application as Title III required. ${ }^{47}$ The government then sought Supreme Court review, relying on three basic arguments which it had previously employed in the lower courts in most Title III cases involving Sol Lindenbaum.

First, the government made no claim that, by signing Will Wilson's name to a letter of authorization and by sending that letter to an applying attorney, Wilson's deputies could effectively authorize a Title III application within the meaning of the statute. ${ }^{48}$ Rather, the government characterized those functions as simply ministerial acts. ${ }^{49}$ The government claimed that despite the representations in the various Title III documents submitted to issuing judges to the contrary, the Attorney General had never "specially designated" Will Wilson to perform the discretionary act of authorization which Title III required. ${ }^{50} \mathrm{He}$ had always reserved that power to himself. According to the government, the discretionary act of authori-

sion a different panel of the same court of appeals refused to suppress Title III evidence under circumstances similar to those assumed to exist in Focarile. United States v. Bobo, 477 F.2d 974, 984-85 (4th Cir. 1973); accord, United States v. Askins, 351 F. Supp. 408, 412-13 (D. Md. 1972) (limiting Focarile). However, the Bobo decision may be distinguishable because the court of appeals concluded that "[ $[\mathrm{t}] \mathrm{he}$ fact that Mitchell himself had approved the request was made known to the judge to whom the application was made." 477 F.2d at 985 . See United States v. Stanley, 360 F. Supp. 1112 , 1118 n.13 (N.D. Ga. 1973).

47469 F.2d at 530.

${ }^{48}$ See Giordano Brief, supra note 17, at 6-8.

49 Petitioner's Brief for Certiorari at 5, United States v. Giordano, 416 U.S. 505 (1974); Giordano Brief, supra note 17, at $71 \mathrm{n.55}$; $f$. affidavit of Harold Shapiro, supra note 41 . The lower courts generally adopted the government's characterization of these actions by Wilson's two deputies, e.g., United States v. Ceraso, 467 F.2d 647, 649, 651 (3d Cir. 1972); United States v. Cox, 462 F.2d 1293, 1300 (8th Cir. 1972), cert. denied, 417 U.S. 918 (1974); United States v. Pisacano, 459 F.2d 259, 263 (2d Cir. 1972), vacated, 417 U.S. 903 (1974). But see United States v. Narducci, 341 F. Supp. 1107,1113 n.9 (E.D. Pa. 1972).

${ }^{50}$ Petitioner's Brief for Certiorari at 9-10, United States v. Giordano, 416 U.S. 505 (1974). Many of the affidavits of John N. Mitchell which the government filed in different authorization cases, see Giordano Brief, supra note 17 , at 10 n.8, made the same assertion. For example, the Mitchell affidavit filed in United States v. King, 478 F.2d 494 (9th Cir.), cert. denied, 414 U.S. 846 (1973), read in part as follows:

Although 18 U.S.C. 2516(1) permitted me, as Attorney General, to designate an Assistant Attorney General to authorize applications for wire interceptions without my approval, I chose not to make such designation, but rather to require that all requests for authority to file such applications be forwarded to me for consideration. This procedure was intended to centralize in me the responsibility for and control of the policies to be followed by the De- 
zation occurred when the Attorney General initialed the form memorandum addressed to Will Wilson. ${ }^{51}$

Second, the government contended that when the Attorney General's Executive Assistant placed the Attorney General's initials on that form memorandum on the Attorney General's behalf and pursuant to his general instructions, the Executive Assistant's action constituted adequate compliance with Title III's authorization requirements to satisfy the statute. ${ }^{52}$ The government asserted that the applicable provision of Title III, section 2516(1), ${ }^{53}$ permitted delegation of the authorization function so long as the Attorney General remained ultimately responsible for the act of approval. ${ }^{54}$ The government relied

partment of Justice in relation to Title III of the Omnibus Crime Control and Safe Streets Act of 1968.

All requests received in my office are reviewed by my Executive Assistant, Sol Lindenbaum. Except as otherwise indicated herein, Mr. Lindenbaum transmits the request and all accompanying papers to me, along with his recommendation. If I determine to approve a request, I indicate my approval by initialling a memorandum addressed to the Assistant Attorney General in charge of the Criminal Division. This memorandum recites that the Assistant Attorney General is "specially designated" to authorize the application. Upon receipt of my memorandum, a letter of authorization, over the name of the Assistant Attorney General is dispatched to the Applicant. The memorandum and the letter of authorization are part of the procedure developed for transmittal of my approval to the applicant. The memorandum constitutes a notification to the Assistant Attorney General of the Criminal Division that I have performed the discretionary act of approving the request. Id. at 500 .

${ }^{51}$ Giordano Brief, supra note 17, at 5-7; see affidavit of John N. Mitchell, supra note 50. The government's claim that the Attorney General personally authorized Title III applications when his initials were placed on the form memorandum addressed to Will Wilson is inconsistent with the text of that memorandum and with the other Title III documents, especially the Will Wilson letter. See notes 216-17 infra \& accompanying text. However, the government sidestepped the question of inconsistency by justifying the Will Wilson letter as a necessary compliance with the Justice Department's own wiretap manual. Giordano Brief, supra note 17, at 5.

${ }^{52}$ Giordano Brief, supra note 17 , at 52-65. One district court described the position of Executive Assistant as follows:

The Executive Assistant to the Attorney General is not an office created by statute as is the Deputy Attorney General or the nine Assistant Attorneys General who are appointed by the President by and with the advice and consent of the Senate, to assist the Attorney General in the performance of his duties, 28 U.S.C. $\S \S 504,506$. Rather it is a post established in the Dept. of Justice by administrative regulation to assist the Attorney General in various matters submitted for the Attorney General's action and perform such other duties and functions as may be specially assigned from time to time by the Attorney General. 28 C.F.R. I 0.6.

United States v. Cihal, 336 F. Supp. 261, 263 n.l (W.D. Pa. 1972).

${ }^{53}$ See note 6 supra.

${ }^{54}$ Petitioner's Brief for Certiorari at 9-11, United States v. Giordano, 416 U.S. 505 (1974); Giordano Brief, supra note 17, at 54-55, 61-62, 64-65. 
upon the language of various statutes which either permitted the delegation of responsibilities vested in the Attorney Gen$\mathrm{eral}^{55}$ or which prohibited such delegation in terms not employed in the Title III provision. ${ }^{56}$ In particular, the government contended that Congress only intended the Attorney General to establish the appropriate policies for the use of Title III and to make certain those policies were properly applied in individual cases, but not necessarily to make each authorization decision personally. ${ }^{57}$

These arguments had achieved little success in the lower courts. ${ }^{58}$ Consequently, before the Supreme Court, the government placed the greatest emphasis upon its final argument:

ss Giordano Brief, supra note 17, at 60-61. For example, 28 U.S.C. $\S 510$ (1970) provides:

The Attorney General may from time to time make such provisions as he considers appropriate authorizing the performance by any other officer, employee, or agency of the Department of Justice of any function of the Attorney General.

Congress adopted $\S 510$ at the same time that it adopted another provision, id. $\S 509$, which vested most of the responsibilities of the Department of Justice in the Attorney General personally.

${ }^{56}$ Giordano Brief, supra note 17, at 57 (citing 18 U.S.C. § 245(a)(1) (1970)).

57 Giordano Brief, supra note 17 , at 52-57.

${ }^{58}$ The lower courts generally rejected the government's arguments concerning authorization by the Attorney General's Executive Assistant, and suppressed electronic interceptions obtained pursuant to court orders whose applications had been approved by neither the Attorney General nor a specially designated Assistant Attorney General, e.g., United States v. Mantello, 478 F.2d 671 (D.C. Cir. 1973), cert. denied, 417 U.S. 920 (1974); United States v. King, 478 F.2d 494 (9th Cir.), cert. denied, 414 U.S. 846 (1973); United States v. Roberts, 477 F.2d 57 (7th Cir. 1973), cert. denied, 417 U.S. 908 (1974); United States v. Robinson, 468 F.2d 189 (5th Cir. 1972), remanded, 472 F.2d 973 (5th Cir. 1973 (en banc). Contra, United States v. Pisacano, 459 F.2d 259 (2d Cir. 1972), vacated, 417 U.S. 903 (1974).

The lower courts rejected the government's argument that 28 U.S.C. $\$ 510$ (1970) permitted the Attorney General to delegate his authorization functions under Title III to his Executive Assistant on a variety of grounds. The proposed construction, for example, would make the explicit "special designation" of the more recently enacted Title III provision mere surplusage. United States v. Robinson, supra at 191-92. Furthermore, Title III's specific terms and precise enumeration of who could perform the authorization function required the exclusion by implication of all other, unmentioned officials. United States v. Aquino, 338 F. Supp. 1080, 1082-83 (E.D. Mich. 1972).

The government also argued in the lower courts that when Executive Assistant Sol Lindenbaum approved Title III applications on the Attorney General's behalf, he had simply acted as the Attorney General's "alter ego," whose act should be attributed to the Attorney General himself. Giordano I, 469 F.2d at 526. See also United States v. King, supra at 503-04; United States v. Narducci, 341 F. Supp. 1107, 1114 (E.D. Pa. 1972). With one major exception, the courts of appeals which considered the issue also rejected the "alter ego" argument. They generally concluded that Congress intended an official identified in $\$ 2516(1)$ to give "personal attention" to the authorization of Title III applications. Giordano I, 469 F.2d at 529; United States v. 
that even if its authorization procedures had not strictly complied with Title III's requirements, the Court should not impose the drastic remedy of suppression. ${ }^{59}$ The government characterized the authorization process as a matter of internal procedure unrelated to the privacy interests of persons subjected to electronic surveillance, ${ }^{60}$ and argued that the specific language of Title III's statutory suppression sanction did not apply to

Narducci, supra at 114-15. See United States v. Robinson, supra at 192. The lower courts also rejected the "alter ego" argument because, in principle at least, it would permit not only the Executive Assistant, but any other person in whom the Attorney General placed his confidence to perform functions which Congress assigned to the Attorney General himself. To condone such a practice might encourage further laxity. United States v. Narducci, supra at 1115 . Furthermore, as the court of appeals noted in Giordano, such a practice would also permit the Attorney General to evade his responsibilities at will simply by repudiating the actions of a purported alter ego when those actions proved to be improper or politically embarrassing. 469 F.2d at 528-29.

Despite these deficiencies, the government did persuade one panel of the Second Circuit that the Justice Department's procedures satisfied $\S 2516(1)$ even when the Attorney General did not personally participate in the authorization process. United States v. Pisacano, supra. The Pisacano court felt Title III was satisfied because the Attorney General had assumed full responsibility for what had been done. Id. at 263. Indeed, the court even concluded that the action by the Executive Assistant satisfied the letter of $\$ 2516(1)$. If Congress had wanted to preclude the Attorney General from delegating the function of authorization to his Executive Assistant, stated the court, it could have included an express prohibition in the authorization provision. Id. at 263-64.

As the Supreme Court noted in its Giordano opinion, no lower court has adopted Pisacano's rationale, although other panels of that court of appeals and subordinate district courts have followed the ruling as a matter of precedent. 416 U.S. at 511-12 n.3. Furthermore, those other Second Circuit panels and subordinate district courts have criticized the Justice Department's procedures even while condoning them, at least in a functional sense. United States v. Fiorella, 468 F.2d 688, 691 (2d Cir. 1972), cert. denied, 417 U.S. 917 (1974); United States v. Becker, 461 F.2d 230, 236 (2d Cir. 1972), vacated, 417 U.S. 903 (1974); see United States v. Consiglio, 342 F. Supp. 556, 559 (D. Conn. 1972).

${ }^{59}$ Giordano Brief, supra note 17 , at $29-51$. The court of appeals in Giordano rejected this argument as "a beautiful example of the bootstrap technique." 469 F.2d at 531. See also United States v. Wierzbicki, 12 CRIM. L. REP. 2075 (E.D. Mich. 1972); United States v. Narducci, 341 F. Supp. 1107, $1116-17$ (E.D. Pa. 1972); United States v. Cihal, 336 F. Supp. 261, 267 (W.D. Pa. 1972).

${ }^{60}$ Giordano Brief, supra note 17 , at $33-36$. The government asserted that Congress enacted Title III's statutory suppression sanction, 18 U.S.C. $\$ 2518(10)$ (a) (1970), in order to codify existing search and seizure law, not to create additional grounds for whose violation courts should suppress otherwise admissible evidence. The government argued that the action of the issuing judge in reviewing the sworn application for an interception order and in making the necessary findings of necessity and probable cause completely satisfied the fourth amendment's requirements. Giordano Brief, supra note 17, at 30-33, 43-44. According to the government, Title IIl's authorization requirements were not intended to protect the rights of any individual, but to assure Congress and the public as a whole that the Justice Department was centralizing its policies regarding electronic interceptions as the Congress intended. Id. $53,55-57,71$. 
violations of the authorization requirements. ${ }^{61}$

The Supreme Court found the government's arguments concerning Lindenbaum's actions unpersuasive. ${ }^{62}$ Noting that Congress had imposed "important preconditions" to securing a Title III court order in order to be certain that the statutory authority to conduct electronic surveillances would be used with restraint, the Court described the authorization requirement of section 2516(1) as a "critical precondition" intended to assure the "mature judgment of a particular, responsible Department of Justice official." 63 The Court unanimously rejected the government's delegation arguments because the language of section 2516(1) explicitly identified Assistant Attorneys General as the only Justice Department officials to whom the Attorney General could assign the authorization function. ${ }^{64}$

Nevertheless, from the government's point of view, Giordano was not a total failure; despite section 2515 of Title III, which prohibits the reception into evidence of any improperly intercepted communication, ${ }^{65}$ five members of the Court adopted the government's view that Title III's suppression did not apply to all deviations from the statute's requirements. ${ }^{66}$ infra.

${ }^{61}$ Giordano Brief, supra note 17 , at 34-39. See text accompanying notes $72-78$

62416 U.S. at $512-13$; id. at 548 (opinion of Powell, J.).

${ }^{63} \mathrm{Id}$. at 515-16.

${ }^{64}$ Id. at 514,523 ; id. at 548 (opinion of Powell, J.). The Court also rejected the government's argument that the Attorney General's delegation powers under § 2516(1) should not be narrowly confined to his Assistant Attorneys General in the light of $\S 2516(2)$, which permits state legislation to authorize the principal prosecuting officers of political subdivisions of a state to seek interception orders, see Giordano Brief, supra note 17 , at 55-57. The Court concluded that Congress obviously intended to centralize the power of seeking interception orders as much as possible, and implied that $\S 2516(2)$ had been drafted in a more permissive form to allow for individual variations in the prosecutorial structure of different states. 416 U.S. at 522-23; see S. REP., supra note 3, at 2187.

65 This section reads in full as follows:

Whenever any wire or oral communication has been intercepted, no part of the contents of such communication and no evidence derived therefrom may be received in evidence in any trial, hearing, or other proceeding in or before any court, grand jury, department, officer, agency, regulatory body, legislative committee, or other authority of the United States, a State, or a political subdivision thereof if the disclosure of that information would be in violation of this chapter.

18 U.S.C. § 2515 (1970). Another Title III provision, § 2517, affirmatively permits the disclosure of intercepted communications only if obtained "by any means authorized by this chapter."

${ }^{66} 416$ U.S. at 524-29. Most lower courts reached the conclusion that $\S 2515$ prohibits the use of any communication intercepted pursuant to a Title III court order when the application fails to conform to the statute's requirements; they recognized 
In attempting to avoid the section 2515 prohibition, the government emphasized section 2518(10)(a), which provides that any person with standing may move to suppress an intercepted communication or evidence derived therefrom on the following grounds:

(i) the communication was unlawfully intercepted; (ii) the order of authorization or approval under which it was intercepted is insufficient on its face; or (iii) the interception was not made in conformity with the order of authorization or approval. ${ }^{67}$

In Giordano, the district court suppressed the wiretap evidence under paragraph (ii) of section 2518(10)(a). The court reasoned that an order of authorization which failed to identify the authorizing officer altogether would be insufficient on its face, and that an order which misidentified the authorizing officer was similarly defective. ${ }^{68}$ The court of appeals agreed that suppression was proper pursuant to paragraph (ii), but for a different reason: that the nonauthorization of the applica-

that Congress intended to assure strict compliance, see text accompanying note 5 supra, and suppression appeared to be the obvious remedy to achieve that result. See, e.g., United States v. Stanley, 360 F. Supp. 1112, 1117 (N.D. Ga. 1973); United States v. Cihal, 336 F. Supp. 261, 267 (W.D. Pa. 1972).

${ }^{67}$ Giordano Brief, supra note 17 , at 35-39. 18 U.S.C. $\$ 2518(10)(a)$ (1970) reads in full as follows:

Any aggrieved person in any trial, hearing, or proceeding in or before any court, department, officer, agency, regulatory body, or other authority of the United States, a State, or a political subdivision thereof, may move to suppress the contents of any intercepted wire or oral communication, or evidence derived therefrom, on the grounds that-

(i) the communication was unlawfully intercepted;

(ii) the order of authorization or approval under which it was intercepted is insufficient on its face; or

(iii) the interception was not made in conformity with the order of authorization or approval.

Such motion shall be made before the trial, hearing, or proceeding unless there was no opportunity to make such motion or the person was not aware of the grounds of the motion. If the motion is granted, the contents of the intercepted wire or oral communication, or evidence derived therefrom, shall be treated as having been obtained in violation of this chapter. The judge, upon the filing of such motion by the aggrieved person, may in his discretion make available to the aggrieved person or his counsel for inspection such portions of the intercepted communication or evidence derived therefrom as the judge determines to be in the interests of justice.

Section 2510(11) defines an "aggrieved person" as "a person who was a party to any intercepted wire or oral communication or a person against whom the interception was directed."

68 $340 \mathrm{~F}$. Supp. at 1060 . 
tion by any proper officer made the resulting court order the equivalent of an order insufficient on its face. ${ }^{69}$

The Supreme Court decided that neither the improper authorization of the application nor the misidentification of the authorizing officer in the court order made that order facially insufficient. Justice White's majority opinion noted that the interception order did identify, albeit erroneously, a specially designated Assistant Attorney General as the person who had authorized the application; on its face, therefore, the court order was sufficient despite the government's subsequent disclosures. ${ }^{70}$

But the court of appeals had also concluded that the wiretap evidence was intercepted unlawfully under paragraph (i) because of "the pattern of the Government's behavior in ignoring statutory requirement after statutory requirement."71 The government sought to overcome this conclusion by construing paragraph (i) to apply only to interceptions which would violate the Constitution. ${ }^{72}$ Asserting that paragraphs (ii) and (iii) of section 2518(10)(a) mandate suppression for "purely statutory defaults without constitutional overtones," the government contended that if the phrase "unlawfully intercepted" in paragraph (i) encompassed purely statutory deviations, paragraphs (ii) and (iii) would be devoid of meaning. ${ }^{73}$ The government sought additional support for its position by quoting the legislative history of section 2518(10)(a), which suggested that the section was intended only to codify existing search and seizure law without significant expansion of the suppression remedy. ${ }^{\mathbf{7 4}}$

Justice White's opinion allowed that the government's argument had merit as a matter of statutory construction. The majority agreed that paragraphs (ii) and (iii) "must be deemed" to provide suppression under circumstances to which para-

69 469 F.2d at 531 . See note 46 supra.

70416 U.S. at 525 n. 14 .

71469 F.2d at 531 .

72 Giordano Brief, supra note 17, at 35-36. The government had also employed this argument in some lower court cases. Although one court of appeals did adopt it, In re Marcus, 491 F.2d 901, 903 (1st Cir.), vacated, 417 U.S. 942 (1974), other lower courts were unpersuaded, see United States v. Narducci, 341 F. Supp. 1107, 1116 (E.D. Pa. 1972).

73416 U.S. at 526.

${ }^{74}$ Giordano Brief, supra note 17 , at $38-39$; see S. REP., supra note 3 , at $2184-85$, 2195. 
graph (i) would not apply. ${ }^{75}$ However, the majority rejected the contention that paragraph (i) applied only to constitutional violations, holding instead that paragraph (i) would require suppression for violations of any of the statutory requirements which "directly and substantially implement the congressional intention to limit the use of intercept procedures to those situations clearly calling for the employment of this extraordinary investigative device."76 The majority identified section 2516(1), which conditions the use of intercept procedures "upon the judgment of a senior official in the Department of Justice," as a critical statutory provision. ${ }^{77}$ Relying upon the legislative history of Title III, the majority stated, "We are confident that the provision for pre-application approval was intended to play a central role in the statutory scheme and that suppression must follow when it is shown that this statutory requirement has been ignored."78

Four members of the Court disagreed with Justice White's interpretation of paragraph (i) of section 2518(10)(a), because in their view, Title III did not reflect a congressional intent to treat some statutory violations more seriously than others. ${ }^{79}$ They accused the majority of overstepping the judicial function by arrogating to the courts discretion "to pick and choose among various statutory provisions, suppressing evidence only when they determine that a provision is . . . directly and substantially' related to the congressional scheme."80 In particular, they objected to the majority's use of that discretion in Chavez.

\section{B. United States v. Chavez}

Like Giordano, Chavez was a narcotics case. ${ }^{81}$ The government had obtained critical evidence against twelve defendants as the result of two court-ordered wiretaps. The applications

75416 U.S. at 537.

${ }^{76} \mathrm{Id}$.

$7 \pi$ Id.

${ }^{78} \mathrm{Id}$. at 528 .

${ }^{79}$ Chavez II, 416 U.S. at 585-87 (opinion of Douglas, J., joined by Brennan, Marshall, and Stewart, JJ.).

${ }^{80} \mathrm{Id}$. at 584-85. In fact, some lower courts had assumed such a discretion in Title III cases involving only the misidentification of the authorizing officer, see text accompanying notes 91-98 infra, or involving the government's failure to give notice of Title III proceedings within the statutory period, see 18 U.S.C. $\$ 2518(9)$ (1970); cases cited in note 9 supra.

${ }^{81}$ Chavez $I$. 
for each wiretap order, the orders themselves, and the related documents included the usual statements that the Attorney General had specially designated Will Wilson under section 2516(1) and that, after personally reviewing the appropriate documents, Wilson had authorized the submission of the applications to the issuing judge. ${ }^{82}$

After the government notified the defendants that it intended to offer wiretap evidence at trial, ${ }^{83}$ the defendants moved to suppress, and the government filed the affidavits of various Justice Department officials to substantiate its revised version of what had actually occurred. ${ }^{84}$ As in Giordano, those affidavits indicated that Will Wilson had done nothing. Instead, his two Deputies, Henry E. Petersen and Harold Shapiro, had signed and forwarded the Will Wilson letters. ${ }^{85}$ Sol Lindenbaum's affidavit admitted that in the case of one application he had personally initialed the form memorandum addressed to Will Wilson, but stated that the Attorney General himself had performed that act in the case of the first application. ${ }^{86}$ The government also submitted the affidavit of the former Attorney General, John N. Mitchell. The affidavit asserted that Mitchell had "approved" the first authorization request and had "personally initialled [a] memorandum of that date reflecting my favorable action," and described the form memorandum as constituting notice to Wilson "that the discretionary action of approving the request to make application to the court for an interception order was taken by me." 87

The district court suppressed the wiretap evidence derived from the second application because neither the Attorney General nor a specially designated Assistant Attorney General had authorized its submission to the issuing judge; the court of appeals affirmed. ${ }^{88}$ As to the first application, however, both courts assumed, despite the defendant's contentions to the contrary, that by personally initialing the form memorandum addressed to Will Wilson the Attorney General had "personally

82416 U.S. at 566.

${ }^{83}$ See 18 U.S.C. $\$ 2518(9)(1970)$.

84416 U.S. at $565-66$.

${ }^{85}$ See affidavits of Henry E. Petersen and Harold Shapiro, Appendix at 85-86. 89-90, United States v. Chavez, 416 U.S. 562 (1974).

${ }^{86}$ The affidavit is quoted in the court of appeals' opinion, $478 \mathrm{~F} .2 \mathrm{~d}$ at 513-14.

87 The affidavit is quoted in id.

${ }^{88} I d$. at 517 (quoting the unreported district court opinion). 
approved" the authorization request. ${ }^{89}$ Nevertheless, even under these circumstances both courts ordered suppression of the fruits of the first application because the application and order did not correctly identify the authorizing officer as the Attorney General himself. ${ }^{90}$

In affirming the lower court's decision on this basis, the court of appeals recognized it was acting contrary to most other decisions. ${ }^{91}$ Most courts had held that if the Attorney General personally participated in the authorization process, the misidentification of Will Wilson as the authorizing officer would not require suppression of the electronic interceptions. ${ }^{92}$ The lower courts reached this conclusion on a variety of grounds. Some simply characterized the misidentification of the authorizing officer as "irrelevant,"93 "immaterial,"94 or at most "harmless error." 95 Other courts asserted that suppression was unwarranted because such misidentification had neither prejudiced the defendants ${ }^{96}$ nor deceived the courts in any material fashion. ${ }^{97}$ If the government had initially disclosed the true nature of the authorization process, reasoned these courts, the issuing judge would still have granted the order. ${ }^{98}$

${ }^{89} \mathrm{Id}$. at 515. This scenario was repeated in the Supreme Court. Respondent's Brief in Opposition to Granting Certiorari at 1-4, United States v. Chavez, 416 U.S. 562 (1974); Brief for the Respondent George Apodaca at 2-4, id. See also note 203 infra.

90478 F.2d at 517.

${ }^{91}$ Id. at 515-16.

${ }^{92}$ See cases cited in id. at $516 \mathrm{n} .1$ and in United States v. James, 494 F.2d 1007, 1017-18 (D.C. Cir. 1974).

${ }^{93}$ United States v. Cox, 462 F.2d 1293, 1300 (8th Cir. 1972), cert. denied, 417 U.S. 918 (1974).

${ }^{94}$ United States v. James, 494 F.2d 1007, 1017 (D.C. Cir. 1974); United States v. Doolittle, 341 F. Supp. 163, 169 (M.D. Ga. 1972).

${ }^{95}$ United States v. Becker, 461 F.2d 230, 235 (2d Cir. 1972), vacated, 417 U.S. 903 (1974); see United States v. Mainello, 345 F. Supp. 863, 880 n.65 (E.D.N.Y. 1972).

${ }^{96}$ United States v. Bowdach, 366 F. Supp. 1368, 1373 (S.D. Fla. 1973); United States v. Whitaker, 343 F. Supp. 358, 361 (E.D. Pa. 1972), rev'd on other grounds, 474 F.2d 1246 (3d Cir.), cert. denied, 412 U.S. 953 (1973); United States v. Consiglio, 342 F. Supp. 556, 560-61 (D. Conn. 1972); $c f$. United States v. Ciamacco, 362 F. Supp. 107, 113 (W.D. Pa.), aff'd, 491 F.2d 751 (3d Cir. 1973) (no prejudice to defendants because government filed affidavits giving revised version of what had occurred well in advance of trial).

${ }^{97}$ United States v. Consiglio, 342 F. Supp. 556, 560 n.6 (D. Conn. 1972); cf. United States v. Pisacano, 459 F.2d 259, 264 n.5 (2d Cir. 1972), vacated, 417 U.S. 903 (1974).

${ }^{98}$ United States v. Bowdach, 366 F. Supp. 1368, 1373-74 (S.D. Fla. 1973); United States v. Whitaker, 343 F. Supp. 358, 361 (E.D. Pa. 1972), rev'd on other grounds, 474 F.2d 1246 (3d Cir.), cert. denied, 412 U.S. 953 (1973); see Giordano I, 469 F.2d at 530, quoted in note 46 supra. 
Some lower courts also refused for policy reasons to suppress wiretap evidence on the grounds of misidentifications. They reasoned that the legislative purposes of the identification requirements were to assure the formulation and uniform application of Justice Department policy by an identifiable high-level official. ${ }^{99}$ Because they believed that the Attorney General's personal participation in the authorization process substantially satisfied those congressional purposes, they thought suppression in such circumstances would elevate "form over substance." 100 They flatly refused to construe the identification requirements of the statute so inflexibly as to require suppression in such cases. ${ }^{101}$

On the other hand, a minority of lower courts treated the misidentification of the authorizing officer as a very serious matter. ${ }^{102}$ They regarded the Title III identification require-

${ }^{99}$ United States v. Ceraso, 467 F.2d 647, 652 (3d Cir. 1972); United States v. Cox, 462 F.2d 1293, 1299-1300 (8th Cir. 1972), cert. denied, 417 U.S. 918 (1974); United States v. Pisacano, 459 F.2d 259, 263, 264 n.5 (2d Cir. 1972), vacated, 417 U.S. 903 (1974); United States v. Bowdach, 366 F. Supp. 1368, 1372-73 (S.D. Fla. 1973).

${ }^{100}$ United States v. Brick, 502 F.2d 219, 221 (8th Cir. 1974); United States v. Roberts, 477 F.2d 57, 59 (7th Cir. 1973) (dictum), cert. denied, 417 U.S. 908 (1974); United States v. Fox, 349 F. Supp. 1258, 1262 (S.D. Ill. 1972), aff'd, 500 F.2d 1404 (5th Cir. 1974); United States v. Kohne, 347 F. Supp. 1178, 1182 (W.D. Pa. 1972).

${ }^{101}$ The difficulty of reconciling refusals to suppress Title III evidence despite violations of the statute's identification requirements with the intent of Congress that Title III's provisions should be stringently applied, see text accompanying note $\mathbf{5}$ supra, produced a schizoid quality in the opinions of some courts. For example, in United States v. Roberts, 477 F.2d 57 (7th Cir. 1973), cert. denied, 417 U.S. 908 (1974), the court of appeals stated its view that when Executive Assistant Sol Lindenbaum authorized Title III applications on the Attorney General's behalf, he committed only "technical errors" for which "the drastic remedy of suppression" seemed inappropriate. Id. at 60 . Nevertheless, said the court, Congress made it perfectly clear that the suppression remedy should apply in such cases, and that the courts had no alternative but to comply. Id. On the other hand, in the same opinion, the court stated that violations of Title III's identification requirements would not mandate suppression, for excluding intercepted communications under such circumstances would elevate form over substance. Id. at 59-60 (dictum). Other courts avoided the problem of reconciliation altogether by simply ignoring the identification requirements, see, e.g., United States v. Fox, 349 F. Supp. 1258 (S.D. Ill. 1972), aff'd, 500 F.2d 1404 (5th Cir. 1974); United States v. DeCesaro, 349 F. Supp. 546 (E.D. Wis. 1972); United States v. Kohne, 347 F. Supp. 1178 (W.D. Pa. 1972), or by straining to construe the government's Title III documents in a manner consistent with its subsequent disclosures, see United States v. Ceraso, 467 F.2d 647, 652-53 (3d Cir. 1972); United States v. Vigi, 350 F. Supp. 1008, 1009-10 (E.D. Mich. 1972); $c f$. United States v. Pisacano, 459 F.2d 259, 264 n.5 (2d Cir. 1972), vacated, 417 U.S. 903 (1974) (Attorney General or his Executive Assistant was "reasonably identifiable" as the authorizing officer); United States v. Ciamacco, 362 F. Supp. 107, 113 (W.D. Pa.), aff'd, 491 F.2d 751 (3d Cir. 1973) (Title III satisfied when documents identify the Attorney General as taking some action in each particular case).

102 United States v. Brown, 351 F. Supp. 38 (W'.D.N.C. 1972). 
ments not simply as a corollary of the section 2516 authorization requirement, but as a separate safeguard of equal importance. ${ }^{103}$ Some also rejected the suggestion that because the government had disclosed the full details of the authorization process later, no substantial violations had occurred. ${ }^{104}$ In their view, Congress enacted the identification requirements to ensure that the officials who authorized Title III applications would act with circumspection. That congressional purpose would be poorly served by overlooking the government's "routinely false" representation, ${ }^{105}$ which permitted the true authorizing officer to mask his identity until long after the electronic interceptions, and to reveal it only if he chose to come forward. ${ }^{106}$ Some courts harshly criticized the Justice Department's authorization procedures as an "elaborate paper charade,"107 characterized by "ghost-written letters and patently false and misleading memoranda." 108 They could con-

${ }^{103}$ E.g., United States v. Ceraso, 467 F.2d 647, 652 (3d Cir. 1972) (dictum); United States v. Brown, 351 F. Supp. 38 (W.D.N.C. 1972); Focarile, 340 F. Supp. at 1056-57.

${ }^{104}$ Compare United States v. Ceraso, 467 F.2d 647, 652 (3d Cir. 1972) (Justice Department has readily disclosed its actual procedures whenever asked), with United States v. Vasquez, 348 F. Supp. 532, 537 (C.D. Cal. 1972) ("It hardly fulfills the expressed intent of Congress to say that the true lines of responsibility may now be traced by means of affidavits submitted almost two years later.").

${ }^{105}$ United States v. Brown, 351 F. Supp. 38, 41 (W.D.N.C. 1972).

${ }^{106}$ In contrast to those courts which concluded that the government's Title III documents did somehow properly identify the Attorney General as the authorizing officer, see cases cited in note 100 supra, other courts asserted that quite the opposite was true, see, e.g., United States v. Marder, 362 F. Supp. 484, 487 (S.D. Fla. 1973), rev'd, 496 F.2d 1405 (5th Cir. 1974); United States v. Vasquez, 348 F. Supp. 532, 537 (C.D. Cal. 1973). Indeed, some courts congratulated the former Attorney General on his "apparent candor" because only through the affidavits which admitted his participation did the courts learn who had really authorized the Title III applications. Chavez I, 478 F.2d at 517 n.2. See United States v. Marder, supra at 487. However, as Justice Douglas pointed out in his Chavez dissent, the act of the Attorney General in acknowledging his role could only improve the Justice Department's position:

It is simply not enough that Mitchell's responsibility is established only after a prosecution is underway and a motion to suppress filed. After-the-fact acceptance for the Chavez surveillance was made at no cost. The surveillance was productive and was directed against an alleged drug trafficker, a pariah of society. Accepting responsibility at this point, further, helped Mitchell and the Justice Department avoid the acute embarrassment of losing this prosecution. But this was not the scheme created by the Congress.

416 U.S. at 591 (opinion of Douglas, J.).

${ }^{107}$ Chavez I, 478 F.2d at 515; United States v. King, 478 F.2d 494, 502 (9th Cir.), cert. denied, 414 U.S. 846 (1973); United States v. Sklaroff, 362 F. Supp. 478, 483-84 (S.D. Fla. 1973), rev'd, 500 F.2d 1183 (5th Cir. 1974).

${ }^{108}$ United States v. Sklaroff, 362 F. Supp. 478, 483 (S.D. Fla. 1973), rev'd, 500 F.2d 1183 (5th Cir. 1974). 
ceive of no justification for the procedures employed except the "apparently deliberate deception of the courts by the highest law officers in the land."109

Justice White's majority opinion in Chavez rejected such criticisms. Although concluding that the Justice Department procedures did not comply with the statute's identification requirements, the majority refused to believe that deliberate deception was involved. ${ }^{110}$ They reached this conclusion because they could perceive no purpose which deception would serve; an issuing judge would be no less likely to grant a Title III order authorized by the Attorney General than one authorized by Will Wilson. ${ }^{111}$ Moreover, the majority decided that the identification requirements of the statute did not "directly and substantially implement the congressional intention to limit the use" of Title III procedures. ${ }^{112}$ Consequently, although the Justice Department's misidentification of the authorizing officer was improper, that impropriety did not fall within that limited class of violations described in Giordano to which the suppression remedy exclusively applied. ${ }^{113}$

The majority concluded that the Title III identification requirements were not "a central safeguard in preventing abuse"114 for two reasons. First, they emphasized the importance of the authorization aspect of the authorization-identification requirements, concluding that the Attorney General's personal approval of the application satisfied the fundamental congressional purpose of the regulations. ${ }^{115}$ Secondly, the majority asserted that Congress enacted the identification requirements only to facilitate performance of the issuing judge's responsibilities to determine in each case that authorization had, in fact, occurred and to report to the Administrative Office of the federal courts concerning each Title III application submitted for his consideration. ${ }^{116}$ In particular, the majority

${ }^{109}$ Chavez I, 478 F.2d at 517. See United States v. King, 478 F.2d 494, 502 (9th Cir.), cert. denied, 414 U.S. 846 (1973); United States v. Sklaroff, 362 F. Supp. 478, 483-84 (S.D. Fla. 1973), rev'd, 500 F.2d 1183 (5th Cir. 1974).

110416 U.S. at 572.

111 Id.

112 Id. at 575.

${ }^{13}$ See text accompanying notes 75-78 supra.

11416 U.S. at 571.

115 Id. at 573-78.

${ }^{116} \mathrm{Id}$. at 575-79; see 18 U.S.C. $\$ 2519$ (1970); S. REP., supra note 3, at 2196. Elsewhere in the opinion Justice White recognized that the identification requirements 
rejected the suggestion that Congress intended the identification requirements, by themselves, "to occupy a central, or even functional, role in guarding against unwarranted use of wiretapping or electronic surveillance." 117

The four dissenting Justices reached an opposite conclusion. In their view, Congress enacted the identification requirements as "a significant deterrent to reckless or needless electronic surveillance." 118 They believed that the central purpose of the authorization requirement may be defeated unless the identity of the responsible authorizing officer is fixed in the original applications and order, as Title III unequivocally requires. ${ }^{119}$ As the majority itself recognized, Congress adopted the authorization requirement of section 2516 to ensure that law enforcement agencies did not seek Title III court orders until a high level, politically accountable official had made a personal determination that electronic intrusions were justified in the circumstances of each case. ${ }^{120}$ Congress enacted the authorization requirement in order to foster a policy of restraint. ${ }^{121}$ However, if the authorizing officer can conceal his identity until he chooses to reveal it, all impetus for that policy of restraint is lost. ${ }^{122}$ Thus, Congress adopted the identification requirements as a mechanism by which to compel the

serve other purposes as well. "Requiring identification of the authorizing official in the application facilitates the court's ability to conclude that the application has been properly approved under $\S 2516$; requiring identification in the court's order also serves to 'fix responsibility' for the source of the preliminary approval." 416 U.S. at 575. Furthermore, the Court stated in Giordano, Congress intended to assure proper authorization before interceptions occurred, id. at $523 \mathrm{n} .12$. Only by enforcing the identification requirements could the Court ensure compliance with that objective. Nevertheless, Justice White felt free to discount the identification requirements largely because they were a relatively recent addition to the safeguards Congress had considered over the years and because Senate Report No. 1097, supra note 3, did not include a sufficiently elaborate statement of the purpose of the identification requirements to refute the contention that only the facilitation of the reporting requirements of $\$ 2519$ was involved. 416 U.S. at 578-79; see notes 8-9 supra.

117416 U.S. at 578.

${ }^{118}$ Id. at 594 (opinion of Douglas, J.).

${ }^{119} \mathrm{Id}$. at $595-96$.

${ }^{120}$ Giordano II, 416 U.S. at 512-13.

${ }^{121}$ Id. at $527-29$.

${ }^{122}[\mathrm{I}] \mathrm{t}$ is clear that this personal responsibility and political accountability, relied on by Congress to check the reckless use of electronic surveillance, is rendered a mere chimera when the official actually authorizing a wiretap application is not identified until years after the tap has occurred, when he might already be out of office, when the usefulness of the tap is already established, when it is clear that the surveillance was not abusive, and then only 
authorizing officer to assume personal responsibility and political accountability for an electronic intrusion before it occurred. By tolerating the Justice Department's misleading procedures and condoning the after-the-fact acknowledgement of the Attorney General's role by means of an ex post facto affidavit, concluded the dissenters, the majority undercut the whole structure of the authorization requirement.

The dissenters also rejected the majority's interpretation of section 2518(10)(a), which limited the statutory suppression sanction to those Title III requirements "directly and substantially" restricting the use of electronic surveillance techniques to clearly appropriate cases. ${ }^{123}$ Although the dissenters' discussion of section 2518(10)(a) was less than comprehensive, ${ }^{124}$ it appears that their objections were warranted. The reasons for this conclusion-stated only in part by the dissenting opinion-are the subject of Part II.

\section{The Suppression Sanction}

Section 2518(10)(a) authorizes individuals with standing in adversary proceedings to move to suppress electronically intercepted communications because the interception was unlawful, because the interception order was insufficient on its face, or because the interception did not conform to the interception order. ${ }^{125}$ The Supreme Court concluded that section $2518(10)(a)$ would require suppression in Giordano-type cases, in which Sol Lindenbaum, rather than the Attorney General, initialed the memorandum addressed to Will Wilson; but would not require suppression in cases like Chavez, in which the Attorney General personally participated but the appli-

through voluntary admissions or the sifting of potentially contradictory affidavits. Responsibility is hardly "focused," and the "lines of responsibility" are gossamer at best. This is why Congress added the demand that responsibility be immediately fixed.

Chavez II, 416 U.S. at 593-94 (opinion of Douglas, J.).

${ }^{123} \mathrm{Id}$. at $584-85$.

124 The dissenters discounted the legislative history of Title III and emphasized that the text of the statute contained no provision permitting the courts to distinguish between "central safeguards" and other Title III requirements which were less than central. $C f$. United States v. Robinson, 472 F.2d 973, 978 (5th Cir. 1973) (en banc) (Clark, J., dissenting) ("[T]he law being unambiguous, resort to legislative history is inappropriate.").

${ }^{125}$ See text accompanying note 67 supra. 
cation and order misidentified Will Wilson as the authorizing officer. ${ }^{126}$

The difficulty with the majority position is that it denigrated the importance of section 2515, which flatly prohibits the use or derivative use of intercepted communications "if the disclosure of that information would be in violation of this chapter."127 In Gelbard v. United States, the Court stated that "[t]he unequivocal language of $\S 2515$ expresses the fundamental policy adopted by Congress on the subject of wiretapping and electronic surveillance ... strictly to limit the employment of those techniques of acquiring information."128 Title III permits electronic interceptions only pursuant to a section 2516 authorization and to a court order, which a judge "may grant in conformity with Section 2518."129 Section 2518 includes a detailed procedure for authorizing electronic interceptions. Among other things, it describes the specific information a sworn application must include, the explicit findings the issuing judge must make before granting an interception order, and the restrictions and limitations such an order should contain. ${ }^{130}$ In Gelbard the Court stated that Congress intended to permit the interception and disclosure of private communications only upon compliance with these "stringent conditions" and that section 2515 was central to the entire legislative scheme. ${ }^{131}$

But in Giordano the Supreme Court majority barely mentioned section 2515's evidentiary prohibition, asserting instead that section 2518(10)(a) would govern "what disclosures are forbidden, and are subject to motions to suppress."132 Thus, section 2515's reference to all disclosures which "would be in violation of this chapter" was effectively narrowed to only those

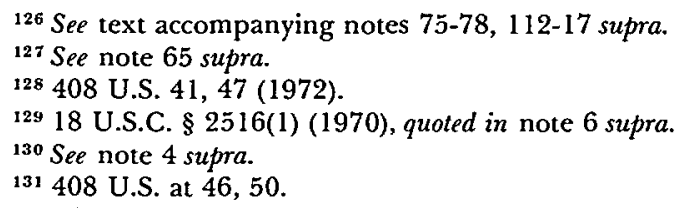

Section 2515 provides that no part of the contents of any wire or oral communication, and no evidence derived therefrom, may be received at certain proceedings, including trials, "if the disclosure of that information would be in violation of this chapter." What disclosures are forbidden, and are subject to motions to suppress, is in turn governed by $\S 2518(10)(a)$, which provides for suppression of evidence on the following grounds ....

416 U.S. at 524; see also Chavez II, id. at 570-71. In fact, disclosure is governed not only by $\S \S 2515$ and $2518(10)(a)$, but also by the broader provisions of $\S 2517$. 
disclosures which violated the specific grounnds of section 2518(10)(a). ${ }^{133}$

In fact, whether the Congress intended to limit section 2515 in this fashion is uncertain. The legislative history is ambiguous. The Senate Judiciary Committee's report concerning Title III does describe section 2518(10)(a) as limiting the evidentiary sanction of section 2515 , but it appears that the real purpose of section 2518(10)(a) was to provide an explicit remedy "for the right created by section 2515 " while restricting that right to those persons who would have standing to object to unlawful interceptions under existing law. ${ }^{134}$

Furthermore, whether Congress intended to limit section 2515 's evidentiary sanction to just those situations described in section 2518(10)(a) assumes importance only because the Supreme Court majority interpreted the latter section in such a narrow fashion. If the Court's construction of section 2518(10)(a) had comprehended all violations of Title III's requirements and thus coincided with the scope of section 2515 , legislative intent would not be an issue. In other words, the key to the Supreme Court's Chavez decision was its construction in Giordano of section 2518(10)(a).

In Giordano, Justice White accepted some of the government's argument that because paragraphs (ii) and (iii) encompassed statutory violations, paragraph (i) must be restricted to violations of constitutional dimensions. ${ }^{135}$ However, he refused to accept the obvious implication of this analysis: that no purely statutory violation in obtaining a Title III order would make subsequent interceptions "unlawful" in terms of

${ }^{133}$ Cf. Gelbard v. United States, 408 U.S. 41, 47 (1972), in which the Court, assuming that the interception of the communications of grand jury witnesses had not been in conformity with Title III's "stringent conditions," concluded that $\$ 2515$ would forbid questioning the witnesses on the basis of those interceptions without inquiring whether the Title III violations fell within the specific grounds of $\$ 2518(10)(a)$.

${ }^{134}$ Senate Report No. 1097 identifies the purpose of $\S 2518(10)(a)$ as defining "the class entitled to make a motion to suppress," $S$. REP., supra note 3 , at 2185 , and establishing the "remedy for the right created by section 2515," id. 2195. Gelbard 7 . United States itself demonstrates that Title III forbids disclosures even in the situations to which a $\S 2518(10)$ (a) motion to suppress does not apply. In Gelbard the Court ruled that, although motions to suppress may not be made in the context of grand jury proceedings under $\$ 2518(10)(a)$, compelling an immunized witness to answer questions suggested by improperly intercepted communications was forbidden. 408 U.S. at $\mathfrak{\jmath} 1-52$.

${ }^{135}$ Giordano II, 416 U.S. at 525 . The government's construction of $\$ 2518(10)(a)(i)$ was in part confirmed by the omission from that section of a fourth ground for suppression-lack of probable cause-which had appeared in earlier drafts and was apparently omitted because it was regarded as unnecessary. Id. at 325-26. 
paragraph (i). Instead, he devised a distinction between statutory provisions which directly limited the use of electronic surveillance techniques and provisions which did not. ${ }^{136}$

Justice White's analysis is subject to criticism on a number of counts. In the first place, many interception orders or procedures which would violate the statutory provisions to which paragraphs (ii) and (iii) refer would also violate the Constitution. ${ }^{137}$ Consequently, the distinction between those paragraphs as referring only to statutory violations and paragraph (i) as referring only to constitutional violations is artificial.

Secondly, the assumption that Congress intended any of the three paragraphs to refer to constitutional restrictions or requirements is questionable. ${ }^{138}$ With the exception of probable cause standards, ${ }^{139}$ nothing in the Senate Report or in the statute itself suggests an intention to incorporate by reference whatever doctrinal variations the courts might adopt in construing the fourth amendment. Indeed, other sections of the 1968 Omnibus Crime Control and Safe Streets Act suggest quite the opposite intention. ${ }^{140}$ Congress did seek to conform its procedure to the requirements of Berger $v$. New York ${ }^{141}$ and

${ }^{136}$ Id. at $527-28$.

${ }^{137}$ For example, § 2516 permits law enforcement officers to engage in electronic interceptions pursuant to a court order granted in conformity to $\S 2518$. Such a court order would not satisfy $\S 2518(10)$ (a)(ii) if it failed to include the instructions and restrictions which that section requires: it would be insufficient on its face. In many instances it would also offend the fourth amendment. Compare 18 U.S.C. $\S 2518(4)$ (b) (order must specify the nature and location of facilities as to which, or the place where, authority to intercept is granted); $i d$. $\$ 2518(4)$ (e) (order must specify period of time during which such interception is authorized); and id. $\$ 2518(8)$ (a) (immediately upon expiration of order agents must make return of recording of intercepted communications to the issuing court), with Berger v. New York, 388 U.S. $41,58-60$ (1967). Furthermore, the failure of government agents to conduct an electronic surveillance in conformity to the statutorily mandated requirements of an interception order may also offend the Constitution. See, e.g., United States v. Eastman, 465 F.2d 1057, 1062-64 (3d Cir. 1973) (failure to notify subjects of electronic interceptions that surveillance occurred); United States v. Scott, 331 F. Supp. 233, 248 (D.D.C. 1971) (failure to minimize interceptions).

${ }^{138}$ Justice White made this assumption because he regarded the alternative as "most unlikely." Giordano II, 416 U.S. at 526.

${ }^{139} \mathrm{See} 18$ U.S.C. $\$ 2518(3)$ (1970); S. ReP., supra note 3, at 2191.

140 Title II of the Act included several provisions intended to change judge-made rules which the Supreme Court had enunciated either pursuant to its supervisory power over the federal courts or pursuant to its ultimate authority to interpret the Constitution. Those provisions, if valid, would overrule United States v. Wade, 388 U.S. 218 (1967), repeal the McNabb-Mallory rule, see McNabb v. United States, 318 U.S. 332 (1943); Mallory v. United States, 354 U.S. 449 (1957), and eliminate the mandatory warning requirements of Miranda v. Arizona, 384 U.S. 436 (1966). 18 U.S.C. $\$ \$ 3501,3502$ (1970). See text accompanying note 145 infra.

141388 U.S. 41 (1967). 
Katz $v$. United States ${ }^{142}$ by detailed legislative provisions. ${ }^{143}$ It reasonably could conclude that those provisions comprehended and, in some respects, exceeded the constitutional requirements. ${ }^{144}$ It might even believe that if those provisions relaxed judge-made standards, the statute would control. ${ }^{145}$

Thirdly, Justice White's construction of paragraph (i) was intended to save paragraphs (ii) and (iii) from the ignominy of surplusage, ${ }^{146}$ but the construction he adopted failed to do so. Unless one infers that the statutory prohibitions in paragraphs (ii) and (iii) were not intended to "play a central role in the statutory scheme," 147 such violations would also be comprehended within Justice White's interpretation of paragraph (i).

Finally, Justice White's construction is questionable because paragraph (i) is susceptible to other equally plausible interpretations. One possible interpretation of paragraph (i) of section 2518(10)(a) would construe the phrase "unlawfully intercepted" exactly as that concept is used in Title III's criminal provision, section 2511. Section 2511(1) prescribes criminal penalties for the willful interception of wire or oral communications except as specifically provided by the Title III procedure, and for the willful disclosure or use of the contents of such communications by any person having reason to know that the interception was criminal. ${ }^{148}$ Section $2511(2)$ then describes four situations in which the willful interception, disclosure, or

142389 U.S. 347 (1967).

${ }^{143}$ S. ReP., supra note 3, at $2113,2163$.

${ }^{14}$ Examples of provisions of Title III which go beyond the Constitution's requirements include the authorization requirement of $\S 2516(1)$; the provisions of $\S 2516$ which make electronic surveillance available only in cases of certain serious crimes; and the provision of $\S 2518(6)$ permitting issuing judges to require periodic reports during the duration of the order.

${ }^{145}$ See generally Burt, Miranda and Title II: A Morganatic Marriage, 1969 SuP. CT. Rev. 81, 118-23, 131-34; Note, Congressional Power Under Section Five of the Fourteenth Amendment, 25 Stan. L. Rev. 885, 898-902 (1973).

146 Giordano II, 416 U.S. at 526.

${ }^{147}$ Id. at 528.

${ }^{148}$ Section 2511(1) establishes criminal penalties for any person who commits any one of four categories of acts "[e]xcept as otherwise specifically provided in this chapter." The four proscribed categories are: (a) willfully intercepting or attempting to intercept any wire or oral communication, or procuring another to do so; (b) willfully using or attempting to use any electronic, mechanical, or other device to intercept oral communications under circumstances subject to congressional regulation, or procuring another to do so; (c) willfully disclosing or attempting to disclose to another the contents of any wire or oral communication, "knowing or having reason to know that the information was obtained through the interception of a wire or oral communication in violation of this subsection;" and (d) willfully using or attempting to use the contents of any wire or oral communication, "knowing or having reason to know 
use of communications which would otherwise offend section 2511(1) "shall not be unlawful."149

Under this approach, paragraph (i) of section 2518(10)(a) would mandate suppression whenever the disclosure or use of the challenged evidence would constitute a crime under section $2511(1) .{ }^{150}$ The moving party would have to demonstrate that the original interception was willfully made in conformity with the statute's requirements; the suppression of intercepted communications would be required if the government willfully violated even "technical" requirements relating to the Title III application, a result not inconsistent with section 2515 .

This construction of paragraph (i) would not require suppression of communications improperly intercepted in the belief that the interception was proper; the good faith of the interceptor would be a defense to the suppression motion. But

that the information was obtained through the interception of a wire or oral communication in violation of this subsection." 18 U.S.C. $\$$ 2511(1)(a), (b), (c), (d) (1970) (emphasis added). See note 150 infra.

149 The four situations are those in which a party to the communication has consented to its interception and the interception is accomplished either under color of law or privately, but for a lawful purpose; in which an officer, employee, or agent of a communications common carrier or a switchboard operator intercepts a wire communication in the normal course of employment or under other specified circumstances; or in which an officer, agent, or employee of the Federal Communications Commission intercepts a wire or radio communication in the performance of an official duty. 18 U.S.C. $\$ \S 2511$ (2)(a), (b), (c), (d) (1970).

${ }^{150}$ One should distinguish between the proposed construction of $\$ 2518(10)(a)(i)$ and the similar but erroneous construction given to the same paragraph by some lower courts and, apparently, by the Chavez dissenters. The proposed construction would permit suppression pursuant to $\S 2518(10)(a)(i)$ whenever the moving party demonstrated that the use or disclosure of the intercepted communication would violate the criminal proscriptions of subparagraphs (c) or (d) of $\S 2511(1)$. See note 148 supra. Thus, the proposed construction would require the moving party to demonstrate that the person proposing to use or disclose the intercepted communication knew or had reason to know that the interception of the communication (1) violated the provisions of Title III and (2) was willfully accomplished. See 18 U.S.C. $\$ 2511$ (I)(a) (1970). Otherwise, the party proposing to use or disclose the intercepted communication would not know or have reason to know that the interception of the communication occurred in violation of "this subsection."

By contrast, some lower courts assumed that the use or disclosure of an intercepted communication would be "unlawful" within the meaning of subparagraphs (c) or (d) of $\S 2511(1)$, and therefore subject to suppression pursuant to $\S 2518(10)(\mathrm{a})(\mathrm{i})$, if the party proposing to use or disclose the communication knew or had reason to know that it was intercepted in violation of the provisions "of this chapter." United States v. Eastman, 465 F.2d 1057, 1061-62 (3d Cir. 1972); United States v. Narducci, 341 F. Supp. 1107, 1117 (E.D. Pa. 1972). See Chavez II, 416 U.S. at 584-87 (opinion of Douglas, J.). Such a construction fails to recognize that the interception of the communication must have occurred willfully as well as in violation of Title III's requirements in order to offend the criminal proscription of $\$ 2511$ (I)(a). See also Giordano II, 416 U.S. at 529 n. 18. 
to the extent that the government submitted in good faith an application which included constitutional defects, the courts presumably could suppress the Title III evidence regardless of the absence of any specific statutory authority. ${ }^{151}$ Nor would good faith avoid the suppression sanction if the defect complained of violated paragraphs (ii) or (iii).

A passage from the Chavez dissent suggests another possible explanation of the three paragraphs of section 2518(10)(a). Justice Douglas criticized the majority's narrow interpretation of paragraph (i) as follows:

The choice seems to be between attributing to Congress a degree of excessive cautiousness which led to some redundancy in drafting the protective provisions of $\S 2518(10)(a)$, or foolishness which led Congress to enact statutory provisions for law enforcement officials to scurry about satisfying when it did not consider the provisions significant enough to enforce by suppression. In view of the express prohibition by $\S 2515$ of disclosure of information "in violation" of the chapter, I would opt for the conclusion that Congress was excessively cautious, and that "unlawfully intercepted" means what it says. ${ }^{152}$

This approach suggests that any interception which does not conform to any of Title III's requirements should be subject to suppression under section 2518(10)(a). Although this approach to paragraph (i) would make paragraphs (ii) and (iii) redundant, it has considerable appeal. It would define as "unlawful" any electronic interception, disclosure, or use of any intercepted communication, unless specific Title III provisions explicitly permitted, and would make suppression available to aggrieved persons in any case in which the disclosure or use of the intercepted communications would violate section 2515.

Defining the phrase in paragraph (i), "unlawfully intercepted," in terms of the section 2515 prohibition deviates from the more narrow concept of unlawfulness which Congress employed in section $2511(1) .{ }^{153}$ But there is reason to

${ }^{151}$ See Cook v. United States, 401 U.S. 996 (1971) (Douglas, J., dissenting) (whether wiretap evidence was properly seized depends not upon Title III or administrative practice, but upon the fourth amendment), denying cert. to 432 F.2d 1093 (7th Gir. 1970).

152416 U.S. at 586 (opinion of Douglas, J.).

${ }^{153}$ Compare $\$ 2515$, quoted in note 65 supra, with $\$ 2511(1)$, discussed in note 148 supra. 
believe that such a broader definition would not offend the canons of statutory construction. ${ }^{154}$ Furthermore, paragraphs (ii) and (iii) of section 2518(10)(a) are not limited by the element of willfulness included in the criminal provisions, ${ }^{155}$ indicating Congress' intention to make the suppression remedy available on a considerably broader scale.

Furthermore, Congress itself suggested in the Organized Crime Control Act of $1970^{156}$ that a violation of any Title III provision should fall within the section 2518(10)(a)(i) definition of an unlawful interception. One provision of that statute ${ }^{157}$ establishes a new procedure for suppressing the fruits of illegal electronic interceptions, and provides for limited disclosure of intercepted communications which the court finds to be the fruit of "an unlawful act." The statute defines "an unlawful act" to include any electronic interception made "in violation of the Constitution or laws of the United States or any regulation or standard promulgated pursuant thereto."158 This definition of unlawful acts subject to suppression appears to comprehend violations of any Title III provision, not just those specified in section $2518(10)(a) .{ }^{159}$

In contrast with these suggested alternatives, Justice White's interpretation of section 2518(10)(a) suffers from its failure to account for section $2515 .^{160}$ Justice White's inter-

${ }^{154}$ See Atlantic Cleaners \& Dyers, Inc. v. United States, 286 U.S. 427, 433 (1932).

${ }^{155}$ Not only do the criminal proscriptions of $\S 2511(1)$ specify willfulness as a necessary element, Giordano II, 416 U.S. at 529 n.18, but Congress also explicitly provided that good faith reliance upon an interception order would constitute a complete defense in any action seeking to impose Title III's civil or criminal penalties. 18 U.S.C. $\S 2520$ (1970).

15684 Stat. 922 (codified in various sections of 18 U.S.C.).

15718 U.S.C. $\$ 3504$ (1970).

${ }^{158} \mathrm{Id}$. $\$ 3504$ (b).

${ }^{159}$ A possible, if unlikely, reading interprets the three paragraphs of $\S 2518(10)(a)$ in an internally consistent manner by assuming that paragraph (i) refers to interceptions conducted without the authority of any interception order whatsoever, see United States v. Liddy, 354 F. Supp. 217, 219 n.1 (D.D.C. 1973). Congress clearly intended to prohibit such interceptions or the disclosure of their fruits by all available means. S. REP., supra note 3, at 2153-54, 2180-82. Of course, such an interpretation of paragraph (i) would make suppression inapplicable to situations in which the court issued a facially sufficient order on the basis of a defective application; but Congress might have assumed that the substantial responsibilities which other provisions of the statute imposed upon issuing judges would make reference to such situations unnecessary. Note that this proposed construction of $\S 2518(10)(a)$ also assumes that Congress intended to limit the evidentiary sanction of $\S 2515$ to only those situations described in $\$ 2518(10)(a)$; but see text accompanying notes 127-34 supra.

${ }^{160}$ See text accompanying notes $127-31$ supra. 
pretation may be supportable, but is by no means compelled by the words of section $2518(10)(a) .{ }^{161}$ And, as the Chavez dissent noted, Justice White's interpretation assumes a license "to pick and choose" among the various provisions of Title III and to withhold the suppression sanction unless the challenged interception procedure violates what the courts consider a "central" statutory provision. ${ }^{162}$ There is no legislative history to support the view that the courts were to exercise discretion on this basis; Justice White extrapolated it from the undeniable importance of the authorization requirement, ignoring the equally great importance Congress attached to the evidentiary sanction of section 2515 .

\section{INSTITUTIONALIZED DECEPTION}

By limiting Title III's suppression sanction to statutory violations which offend a "central safeguard" and by deciding that Title III's identification requirements serve no such purpose, the majority ignored an important aspect of the Justice Department's authorization procedure: aside from the possible culpability of any individual involved, the government's routine misrepresentations concerning the authorization process constituted an institutionalized practice of deception. From the time that the Justice Department began using the Title III procedure until the spring of 1972, when the Department substantially revised its authorizing process, government attorneys routinely misrepresented the facts of that authorizing process in over 525 Title III proceedings. ${ }^{163}$ There is no question that the government documents persuaded the issuing judges that authorization had occurred as described. ${ }^{\mathbf{1 6 4}}$ As several courts

161 This is the very criticism Justice Rehnquist leveled against the Gelbard majority's interpretation of Title III. Gelbard v. United States, 408 U.S. 41, 71 (1972) (Rehnquist, J., dissenting).

162416 U.S. at 586 (opinion of Douglas, J.).

${ }^{163}$ Giordano Brief, supra note 17, at 4; see text accompanying notes 15-21 supra.

To reiterate, the government made these misrepresentations in three ways. First, government attorneys seeking Title III orders would submit sworn applications which asserted that the Attorney General had specially designated Assistant Attorney General Will Wilson to act and that Wilson had authorized submission of the Title III application to the issuing judge. Second, the applying attorneys would also submit proposed orders to the issuing judges which included a finding that the application had been authorized as described. Third, the applying attorneys would include as exhibits to their sworn applications what purported to be personal letters to them from Will Wilson authorizing the attorneys to submit the applications.

${ }^{164}$ See Chavez I, 478 F.2d at 515; United States v. King, 478 F.2d 494, 500 (9th Cir.), cert. denied, 414 U.S. 846 (1973); United States v. Marder, 362 F. Supp. 484, 
noted, these documents created the "unmistakable impression" that Will Wilson had made the discretionary decision which section $2516(1)$ required. ${ }^{165}$ Nor is there any question that the government attorneys who actually submitted these documents to the issuing judges did so in good faith. ${ }^{166}$ The applying attorneys were as misled concerning their authority to proceed as were the issuing judges, and undoubtedly they were equally surprised when the Justice Department disclosed its new version of what had actually occurred.

However, the good faith of the individual attorneys who actually submitted the Title III documents does not excuse the misstatements involved. Nor is it sufficient to explain away those misstatements as a regrettable, but inevitable, result of "a perpetual bureaucratic tendency." ${ }^{167}$ As a matter of plain fact, the high-level officials who established the Justice Department's authorization procedure and approved the use of the form documents knew those documents were false. ${ }^{168}$ Those officials have admitted knowing the text of the Will Wilson letter, the Title III application, and the proposed court order; ${ }^{\mathbf{1 6 9}}$

486 (S.D. Fla. 1973), rev'd, 496 F.2d 1405 (5th Cir. 1974); United States v. Sklaroff, 362 F. Supp. 478, 480-81, 484 (S.D. Fla. 1973), rev'd, 500 F.2d 1183 (5th Cir. 1974). ${ }^{165}$ See United States v. Stanley, 360 F. Supp. 1112, 1114-16 (N.D. Ga. 1973), rev'd, 496 F.2d 1406 (5th Cir. 1974); United States v. Robinson, 359 F. Supp. 52, 55-56 (S.D. Fla. 1973), rev'd per curiam, 496 F.2d 225 (5th Cir. 1974) (en banc).

${ }^{166}$ See United States v. King, 478 F.2d 494, 505 (9th Cir.), cert. denied, 414 U.S. 846 (1973); United States v. Robinson, 359 F. Supp. 52, 56 (S.D. Fla. 1973), rev'd per curiam, 496 F.2d 225 (5th Cir. 1974) (en banc).

167 United States v. Bowdach, 366 F. Supp. 1368, 1373 (S.D. Fla. 1973).

${ }^{168}$ At the Marder evidentiary hearing, see note 14 supra, former Attorney General John N. Mitchell testified that the Department processed requests for authorization according to a standard procedure. Marder Record, supra note 14, at 43; see Giordano Brief, supra note 17, at 4-9. Several of the other Justice Department officials testified that they had played some role in establishing that standard procedure and were to some degree responsible for the procedures actually employed. Marder Record, supra note 14, at 151 (Petersen), 224 (Lindenbaum), 264 (Wilson). As to the knowledge of these officials, see notes 169-71 infra \& accompanying text. Only Will Wilson himself testified that he was unfamiliar with the representations made in the Title III applications concerning his role and that he did not know that applying attorneys were submitting the "Will Wilson" letters to the issuing judges. Marder Record, supra note 14, at 261, 268, 271. "I did not know exactly what use was made of them," he said. Id. 261.

${ }^{169}$ At the Marder hearing, Mitchell testified that the government file on each Title III application would contain the application, supporting affidavit, proposed court order, the "Will Wilson" letter, and the form memorandum from the Attorney General to Wilson as well as various memoranda summarizing the facts of the particular application and recommending that the application be authorized. Marder Record, supra note 14, at 38-39, 61-63, 83-85. He testified that in each case he would read parts, if not all of these documents, id. 63,119 . He explicitly admitted knowing the 
they knew what representations those documents made concerning the authorization process. ${ }^{170}$ At least some of them knew that the applying attorneys would submit the false Will Wilson letters to the issuing judges in order to corroborate their asserted authority to act. ${ }^{171}$ Although these high officials did not personally mislead the issuing judges, they knowingly participated in a process which caused others to do so. To the extent that the government is treated as an entity, ${ }^{172}$ therefore, it is responsible for communicating to the courts statements of facts known to be untrue. ${ }^{173}$

contents of the "Will Wilson" letter, but stated he did not know if Wilson, in fact, reviewed the files, $i d$. 80-82; nor did he know that Wilson was not signing the "Will Wilson" letters, $i d .82$.

Henry Petersen testified that he normally reviewed Title III files on behalf of the Criminal Division before the Attorney General would see them, id. 140-41. He knew that the proposed court orders and the "Will Wilson" letter suggested that Wilson was the authorizing official, id. $168,178$.

Sol Lindenbaum also testified that he would review Title III files before the Attorney General would see them, id. 208. See also note 43 supra. He also admitted some responsibility for the specific language employed in the form memorandum addressed to Will Wilson. Marder Record, supra note 14, at 224.

Will Wilson admitted some familiarity with the contents of the "Will Wilson" letters and, in fact, testified that in 1969, he even signed a few, id. 259-60, 271. Furthermore, he apparently played some role in the review process in some individual cases, id. 83, 103, 170. However, he disclaimed knowledge of the purposes for which the "Will Wilson" letters were used; see note 168 supra.

Harold Shapiro testified that he normally handled Title III applications only when Petersen was unavailable, Marder Record, supra note 14, at 227. See also note 41 supra.

Various witnesses also testified that, until the government's disclosures, no one outside of the office of the Attorney General knew that anyone besides Mitchell himself was initialling the form memoranda or purporting to approve Title III applications. Marder Record, supra note 14, at 155-56, 261.

${ }^{170}$ Mitchell, Petersen, and Wilson specifically testified to such knowledge. Marder Record, supra note 14, at 100-01, 168, 259-60.

${ }^{171}$ Id. 82 (Mitchell), 168 (Petersen), 222 (Lindenbaum). But see note 168 supra (Wilson).

${ }^{172}$ The Supreme Court has ruled that "the prosecutor's office is an entity" and that the government is bound by the knowledge or promises of any of its representatives, even if unknown to his associates or superiors, Giglio v. United States, 405 U.S. 150, 154 (1972); Santobello v. New York, 404 U.S. 257, 262, 263 (1971). The Court also has suggested that prosecutors are ethically responsible for the conduct of police officials in connection with pending cases. United States v. Ash, 413 U.S. 300, 320 (1973).

${ }^{173}$ The government also contended before the Supreme Court that its Title III documents involved no misrepresentations because the reports which it submitted annually to the Administrative Office of the United States Courts indicated that the Attorney General had "personally approved each of the reported applications and. as authorized by provisions of Title 18 U.S.C. Section 2516. specially designated an Assistant Attorney General to authorize its filing." Giordano Brief, supra note 17. at 8; see note 116 supra \& accompanying text. However. such disclosures certainly were not made known to the issuing judges. particularly at the time they reviewed the Title 
Ironically, most courts, including the Supreme Court, have been more than willing to overlook the implications of this conduct, ${ }^{174}$ avoiding the issue by asserting that the deception served no purpose because the orders could have been obtained by following orthodox procedures. ${ }^{175}$ If the government had actually identified the Attorney General as the authorizing officer in its Title III applications, it undoubtedly would have enjoyed the same high success rate in securing interception orders from the federal courts. ${ }^{\mathbf{1 7 6}}$

Why, then, did the Justice Department engage in this deception? There is no firm answer, but one explanation does exist. The Justice Department may have used its misleading Title III documents to foster the appearance of scrupulous compliance with section 2516(1) while actually employing a procedure which it regarded as more bureaucratically desirable than that which the statute required. ${ }^{\mathbf{1 7 7}}$

The government's disclosures concerning the authorization process indicate its actual reviewing procedures conformed to a bureaucratic model. ${ }^{178}$ Each Title III application under-

III applications. Commonly, the Administrative Office publishes its summaries of Title III activity in April of the year following the calendar year during which the activity occurred, see ADMIN. OfFICE OF THE U.S. CourTs, supra note 13. Furthermore, as Justice Douglas pointed out, the government's annual reports for the calendar years following 1969 "did not acknowledge that Mitchell had personally authorized the surveillance attributed to his subordinates." Chavez II, 416 U.S. at 595-96 (opinion of Douglas, J.).

${ }^{174}$ See, e.g., United States v. James, 494 F.2d 1007 (D.C. Cir. 1974).

${ }^{175}$ See text accompanying notes 91-98 \& 110-1 I supra. It may have been important who in fact authorized the Title III applications. District court judges are experienced at determining probable cause for a search warrant, but may have encountered greater difficulty in Title III cases when assessing the need for electronic surveillance or the reasonable duration of a proposed intrusion. In such cases, a judge might well defer to the judgment of the authorizing officer identified in the application. Had the judges known the true facts concerning the authorization process, they may well have been unwilling to rely upon the representations of the government's applications and in the "Will Wilson" letters.

${ }^{176}$ The annual reports of the Administrative Office of the United States Courts indicate that there were 525 Title III applications submitted to federal judges between 1969 and 1972 which misidentified the authorizing officer, only one of which was refused. See note 13 supra.

${ }^{177}$ See Giordano I, 469 F.2d at 528.

${ }^{178}$ German sociologist Max Weber described the principle characteristics of the classic bureaucratic model in terms of four specific functions:

(1) bureaucratic jurisdiction is precisely fixed by operating rules and regulations, (2) bureaucratic structures are hierarchically organized on the basis of a firmly established pattern of superior-subordinate relationships, (3) the formal internal operation, or management, of the bureaucracy is accomplished through the transmission of intraorganizational communications, decisions, directives, and so on, in the form of written documents, which 
went close scrutiny by specially trained, lower level officials and then received successive reviews by supervisory officials at increasingly higher levels of the Department. ${ }^{179}$ When an application reached the very highest levels, the reviewing officials would know that careful examinations already had occurred and that a series of subordinate officials had already recommended approval. ${ }^{180}$

However, the Justice Department also knew that Congress specifically adopted Title III's authorization requirement to make certain that the judgment to seek a court order was not an "institutional decision" effectively made by the lower echelons of the Department. ${ }^{181}$ Therefore, it chose to describe the authorization procedure in its Title III applications-and other documents in a manner which would satisfy that Congressional concern while concealing the bureaucratic process actually at work.

are preserved as permanent records of the organization, and (4) bureaucratic officials must reflect a high degree of administrative specialization and expertise, not only concerning their specific functional responsibilities, but also concerning the operating rules, regulations, and procedures of the bureaucratic organization itself.

L. Gawthrop, Bureaucratic Behavior in the Executive Branch 2 (1969). See also P. Blau \& M. Meyer, Bureaucracy in Modern Society 18-23 (2d ed. 1971); R. Presthus, The Organizational Society: An Analysis and a Theory 5 (1962). Furthermore, the theoretical decisionmaking structure of the bureaucratic organization contemplates a corps of top-level officials-the policy makers-who establish sometimes detailed and explicit criteria for action which lower-level officials then apply to individual cases. L. GAwTHRop, supra at 15-16. In fact, however, this theoretical conception of bureaucratic function does not describe reality. For various reasons relating to the inability of "policy makers" to police the actual implementation of their directives and to the dependency of the "policy makers" upon their subordinates to collect, summarize, and communicate the relevant data necessary for policy determinations, the organization's policies are largely created by its lower echelons. The top level "official policy makers, in many respects, become policy ratifiers who grant organizational legitimacy to certain suggested courses of action," Id. 16-18, 111-18. See also P. Blau \& M. MeYer, supra at 93; P. Blau, The Dynamics OF BUREAUCRACY 123-28 (2d ed. 1963).

${ }^{179}$ Giordano Brief, supra note 17, at 4-6. See also notes 41 \& 85 supra. The government argued that this procedure satisfied the intention of Congress that the Attorney General or a specially designated Assistant Attorney General "establish basic guidelines and ... retain the ultimate responsibility for their compliance, permitting their subordinates to act under their direction and pursuant to their policies in particular cases." Giordano Brief, supra note 17, at 55; see note 178 supra.

${ }^{180}$ At the Marder hearing, Henry Petersen testified that the "records copy" of each Title III file would indicate by initials the identity of each individual in the chain of command who had reviewed the file and had recommended authorizing the application. Marder Record, supra note 14, at 171-72. See also id. 278-79.

181 United States v. Cox, 462 F.2d 1293, 1300 (8th Cir. 1972), cert. denied, 416 U.S. 918 (1974). The Justice Department disclaimed such an understanding of Congress' intent in its Giordano brief, although section 1.2 of the Department's Title III Manual 
An examination of the text of the Will Wilson letter supports this explanation. The draftsman of that form letter took great care to track the pertinent provisions of Title III. ${ }^{182}$ Indeed, the letter goes beyond the statutory requirements by asserting that its purported author had carefully reviewed the file and the relevant circumstances and personally had made determinations of necessity and probable cause. ${ }^{183}$ Title III requires no such findings as part of the authorization process, but the form letter asserts them. The standardized language of the Title III applications and proposed court orders concerning the authorizing process exhibit the same care in tracking the statute's provisions. The "unmistakable impressions" which these documents created concerning the authorization process were carefully conceived and intentionally induced. ${ }^{184}$

If the Court had recognized the intentional nature of the government's misstatements, it might well have ordered suppression by analogy to the rules which some courts employ

flatly states that the purpose of $\$ 2516$ "is to insure strict, centralized control of the administration of Title III." Compare Giordano Brief, supra note 17, at 55, with U.S. DEP'T OF JUSTICE, supra note 15 , at 7.

That Congress did intend the "authorizing officer" to make a specific decision in each individual case is too evident to be ignored. The language of $\S 2516(1)$ clearly contemplates that the authorizing officer will act with respect to each individual application, and witnesses testifying in favor of a wiretap statute before Senator McClellan's subcommittee emphasized the importance of such an individual screening as one of the proposed statute's important protections. Hearings, supra note 8, at 171-72 (Chief Judge Lumbard of the United States Court of Appeals for the Second Circuit), 1095, 1117 (New York County District Attorney Frank Hogan). See also Giordano II, 416 U.S. at 514-22. Furthermore, ensuring such personal attention in each case was precisely the reason that in 1961 the Justice Department itself recommended that Congress include a provision similar to $\S 2516(1)$ in a proposed wiretap statute. See text accompanying note 11 supra. It is difficult, if not impossible, not to conclude that "Congress wanted to make certain that every such matter would have the personal attention of an individual appointed by the President and confirmed by the Senate." United States v. Robinson, 468 F.2d 189, 192 (5th Cir. 1972), remanded, 472 F.2d 973 (Jth Cir. 1973) (en banc). Cf. A.B.A. Standards Relating to Electronic SurveilLANCE, supra note 4, at 132.

${ }^{182}$ See United States v. King, 478 F.2d 494, 499-500, 504 (9th Cir.), cert. denied, 414 U.S. 846 (1973); United States v. Robinson, 359 F. Supp. 52, 55 (S.D. Fla. 1973), rev'd per curiam, 496 F.2d 225 (5th Cir. 1974) (en banc). Cf. Giordano Brief, supra note 17, at 7 (form memorandum to Will Wilson "tracked the language of Section 2516(1).").

${ }^{183}$ Note 17 supra.

${ }^{184}$ See United States v. King, 478 F.2d 494, 504 (9th Cir.), cert. denied, 414 U.S. 846 (1973).

At the Marder hearing, various witnesses attempted to explain why the Justice Department had included in its various Title III documents statements which clearly appeared to describe an authorization procedure substantially different from that which those officials testified had actually occurred. They uniformly asserted that 
when defendants challenge the factual assertions in facially sufficient search warrant affidavits on the ground that they contain inaccurate facts or misrepresentations. ${ }^{185}$ The state and lower federal courts presently disagree whether they should ever consider such challenges and, if so, under which circumstances they should grant relief. ${ }^{186}$ Some courts follow the traditional rule that, absent a specific statute, such challenges

the first person representations of the "Will Wilson" letter were simply intended to reflect "institutional determinations" by the Criminal Division of the Department. Marder Record, supra note 14, at 151-52, 260, 270. Cf. text accompanying note 181 supra. Wilson testified that the "Will Wilson" letter was of no operational significance, but simply informed the applying attorney that his application had been approved. Id. 267; see text accompanying notes 48-57 supra.

The witnesses encountered greater difficulty in reconciling their assertions that the Attorney General had actually authorized Title III applications with the statements in all the Title III documents that he had simply specially designated Wilson to make that discretionary decision. The explanation they gave was that the "special designation" to which the various Title III documents referred was not a "special designation" within the meaning of $\$ 2516(1)$, but simply the delegation of the performance of a ministerial act. Id. 116, 178-79. See United States v. Roberts, 477 F.2d 57, 59 (7th Cir. 1973), cert. denied, 417 U.S. 908 (1974). For this reason the government strongly resisted defense counsel efforts to characterize the form memorandum from the Attorney General to Will Wilson as "a designation memo"; it contended the memorandum was, in fact, the authorizing document. Marder Record, supra note 14 , at $36,101,157-58,238-40$. However, this contention was severely undercut by an internal department document which itself referred to the "Will Wilson" letter as "a proposed letter of authorization" and to the form memorandum as "a proposed designation memorandum." Id. 158, 240.

${ }^{185}$ Some defendants argued a different analogy, to the requirements of former rule 41 of the Federal Rules of Criminal Procedure. Until 1972 that rule required search warrants to identify the affiants whose statements prompted the magistrate's finding of probable cause. (In 1972 the rule was amended to eliminate this requirement as "unnecessary paperwork. . . . A person who wishes to challenge the validity of a search warrant has access to the affidavits upon which the warrant was issued." FED. R. CRIM. P. 41, Advisory Comm. Note, 56 F.R.D. 169 (1972)). Occasionally, defendants would demonstrate that search warrants misidentified the affiants, and most courts would suppress the fruits of the search in such cases. See, e.g., King v. United States, 282 F.2d 398 (4th Cir. 1960); United States v. Carignan, 286 F. Supp. 284 (D. Mass. 1967). But see United States v. Averell, 296 F. Supp. 1004 (E.D.N.Y. 1969). At least two lower courts found this analogy persuasive when considering the misidentification of the authorizing officer under Title III, United States v. Stanley, 360 F. Supp. 1112, 1118-19 (N.D. Ga. 1973); Focarile, 340 F. Supp. at 1057, but the Supreme Court rejected it in an almost offhand manner, distinguishing the search warrant affiant cases in a footnote on the grounds that the affiant's identity related to probable cause while in Title III cases the authorizing officer's identity was immaterial to that determination, Chavez II, 416 U.S. at 574 n.5.

${ }^{186}$ See Kipperman, Inaccurate Search Warrant Affidavits as a Ground for Suppressing Evidence, 84 HaRv. L. Rev. 825 (1971); Mascolo, Impeaching the Credibility of Affidavits for Search Warrants: Piercing the Presumption of Validity, 44 Cons. B.J. 9, 18-20 (1970); Note, Search Warrant Affidavits: The Constitutional Constraints, 23 DRAKE L. REv. 623, 635-36 (1974); Comment, The Outuardly Sufficient Search Warrant Affidavit: What If It's False?, 19 U.C.L.A.L. Rev. 96 (1971); Annot., 5 A.L.R.2d 394 (1949). 
are improper. ${ }^{187}$ They regard the issuing magistrate's determination of the credibility of the affiant and the accuracy of the affidavit as conclusive; only the inference drawn from the facts stated in the affidavit - the magistrate's finding of probable cause -is subject to review. Other courts do allow hearings in some circumstances permitting defendants to dispute the factual assertions on the basis of which the magistrate made a finding of probable cause, but disagree among themselves whether good faith misstatements of material fact, as opposed to outright perjury, justify suppression. ${ }^{188}$

Those courts which observe the traditional rule precluding consideration of challenges assert that the fourth amendment does not require an inquiry into the truth of the affidavit, ${ }^{189}$ and that such inquiries would undermine the solemnity of the warrant-issuing procedure ${ }^{190}$ and encourage extensive litigation, often on frivolous grounds. ${ }^{191}$ Such courts also may be concerned that allowing defendants to attack the factual accuracy of search warrant affidavits may lead in some instances

${ }^{187}$ See, e.g., People v. Bak, 45 Ill. 2d 140, 144, 258 N.E.2d 341, 343, cert. denied, 400 U.S. 882 (1970); State v. Anselmo, 260 La. 306, 314, 256 So. 2d 98, 103-04 (1971), cert. denied, 407 U.S. 911 (1972); State v. Petillo, 61 N.J. 165, 174-75, 293 A.2d 649, 653-54 (1972), cert. denied, 410 U.S. 945 (1973).

${ }^{188}$ See Note, supra note 186, at 636-37. Compare United States v. Marihar, 492 F.2d 897, 899-900 (8th Cir. 1974), and United States v. Carmichael, 489 F.2d 983, 988 (7th Cir. 1973) (en banc), with United States v. Thomas, 489 F.2d 664, 669 (5th Cir. 1973). Much of this confusion exists because the Supreme Court has consistently declined to decide the relevant issues, see Mitchell v. Illinois, 400 U.S. 882 , denying cert. to 45 Ill. 2d 148, 258 N.E.2d 345 (1970); Tucker v. Maryland, 386 U.S. 1024 (1967), denying cert. to 244 Md. 488, 224 A.2d 111 (1966); Rugendorf v. United States, 376 U.S. 528, 531-32 (1964); cases cited in note 187 supra, a reluctance which may find some explanation in the difficulty that lower courts and commentators have encountered in deducing the correct position from present fourth amendment doctrine, see Mascolo, supra note 186 , at 10 . The commentators generally agree that courts should permit defendants to attack the factual assertions in search and arrest warrant affidavits, Forkosh, The Constitutional Right to Challenge the Content of Affidavits in Warrants Issued Under the Fourth Amendment, 34 Онго Sт. L.J. 297, 336-40 (1973); Kipperman, supra note 186, at 830-33; Mascolo, supra note 186, at 25-30; Note, supra note 186, at 638-39; Comment, supra note 186, at 146-47, but they do not agree among themselves concerning what circumstances should justify relief. Compare Mascolo, supra note 186, at 30-31, and Comment, supra note 186, at 139-46, with Kipperman, supra note 186, at 830-33.

${ }^{189}$ Note, supra note 186, at 636; see United States v. Brunett, 53 F.2d 219, 225 (W.D. Mo. 1931); State v. Petillo, 61 N.J. 165, 174-75, 293 A.2d 649, 653-54 (1972), cert. denied, 410 U.S. 945 (1973).

${ }_{190}$ Note, Testing the Factual Basis for a Search Warrant, 67 Colum. L. REv. 1529, 1530 (1967).

${ }^{191}$ See State v. Petillo, 61 N.J. 165, 177-78, 293 A.2d 649, 655 (1972), cert. denied, 410 U.S. 945 (1973). See also Forkosh, supra note 188, at 339-40; Note, supra note 186, at 636 . 
to unjustifiable disclosures of the identity of confidential informants. ${ }^{192}$

Those who believe that misstatements of fact in search warrant affidavits should in some cases be subject to review emphasize the importance of the magistrate's warrant-issuing function. ${ }^{193}$ To the extent that the fourth amendment requires a neutral and detached magistrate to make the critical finding of probable cause, ${ }^{194}$ they argue, misstatements of fact which mislead the magistrate and prevent the proper performance of this function should not be allowed.195 Some courts restrict this reasoning to intentional misrepresentations, rejecting the suggestion that reasonable mistakes of fact, made by the affiant in good faith, should lead to suppression. They limit the suppression sanction by the professed objectives of the exclusionary rule. ${ }^{196}$

192 See Note, supra note 190, at 1532-34; Comment, supra note 186, at 123-33. 107-11.

${ }^{193}$ See, e.g., Forkosh, supra note 188, at 305-14; Comment, supra note 186, at

In repeated decisions, the Supreme Court has emphasized the importance of the magistrate's role. United States v. United States District Court, 407 U.S. 297, 316-18 (1972); United States v. Ventresca, 380 U.S. 102, 109 (1965); Johnson v. United States, 333 U.S. 10, 14 (1948). Because the fourth amendment requires the magistrate to make a meaningful determination of probable cause, the Court has insisted that search warrant affidavits include explicit statements of specific facts, Aguilar v. Texas, 378 U.S. 108, 114 (1964), and has condemned affidavits which only assert the affiant's own conclusions, Giordenello v. United States, 357 U.S. 480, 485-86 (1958), for "subjective good faith" is insufficient to satisfy the Constitution, Beck v. Ohio, 379 U.S. 89, 97 (1964),

The commentators also emphasize that defendants should be permitted to attack the accuracy of search warrant affidavits in order to advance the search for truth, Mascolo, supra note 186 , at $25-28$, and because the reasons for the contrary rule are simply insufficient; Kipperman, supra note 186 , at 830 . They would avoid the danger of excessive litigation with which the traditional rule is so concerned by requiring defendants to make a factual showing of positive misstatements before receiving a hearing on the claim. See United States v. Rael, 467 F.2d 333, 336 (10th Cir. 1972), cert. denied, 410 U.S. 956 (1973); United States v. Dunnings, 425 F.2d 836, 840 (2d Cir. 1969), cert. denied, 397 U.S. 1002 (1970); United States v. Askins, 351 F. Supp. 408, 413 (D. Md. 1972). See also Mascolo, supra note 186, at 28-30.

${ }^{194}$ Coolidge v. New Hampshire, 403 U.S. 443, 449-53 (1971).

195 United States v. Morris, 477 F.2d 657, 662 (5th Cir.), cert. denied, 414 U.S. 852 (1973). See United States v. Roth, 391 F.2d 507, 509 (7th Cir. 1967); United States v. Henderson, 17 F.R.D. 1, 2 (D.D.C. 1954).

${ }^{196}$ See United States v. Marihart, 492 F.2d 897 (8th Cir. 1974); United States v. Carmichael, 489 F.2d 983 (7th Cir. 1973) (en banc); Note, supra note 186, at 637-38.

Those courts which suggest that even innocent misstatements of material fact should justify suppression, United States v. Thomas, 489 F.2d 664 (5th Cir. 1973), probably go too far, see 3 C. Wright, Federal Practice and Procedure $\S 673$, at 107 (1969); Kipperman, supra note 186, at 832-33. The Supreme Court itself has acknowledged that courts should allow for reasonable mistakes by police officers in warrantless arrest situations, Brinegar v. United States, 338 U.S. 160, 176 (1949); see Mascolo, 
Most important for the analogy to Title III, the four federal appellate courts which have recently considered the issue agree that suppression would be proper in the case of a deliberate misstatement even if the misstated fact were not essential to the magistrate's finding of probable cause. ${ }^{197}$ That the remaining facts stated in the affidavit would themselves justify issuance of the warrant does not matter in such cases, for the failure to establish probable cause is not the basis for suppression; the sanction applies in order to vindicate the integrity of the courts and to deprive the government of the fruits of its misconduct. ${ }^{198}$ These same considerations apply equally to the Justice Department's intentional misrepresentations of its authorizing procedures in Title III cases.

It is true, of course, that the affiants in the Title III cases -the applying attorneys-did not intentionally or recklessly misstate the facts concerning their authorization. ${ }^{199}$ But the government is institutionally responsible for acts or knowledge to which not all its representatives are party. ${ }^{200}$ Viewed in this light, the government's misrepresentations take on far more serious overtones than the Supreme Court acknowledged. If intentional or reckless misstatements by individual affiants in ordinary search warrant cases require the suppression sanction despite their immateriality to the finding of probable cause, surely the courts should require no less when, as an institution, the government misleads issuing judges concerning statutorily mandated findings of fact. However, neither the Chavez majority nor the dissenters considered the purposeful character of the government's conduct; they simply considered whether Title III's identification requirements were central or peripheral to the statute's safeguards. In so doing, they ignored the most fundamental aspect of the government's authorization procedure.

supra note 186, at 12. It would be anomolous, therefore, to test search warrant affidavits by a higher standard, especially in view of the Court's announced preference for the warrant procedure. See Jones v. United States, 362 U.S. 257 (1960). See also note 193 supra.

197 United States v. Belculfine, I6 Crim. L. ReP. 2298 (1st Cir., Dec. 6, 1974); United States v. Marihart, 492 F.2d 897, 899-900 (8th Cir. 1974); United States v. Carmichael, 489 F.2d .983, 988-89 (7th Cir. 1973) (en banc); United States v. Thomas, 489 F.2d 664, 668-71 (5th Cir. 1973):

${ }^{198}$ See note 197 supra.

${ }^{199}$ See text accompanying note 166 supra.

${ }^{200}$ See note 172 supra. 


\section{Misreliance on $E_{X}$ Post $F_{\text {acto }}$ Government Affidavits}

The Supreme Court failed to consider another cluster of issues which turn on the propriety of the government's use of ex post facto affidavits and other salvaging evidence after the disclosure of Will Wilson's nonparticipation. These issues are important not only because they raise further questions about the Supreme Court's decision in Chavez, but also because they illustrate the dangers of overreliance by both the Supreme Court and many lower federal courts upon the representations of the government when acting as an advocate.

When the government sought to submit its affidavits to the district court in Chavez, the defendants objected, contending that such affidavits were improper, and requested an evidentiary hearing at which they could cross-examine the authors of the affidavits. The defendants even contended that, because of the extraordinary discrepancies between the government's Title III documents and its subsequent affidavits, the district court should discredit the latter. ${ }^{201}$

Both the district court and the court of appeals rejected these contentions. They preferred to assume that by personally initialing the memorandum addressed to Will Wilson, the Attorney General had personally approved the authorization request. Of course, their willingness to make this assumption may be explained, at least in part, by its immateriality to their ultimate decisions that the misidentification of the authorizing officer itself required suppression of the intercepted communications.

When the government petitioned the Supreme Court to review the Chavez decision, the defendants again contended that the record below was deficient and that certiorari therefore should be denied. ${ }^{202}$ The Supreme Court rejected this suggestion, and ultimately decided Chavez by assuming that the Attorney General had personally authorized the Title III application. ${ }^{203}$

\footnotetext{
${ }^{201}$ See note 89 supra.
}

202 Id.

${ }^{203} \mathrm{~A}$ careful reading of Justice White's Chavez opinion clearly indicates that he assumed the issues relating to the Attorney General's initialling of the form memorandum out of existence. See United States v. Brick, 502 F.2d 219, 226-27 (8th Cir. 1974) (Bright, J., concurring). Although he recognized that both lower courts had assumed "that the Attorney General had personally approved the request for authority to apply for the interception order, as his affidavit stated." 416 U.S. at 568. Justice 
By making this assumption, despite its recognition that discrepancies existed between the assertions contained in the Title III documents submitted to the issuing judge and the government's subsequent representations, ${ }^{204}$ the Court overlooked two issues-one evidentiary and one a combination of law and fact-which some lower courts have resolved in conflicting fashion. These issues relate to the critical determination whether the Attorney General's act of initialling the form memorandum addressed to Will Wilson satisfied the requirements of section 2516(1). Resolved against the government, they would have required the suppression of Title III interceptions even in cases in which the Attorney General personally participated in the authorization process.

\section{A. The Evidentiary Issue: Are the Government's After- the-Fact Affidavits Admissible Evidence of What Actually Occurred?}

The government confronted a difficult problem when it first disclosed that, contrary to its prior representation, Will

White described the issue in Chavez as whether misidentification of the authorizing officer requires suppression "when the Attorney General has in fact authorized the application to be made," $i d$. at 565 (emphasis added). In stating the court's holding on that issue, he explicitly elevated the assumption of the lower courts into a finding of fact:

When it is clearly established, therefore, that authorization of submission of a wiretap or electronic surveillance application has been given by the Attorney General himself, but the application, and, as a result, the interception order, incorrectly state that approval has instead been given by a specially designated Assistant Attorney General, the misidentification, by itself, will not render interceptions conducted under the order "unlawful" within the meaning of $\S 2518(10)(a)(i)$ or the disclosure of the contents of the intercepted communications, or derivative evidence, otherwise "in violation of" Title III within the meaning of $\$ 2515$.

Id. at 579. Consequently, the Court remanded Chavez to lower courts for further proceedings on other undecided issues in the case, not including any further consideration of the Attorney General's actions. Id. at 569-70 n.3.

By contrast, Justice Douglas' dissent qualified the assumption that the Attorney General had authorized the application by attributing its assertion to the Solicitor General, id. at 582 (opinion of Douglas, J.). Justice Douglas also quoted the various Title III documents in footnotes to his opinion, emphasizing the discrepancy between their representations and the Solicitor General's assertions by the use of italics. See id. at 582-84 nn.I-5. However, Justice Douglas stated in his opinion that on the strength of the government's affidavits, both lower courts "held that Mitchell did in fact authorize the application to be made." In this respect, the dissenters clearly misconstrued the action of the lower courts. See 478 F.2d at 515.

${ }^{204}$ Justice White explicitly referred to a "discrepancy between who had actually authorized the respective applications to be made, and the information transmitted to the District Court clearly indicating that Assistant Attorney General Wilson was the authorizing official." 416 U.S. at 566. 
Wilson had not authorized the submission of Title III applications. The standardized Title III documents used in each case had unequivocally asserted that the Attorney General had specially designated Will Wilson, and that Wilson had personally authorized each application. In order to preserve these Title III court orders in the light of Wilson's nonparticipation, the government was obligated to persuade the reviewing courts that those representations were incorrect, and that the Attorney General himself had performed the discretionary act which section 2516(1) requires. The government was largely successful in accomplishing this difficult task, partly because many reviewing courts were sympathetic to its effort $\mathrm{t}^{205}$ and partly due to the ingenuity with which it made its presentations.

The government made its telling disclosures concerning Will Wilson's non-role and the Attorney General's participation in a series of carefully orchestrated affidavits, which asserted that the Attorney General had "approved" the authorization request. ${ }^{206}$ The most significant portions of these affidavits were their conclusory assertions of the legal significance of the various Title III documents. For example, the standardized affidavits filed by Will Wilson's two deputies generally asserted that signing the "Will Wilson" letter was simply a "ministerial act" and that the letter merely notified the applying attorney that the Attorney General had acted favorably on his application. ${ }^{207}$ Similarly, many of John Mitchell's own affidavits described the form memorandum and the "Will Wilson" letter as simply "part of the procedure developed for transmittal of my approval to the applicant." 208 More importantly, the Mitchell affidavits also stated in firm and confident tones that his act of initialling the form memorandum "constituted a notification to the Assistant Attorney General of the Criminal Division that

${ }^{205}$ See text accompanying notes 286-87 infra.

${ }^{206}$ See, e.g., United States v. King, 478 F.2d 494, 500-02 (9th Cir.), cert. denied, 414 U.S. 846 (1973) (affidavits of John N. Mitchell, Harold P. Shapiro, and Sol Lindenbaum); United States v. Robinson, 472 F.2d 973, 978-82 (5th Cir. 1973) (en banc) (affidavits of Sol Lindenbaum, Henry E. Petersen, and Will Wilson); notes 41 , 43, 85-87 supra.

${ }^{207}$ See notes 41, 85, 206 supra. See also United States v. Cox, 462 F.2d 1293, 1298 n.5 (8th Cir. 1972), cert. denied, 417 U.S. 918 (1974); United States v. Doolittle, 341 F. Supp. 163, 165-66 (M.D. Ga. 1972).

${ }^{208}$ See United States v. King, 478 F.2d 494, 500-01 (9th Cir.), cert. denied, 414 U.S. 846 (1973); United States v. Ceraso, 467 F.2d 647, 650-51 n.7 (3d Cir. 1972); United States v. Doolittle, 341 F. Supp. 163, 170-71 (M.D. Ga. 1972). 
the discretionary action of approving the request . . had been taken by me." 209

Despite what one court described as the "striking" contrast between these affidavits and the Title III documents submitted to the issuing judges, ${ }^{210}$ most courts accepted the affidavits at face value. They adopted the assertions in the affidavits concerning what the Attorney General had legally accomplished by initialling the form memorandum without even considering the meaning of the memorandum's text. ${ }^{211}$ Indeed, some courts even described the memorandum as effecting a special designation, but concluded that the Attorney General's initials authorized the application. ${ }^{212}$ Other courts refused to construe the meaning of the memorandum because, in the light of the government's affidavits, finding that the memorandum accomplished only a special designation would "elevate semantics above reality." "213 Finally, some courts accepted the government's assertions that the memorandum was ambiguous and relied upon the government's affidavits to "clarify" those ambiguities. ${ }^{214}$

In truth, however, neither the form memorandum nor the Will Wilson letter is ambiguous. ${ }^{215}$ To characterize them as "inartful" or at worst "careless clerical drafting," as the govern-

${ }^{209}$ See note 87 supra. See also United States v. Schullo, 363 F. Supp. 246, 252 (D. Minn. 1973); United States v. Ciamacco, 362 F. Supp. 107, 113 (W.D. Pa.), aff'd, 491 F.2d 751 (3d Cir. 1973); United States v. Askins, 351 F. Supp. 408, 418 (D. Md. 1972).

${ }^{210}$ United States v. King, 478 F.2d 494, 502 (9th Cir.), cert. denied, 414 U.S. 846 (1973).

${ }^{211}$ In re Alperen, 355 F. Supp. 372, 374 (D. Mass. 1973), aff'd, 478 F.2d 194 (Ist Cir. 1973); United States v. DeCesaro, 349 F. Supp. 546, 548 (E.D. Wis. 1972); United States v. Cantor, 345 F. Supp. 1352, 1355 (E.D. Pa.), aff'd, 470 F.2d 890 (3d Cir. 1972); United States v. LaGorga, 336 F. Supp. 190, 195 (W.D. Pa. 1971), modified, 340 F. Supp. 1397 (1972).

212 United States v. Becker, 461 F.2d 230, 234-36 (2d Cir. 1972), vacated, 417 U.S. 903 (1974); United States v. D'Amato, 340 F. Supp. 1020 (E.D. Pa. 1972).

${ }^{213}$ United States v. Bowdach, 366 F. Supp. 1368, 1371 (S.D. Fla. 1973); United States v. Whitaker, 343 F. Supp. 358, 360 (E.D. Pa. 1972), rev'd on other grounds, 474 F.2d 1246 (3d Cir.), cert. denied, 412 U.S. 953 (1973); see United States v. Fox, 349 F. Supp. 1258, 1262 (S.D. Ill. 1972) ("form over substance"); United States v. Kohne, 347 F. Supp. 1178, 1182 (W.D. Pa. 1972) ("form over substance").

${ }^{214}$ United States v. Stanley, 360 F. Supp. $1112,1113-14$ (N.D. Ga. 1973); United States v. Doolittle, 341 F. Supp. 163, 167-68 (M.D. Ga. 1972).

${ }^{215}$ In contrast to the few courts which have described the form memorandum addressed to Will Wilson as ambiguous, see note 214 supra, other courts have regarded its import as perfectly clear. Chavez $I, 478$ F.2d at 514-15; United States v. Sklaroff, 362 F. Supp. 478, 479-80 (S.D. Fla. 1973), rev'd, 500 F.2d 1183 (5th Cir. 1974); United States v. Vasquez, 348 F. Supp. 532, 536 (C.D. Cal. 1972); United States v. Whitaker, 343 F. Supp. 358, 360 (E.D. Pa. 1972), rev'd on other grounds, 474 F.2d 1246 (3d Cir.), cert. denied, 412 U.S. 953 (1973); see United States v. Cantor, 328 F. Supp. 561, 563-64 (E.D. Pa. 1971), aff'd, 470 F.2d 890 (3d Cir. 1972). The courts also recognize that the 
ment did before the Supreme Court, ${ }^{216}$ strains the limits of permissible advocacy. The only basis for characterizing these documents as ambiguous are the flatly contradictory assertions in the government's affidavits.

Several defendants in the lower courts objected to the use of these affidavits. ${ }^{217}$ One kind of objection concerned the nature of the government's proof: that affidavits were an incompetent form of evidence because their use eliminated any opportunity for cross-examination, ${ }^{218}$ and that the affidavits included self-serving and legally conclusory statements. ${ }^{219}$

Most lower courts which considered these objections rejected them without hesitation. They regarded the use of affidavits as proper, in some cases citing rule 12(b)(4) of the Federal Rules of Criminal Procedure, which explicitly permits the resolution of collateral issues on the basis of affidavits. ${ }^{220}$ The courts

assertions of the "Will Wilson" letter are explicit in their meaning. United States v. Stanley, 360 F. Supp. 1112, 1114-15 (N.D. Ga. 1973); Focarile, 340 F. Supp. at 1059-60; see United States v. King, 478 F.2d 494, $499-502$ (9th Cir.), cert. denied, 414 U.S. 846 (1973). On the other hand, at least one court has taken the position that, standing alone, the government's Title III documents satisfactorily identify the Attorney General as the authorizing officer. United States v. Ceraso, 467 F.2d 647, 652-53 (3d Cir. 1972). See United States v. Ciamacco, 362 F. Supp. 107, 113 (W.D. Pa.), aff'd, 491 F.2d 751 (3d Cir. 1973). And, even after considering the Title III documents and the affidavits, some courts have ruled that the Attorney General did not authorize a Title III application, but only specially designated Will Wilson. United States v. Brown, 351 F. Supp. 38, 40 (W.D.N.C. 1972); United States v. Casale, 341 F. Supp. 374 (M.D. Pa.), rev'd sub nom. United States v. Ceraso, 467 F.2d 647 (3d Cir. 1972). Despite these conflicting interpretations of the form memorandum addressed to Will Wilson, simply reviewing its text makes its purpose perfectly clear. Compare note 20 supra with 18 U.S.C. § $2516(1)$ (1970), quoted in note 6 supra. See also note 182 supra \& accompanying text, and notes 16, 17, 21 supra. Furthermore, the government itself attached the same interpretation to its Title III documents and, indeed, insisted upon that interpretation vociferously, until it was compelled to construct a new explanation for the authorization process to save its Title III proceedings from suppression. United States v. Sklaroff, 360 F. Supp. 353, 354-61 (N.D. Ga. 1973). Finally, the Solicitor General conceded before the Supreme Court that the form memorandum indicated not that the Attorney General had authorized the application, but that "Wilson himself was designated to review and authorize the application." Chavez $I I$, 416 U.S. at 582 (opinion of Douglas, J.). See Giordano Brief, supra note 17, at 6-7.

${ }^{216}$ Giordano Brief, supra note 17 , at 71 .

${ }^{217}$ See, e.g., United States v. Ceraso, 467 F.2d 647, 652-53 (3d Cir. 1972); United States v. Schullo, 363 F. Supp. 246, 251-53 (D. Minn. 1973); In re Alperen, 355 F. Supp. 372, 374 (D. Mass.), aff'd, 478 F.2d 194 (1st Cir. 1973).

${ }^{218}$ United States v. Doolittle, 341 F. Supp. 163, 166 (M.D. Ga. 1972).

${ }^{219}$ United States v. Bowdach, 474 F.2d 812, 813-14 (5th Cir. 1973); United States v. Consiglio, 342 F. Supp. 556, 558 (D. Conn. 1972). In the case of affidavits filed by subordinate officials, some defendants also objected to hearsay statements of the affiants' authority to act. Id.

${ }^{220}$ See In re Alperen, 355 F. Supp. 372, 374 n.3 (D. Mass.), aff'd, 478 F.2d 194 (1st Cir. 1973). 
also rejected the demand for cross-examination, reasoning that the authorization issue only affected the admissibility of the interceptions and that the sixth amendment right of confrontation does not apply to such a preliminary issue. ${ }^{221}$

By and large, these grounds were correct as far as they went. And it is easy to understand why lower court judges would be reluctant to order testimony in such cases. The inconvenience to the officials involved obviously would be enormous, and a refusal to proceed on the basis of the government's affidavits might reflect adversely on the integrity or credibility of the affiants, "our nation's highest law enforcement officials,"222 something any court would hesitate to do. Finally, there was undoubtedly a degree of truth to the government's contention that at least some defendants were demanding oral testimony by Justice Department officials largely in order to delay their trials. ${ }^{223}$

However, by permitting the government to use its affidavits, the lower courts overlooked the self-serving and conclusory nature of their contents. ${ }^{224}$ Also, the text of the affidavits left many questions unanswered. ${ }^{225}$ For these reasons one court of appeals remanded several authorization cases for a full evidentiary hearing, ${ }^{226}$ which revealed several facts about the

${ }^{221}$ United States v. Consiglio, 342 F. Supp. 556, 559-60 (D. Conn. 1972); United States v. Doolitcle, 34 l F. Supp. 163, 168-69 (M.D. Ga. 1972); cf. United States v. Matlock, 415 U.S. 164, 172-75 (1974). The rejecting courts also cited cases, some involving the authorization question, in which other courts had accepted similar documentary evidence, United States v. Mainello, 345 F. Supp. 863,878 n.54 (E.D.N.Y. 1972); United States v. Consiglio, supra at 560. At least some of these precedents in which other courts relied on affidavits, however, involved situations in which the court had demanded affidavits sua sponte or in which defendants had acceded to their use. See, e.g., United States v. Pisacano, 459 F.2d 259, 262-63 (2d Cir. 1972), vacated, 417 U.S. 903 (1974); United States v. Robinson, 468 F.2d 189, 191 (5th Cir. 1972), remanded, 412 F.2d 973 (5th Cir. 1973) (en banc); $f$. United States v. Curreri, 363 F. Supp. 430, 434-35 (D. Md. 1973).

${ }^{222}$ United States v. Bowdach, 366 F. Supp. 1368, 1373 (S.D. Fla. 1973).

${ }^{223}$ United States v. Doolittle, 341 F. Supp. 163, 166 (M.D. Ga. 1972).

${ }^{224}$ In the Marder hearing, defense counsel objected when former Assistant Attorney General Will Wilson was asked whether the Attorney General had ever authorized him to approve applications, on the grounds that the question called for a legal conclusion. Marder Record, supra note 14, at 266. Judge Mehrtens recognized that the objection was sound, but permitted Wilson to answer on the grounds that, as an attorney, his legal opinion was admissible. Id.

225 These questions arose largely because of the conclusory nature of the affidavits. See, e.g., United States v. Bowdach, 474 F.2d 812, 813-14 (5th Cir. 1973); United States v. Vasquez, 348 F. Supp. 532, 535-36 (C.D. Cal. 1972). See also United States v. Brick, 502 F.2d 219, 226 (8th Cir. 1974) (Bright, J., concurring).

${ }^{226}$ United States y. Robinson, 472 F.2d 973 (5th Cir. 1973) (en banc); see note 
authorization process which the affidavits had not disclosed. ${ }^{227}$ But this hearing only satisfied defense objections to the form of the government's after-the-fact representations. It did not overcome the second type of objection which defendants raised in the lower courts: that the government should not be permitted to disclaim on any kind of after-the-fact basis the explicit representations by which it had obtained Title III orders. In one case the defendants justified this assertion by invoking estoppel doctrine. ${ }^{28}$ More commonly, however, objections of this sort relied on the well-established rule that the validity of a warrant must be determined solely on the basis of the information presented to the issuing magistrate. ${ }^{229}$

\section{Estoppel}

The doctrine of equitable estoppel does not properly apply to the government's change in positions on the Title III authorizations. ${ }^{230}$ In United States $v$. Consiglio, the one case in which

14 supra. See also United States v. Sklaroff, 360 F. Supp. 353, 354-61 (N.D. Ga. 1973). Another evidentiary hearing was ordered in a subsequent case, United States $v$. Bowdach, 474 F.2d 812 (5th Cir. 1973).

${ }^{227}$ Besides demonstrating that the various officials involved in the authorization process were ignorant or confused about one another's role, see notes 44 \& 169 supra, the testimony revealed that, at Sol Lindenbaum's direction, the Attorney General's secretaries would occasionally initial the form memoranda addressed to Will Wilson, Marder Record, supra note 14, at 213-14; and that on one occasion, apparently without authorization, then Deputy Attorney General Richard Kleindeinst also did so. Id. $59,72,226$.

${ }^{228}$ United States v. Consiglio, 342 F. Supp. 556 (D. Conn. 1972).

${ }^{229}$ Aguilar v. Texas, 378 U.S. 108, 109 n.1 (1964); Giordenello v. United States, 357 U.S. 480,486 (1958).

${ }^{230}$ Equitable estoppel, or estoppel in pais, can be described as estoppel by misrepresentation, A.M.P., Inc. v. United States, 389 F.2d 448, 452 (C.t. Cl.), cert. denied, 391 U.S. 964 (1968); see Henshaw v. Bissell, 85 U.S. (18 Wall.) 255, 271 (1873); Investors Syndicate of America, Inc. v. Indian Rocks Beach, 434 F.2d 871, 879 (5th Cir. 1970). The doctrine is said to apply when, knowing the true facts, the party to be estopped misrepresents those facts to another with the intention that that other should rely thereon and the other, being ignorant of the true facts, pursues a certain course of conduct in reliance upon the misrepresentation, to his detriment. See Hecht v. Harris, Upham \& Co., 430 F.2d 1202, 1208 (9th Cir. 1970); Minerals \& Chemicals Philipp Corp. v. Milwhite Co., 414 F.2d 428, 430 (5th Cir. 1969); Gestuvo v. District Director, 337 F. Supp. 1093, 1101-02 (C.D. Cal. 1970); United States v. Wilcox, 258 F. Supp. 944, 949 (N.D. Iowa 1966). In contrast to the doctrine of waiver, which can arise by unilateral conduct, equitable estoppel requires conduct by both parties. Bealle v. Nyden's, Inc., 245 F. Supp. 86, 93-95 (D. Conn. 1965); see Comment, W'aiver and Estoppel, 20 Baylor L. Rev. 325 (1968). "In a strict and technical sense an estoppel arises only when a misrepresentation has prejudiced another who has relied upon it." Deitrich v. Greaney, 309 U.S. 190, 197 (1940). The policies underlying the estoppel doctrine are said to include preventing fraud and barring the party to be estopped 
defendants raised the doctrine, the district court rejected it because the defendants could show no reliance upon the government's original representations. ${ }^{231}$ Consequently, reasoned the court, when the government offered a new version of the facts, the defendants suffered no prejudice.

This reasoning was correct. Furthermore, there is some question whether estoppel ever properly applies against the government in criminal cases. ${ }^{232}$ On the other hand, the two district judges who issued the wiretap orders involved in Consiglio did act in reliance upon the government's representations that Will Wilson had authorized the applications. ${ }^{23}$ The Consiglio court refused to hold the government to its original representations on that basis, reasoning that the government had obtained no benefit from the misstatements and therefore had worked no "material fraud" on the court. ${ }^{234}$ Of course, to the extent the government did obtain some institutional benefit by conducting its authorization procedures in a manner different than that mandated by Congress, the court's analysis is wrong. ${ }^{235}$ Furthermore, estoppel does not necessarily require that the act

from receiving an unconscionable advantage by disavowing prior misrepresentations upon which an innocent party reasonably relied. Dickerson v. Colgrove, 100 U.S. 578, 580-81 (1879); see Morgan v. Chicago \& A.R.R., 96 U.S. 716, 720 (1877). The misrepresentations must be knowingly or at least negligently made; an honest mistake will not justify imposition of the doctrine. Broussard v. Patton, 466 F.2d 816, 820 (9th Cir. 1972), cert. denied, 410 U.S. 942 (1973); of. Carson v. Hyatt, 118 U.S. 279 (1886) (inadvertantly mispleading the location of the defendant's residence will not bar plaintiff from proving the true residence at trial.)

${ }^{231}$ United States v. Consiglio, 342 F. Supp. 556, 560-61 (D. Conn. 1972).

${ }^{232}$ The Consiglio court found it unnecessary to decide this issue. Id. at 561. Some authorities flatly assert that estoppel should not apply to the government in criminal cases. Dix v. Rollins, 413 F.2d 711, 716 (8th Cir. 1969); State v. Abbott, 64 N.J. Super. 191, 203, 165 A.2d 537, 543 (1960), rev'd on other grounds, 36 N.J. 63, 174 A.2d 881 (1961); see Comment, Applying Estoppel Principles in Criminal Cases, 78 Y ALE L.J. 1046 (1969). Other cases suggest that the doctrine will apply to the government under appropriate circumstances, see Comment, Never Trust A Bureaucrat: Estoppel Against the Government, 42 S. CAL. L. REv. 391, 395-96 (1969); see also Kennedy v. MendozoMartinez, 372 U.S. I44, 157 (1963) (dictum); Illinois ex rel. Gordon v. Campbell, 329 U.S. 362, 369 (1946); United States v. Lazy FC Ranch, 481 F.2d 985, 988 (9th Cir. 1973); Brandt v. Hickel, 427 F.2d 53, 56-57 (9th Cir. 1970). Several courts have described as among those circumstances representations made by government officials with authority to bind the government while acting within the scope of their employment. Atlantic Richfield Co. v. Hickel, 432 F.2d 587, $591-92$ (10th Cir. 1970); see Parker v. United States, 461 F.2d 806, 809 (Ct. Cl. 1972); Berger, Estoppel Against the Government, 21 U. CHI. L. Rev. 680, 687-88 (1954).

${ }^{233} 342$ F. Supp. at 557-58.

${ }^{234} I d$. at 560 n.6.

${ }^{235}$ See text accompanying notes 176-84 supra. 
of reliance which triggers the doctrine necessarily benefit the party estopped. ${ }^{236}$

More importantly, the Consiglio court failed to consider that the government made its initial representations under oath in the course of a judicial proceeding. Those circumstances invite application of judicial estoppel or "estoppel by oath." 237 In such cases no showing of reliance by another is necessary to bind the party estopped; ${ }^{238}$ the doctrine "is based solely on public policy which upholds the sanctity of an oath and precludes a party who has made a sworn statement, even

${ }^{236}$ Dickerson v. Colgrove, 100 U.S. 578, 581 (1879). Of course, the receipt of benefits often does occur in equitable estoppel situations, see, e.g., FPC v. Colorado Interstate Gas Co., 348 U.S. 492, 502 (1955); Weir v. United States, 474 F.2d 617, 622 (Ct. Cl.), cert. denied, 414 U.S. 1066 (1973); United States v. Kassan, 208 F. Supp. 858, 861 (S.D. Cal. 1962).

${ }^{237}$ The doctrine sometimes is also described as a rule precluding the adoption of inconsistent positions in judicial proceedings, see Gottesman v. General Motors Corp., 222 F. Supp. 342 (S.D.N.Y. 1963), cert. denied, 379 U.S. 882 (1964); Note, The Doctrine of Preclusion Against Inconsistent Positions in Judicial Proceedings, 59 Harv. L. Rev. 1132 (1946). Its purpose is "to prevent a litigant from leading a court to find a fact one way in one proceeding, and then simply because [the litigant's] interests have changed lead the court to find another way in a subsequent proceeding." Gottesman v. General Motors Corp., supra at 344; see Colonial Refrigerated Transp. Inc. v. Mitchell, 403 F.2d 541, 550 (5th Cir. 1968); Buder v. United States, 332 F. Supp. 345, 349-50 (E.D. Mo. 1971). Some courts suggest the doctrine does not apply unless the party against whom it is invoked successfully maintained the position initially adopted to the detriment of the adversary parties. Eads Hide \& Wool Co. v. Merrill, 252 F.2d 80, 84 (10th Cir. 1958); Scarano v. Central R.R., 203 F.2d 510, 513 (3d Cir. 1953); Parker v. Sager, 174 F.2d 657, 661 (D.C. Cir. 1949). Nor does it appear that the doctrine applies to purely legal claims as opposed to factual assertions, at least until such time as all reasonable certainty as to which legal claim is correct disappears. New Amsterdam Cas. Co. v. Waller, 323 F.2d 20, 24 (4th Cir. 1963), cert. denied, 376 U.S. 963 (1964); Robinson v. Chicago Great Western Ry., 144 F. Supp. 713, 717 (W.D. Mo. 1956). But see Jett v. Zink, 474 F.2d 149, 154-55 (5th Cir.), cert. denied, 414 U.S. 854 (1973) (party which initially successfully argued that suit was in personam cannot subsequently argue that action was only quasi-in rem); W.T. Jones \& Co. v. Foodco Realty, Inc., 318 F.2d 881, 888-89 (4th Cir. 1963) (SBA cannot simultaneously assert common law priority rule and prior statutory lien).

${ }^{238}$ Some authorities suggest that even the doctrine of judicial estoppel should not apply unless the party seeking to invoke the doctrine in some way relied to his detriment upon the position initially taken in a judicial proceeding, see, e.g., Roth v. McAllister Bros., 316 F.2d 143, 145 (2d Cir. 1963); Collier v. Granger, 258 F. Supp. 717, 719-20 (S.D.N.Y. 1966). Such a restriction might be appropriate when the party seeking to invoke the doctrine was not himself party to the first judicial proceeding. See Hobbs v. McLean, 117 U.S. 567, 580-81 (1886); Annot., '113 A.L.R. 925 (1938). However, the restriction essentially reflects a confusion between the elements and purpose of estoppel in pais, see note 230 supra, and the nature of judicial estoppel, which serves to guard the dignity of judicial proceedings and the sanctity of the oath. Note, supra note 237 , at 1133 . In any case it is clear that judicial estoppel applies in situations in which the injured party has in no way acted in reliance upon the position initially taken, although a detriment did occur in that the court acted favorably towards 
in another litigation, from repudiating the same when he thinks it is to his advantage to do so."239

Some authorities suggest that even estoppel by oath does not apply when the party to be estopped is the government. ${ }^{240}$ The rationale of this position is that courts invoke the estoppel doctrine in order to serve public policy; ${ }^{241}$ when the government is involved, the public policies which estoppel advances must be balanced against the public interests which application of the doctrine will frustrate. ${ }^{242}$ Particularly in criminal cases, runs the argument, the overwhelming public interests in the conviction of offenders outweigh the interests which estoppel serves. ${ }^{243}$

This argument may have some merit when applied to traditional estoppel. It is of considerably less force when applied to sworn government representations made in judicial proceedings. Theoretically, at least, the government is subject to the same standards of accuracy and truthfulness as are other parties before the courts. ${ }^{244}$ Justice Douglas asserted in his Chavez dissent that " $[\mathrm{t}]$ he failure of a prosecution in a particular case pales in comparison with the duty of this Court to nourish and enhance respect for the evenhanded application of the law." 245 Furthermore, as one court pointed out, "it is beyond rational dispute" that the submission by a private party of false and misleading documents similar to the government's Title III documents "would be treated as nothing less than contempt of court." ${ }^{246}$ Of course, it is unlikely that any court would

the party against whom the doctrine is now invoked. See, e.g., Illinois ex rel. Gordon v. Campbell, 329 U.S. 362, 369 (1946); Jett v. Zink, 474 F.2d 149 (5th Cir.), cert. denied, 414 U.S. 854 (1973); Kent Homes Inc. v. United States, 279 F. Supp. 650, 659 (D. Kan. 1967).

${ }^{239}$ Holt v. Southern Ry., 51 F.R.D. 296, 298-99 (E.D. Tenn. 1969); accord, United States v. Certain Land and Interests in Property, 225 F. Supp. 338, 340-41 (M.D. Tenn. 1964). Although the district court in the latter case described the doctrine as a peculiarity of Tennessee law, $i d$. at 340 , the rule of judicial estoppel is, in fact, one of general application. See Note, supra note 237, at 1132-33; cases cited in note 237 supra.

But see Hatten Realty Co. v. Baylies, 42 Wyo. 69, 86-94, 290 P. 561, 566-68 (1930).

240 Note, supra note 237 , at 1136 .

${ }^{241}$ See text accompanying note 239 supra.

242 Note, supra note 237, at 1136. See note 232 supra.

${ }^{243}$ For an interesting attempt to balance these public interests while still permitting an estoppel defense in criminal cases, see Comment, YALE L.J., supra note 232.

${ }^{244}$ Ritter v. United States, 28 F.2d 265, 267 (3d Cir. 1928); see Berger, supra note 232, at 707; 16 Geo. WASh. L. Rev. 273, 274 (1948).

${ }^{245}$ Chavez II, 416 U.S. at 599 (opinion of Douglas, J.).

${ }^{246}$ United States v. Robinson, 359 F. Supp. 52, 57 (S.D. Fla. 1973), rev'd per curiam, 496 F.2d 225 (5th Cir. 1974) (en banc). 
hold senior Justice Department officials in contempt on this basis; for that very reason, it should be under an even greater obligation accurately to represent material facts. It was partly for this reason that the court of appeals in Chavez imposed the suppression sanction. ${ }^{247}$

\section{Analogy to Search Warrant Cases}

Although no court adopted the judicial estoppel approach, a few lower courts did, refuse to consider the government's after-the-fact affidavits by analogy to the rule that search warrants cannot be justified except by information presented to the issuing magistrate. ${ }^{248}$ The rationale for this rule is the fourth amendment requirement that a neutral and detached magistrate must decide to issue the warrant on the basis of the sworn statement of facts and circumstances justifying the intrusion which a search involves, ${ }^{249}$ and that consequently the government cannot supplement its showing of probable cause by offering additional evidence after a search has occurred. ${ }^{250}$ Functionally at least, this rule approximates the doctrine of estoppel; but it is based on the Constitution rather than on public policy. ${ }^{251}$ Therefore, the courts are not free to balance the interests served by the search warrant rule against those which post-issuance demonstrations of probable cause would advance.

No provision of the Constitution requires an issuing judge to identify the authorizing officer in a Title III order; that requirement is only statutory in nature. Thus, whether a reviewing court should consider any information besides that available to the issuing judge must depend on the degree of

${ }^{247}$ Chavez 1,478 F.2d at 517.

248 United States v. Boone, 348 F. Supp. 168, 170 (E.D. Va. 1972), rev'd, 499 F.2d 551 (4th Cir. 1974); Focarile, 340 F. Supp. at 1043-44, 1057-58. Another court expressed disapproval of considering the after-the-fact evidence which resulted from the Marder hearing, but did so pursuant to the explicit instructions of the court of appeals. United States v. Stanley, 360 F. Supp. 1112, 1113 n.3 (N.D. Ga. 1973); United States v. Sklaroff, 360 F. Supp. 353, 361 (N.D. Ga. 1973); see United States v. Acon, 377 F. Supp. 649, 652 (W.D. Pa. 1974) (dictum).

${ }^{249}$ Shadwick v. Tampa, 407 U.S. 345 (1972); Coolidge v. New Hampshire, 403 U.S. 443 (1971).

${ }^{250}$ See note 229 supra. Note, however, that in the search warrant case, the government only seeks to supplement its demonstration of probable cause; in the Title III situation, the government seeks to make a showing which is inconsistent with its earlier representations.

251 Aguilar v. Texas, 378 U.S. 108 (1964). 
importance Congress attached to the accuracy of the initial finding. As previously described, substantial evidence exists that Congress regarded the accurate identification of the authorizing officer in the first instance to be a major safeguard within the framework of the statute. ${ }^{252}$ In Chavez, by contrast, five members of the Supreme Court took a very different view of the identification requirements. ${ }^{253}$ Although Congress saw fit to write those requirements into the text of the statute itself, the Supreme Court majority relegated them to a largely hortatory status. ${ }^{254}$ Consequently, although the Court never confronted the issue, it seems unlikely that the majority would have attached much importance to what evidence reviewing courts considered when deciding the accuracy of Title III findings on authorization.

However, the point is that although the appellees in Chavez attempted to raise this issue and although its disposition in accordance with the estoppel argument or by analogy to the search warrant rule probably would have required a different result, the Court simply ignored it. The Court never even considered whether after-the-fact affidavits should be allowed; both the majority and the dissent simply adopted the factual assumption of the lower courts that the Attorney General had personally authorized the relevant Title III application, without examining the grounds for that assumption or the propriety of its use.

\section{B. The Legal-Factual Issue: What Did the Attorney General Really Do?}

The Supreme Court compounded its failure to decide the evidentiary issues created by the government's use of afterthe-fact affidavits by its additional failure to consider the crucial substantive issue which that after-the-fact evidence concerned:

${ }^{252}$ See text accompanying notes 118-22 supra; Chavez I, 478 F.2d at 516-17; Focarile, 340 F. Supp. at 1053-57.

${ }^{253}$ See text accompanying notes $112-17$ supra.

${ }^{254}$ After declaring that the court of appeals erred by suppressing Title III evidence in Chavez on the grounds of misidentification, Justice White commented:

Though we deem this result to be the correct one under the suppression provisions of Title III, we also deem it appropriate to suggest that strict adherence by the Government to the provisions of Title III would nonetheless be more in keeping with the responsibilities Congress has imposed upon it when authority to engage in wiretapping or electronic surveillance is sought. 416 U.S. at 580. 
Did the Attorney General's actions relating to the form memorandum addressed to Will Wilson constitute authorization within the meaning of section 2516(1)? Even if one takes into account the after-the-fact evidence which the government offered in Chavez and other cases, a substantial question still exists whether the Attorney General properly completed the discretionary act which the statute requires. Under the provisions of section 2516(1), the Attorney General personally can act with respect to a Title III application in two different ways: Either he can personally decide to authorize the application, or he can specially designate an Assistant Attorney General to perform that discretionary act. In Giordano the Supreme Court ruled that if the Attorney General takes no personal action whatsoever concerning a Title III application, the resulting court order is void. In Chavez the Court neglected to consider what the legal effect of the Attorney General's personal actions actually was.

To be sure, the after-the-fact evidence which the government submitted suggests that the Attorney General personally reviewed the file concerning the Chavez application and that he personally initialed the form memorandum addressed to Will Wilson. ${ }^{255}$ And the Attorney General's own sworn statements assert that the legal effect of his actions was to accomplish the discretionary act which section 2516(1) requires. ${ }^{256}$ However, putting aside any issue of credibility, ${ }^{257}$ such assertions do not resolve the issue as a matter of law. Some lower courts which accepted the Attorney General's statements that he personally initialed the form memorandum disagreed with his assertions concerning its legal effect. ${ }^{258}$ Certainly, to the extent the Attorney General's assertions concerning the legal effect of his actions represent his expert opinion, they are not binding on the courts. ${ }^{259}$ Nor does it appear that they are any more conclusive as statements of his intent when he initialed the form memorandum. In either case a question remains for adjudica-

${ }^{255}$ The record in Giordano and Chavez consisted not only of the affidavits which the government had submitted to the lower courts in those cases, but also the transcript of the Marder hearing. Giordano Brief, supra note 17, at $5 \mathrm{n} .2$.

${ }^{256}$ See note 87 supra; Marder Record, supra note 14, at 36-57.

${ }^{257}$ Cf. United States v. Schullo, 363 F. Supp. 246, 253 (D. Minn. 1973).

${ }_{258}$ United States v. Boone, 348 F. Supp. 168, 170-71 (E.D. Va. 1972), rev'd, 499 F.2d 551 (4th Cir. 1974); United States v. Casale, 341 F. Supp. 374, 375 (M.D. Pa.), rev'd sub nom. United States v. Ceraso, 467 F.2d 647 (3d Cir. 1972).

${ }^{259}$ See United States v. Nixon, 418 U.S. 683, 703-05 (1974). 
tion: Did the Attorney General's actions satisfy the statutory requirements?

The Supreme Court did not recognize this issue. ${ }^{260}$ It simply assumed that the Attorney General had satisfied the statute, and decided Chavez on that basis. ${ }^{261}$ However, there are at least two aspects of the Attorney General's actions which appear to fall short of the statute's requirements, either one of which might require rejecting the Chavez order for lack of authorization.

The first aspect concerns Congress' purpose. The legislative history strongly suggests that Congress regarded the authorization requirement as a means of ensuring restraint in the use of electronic surveillance. ${ }^{262}$ Congress intended that the Attorney General or one of his nine Assistants personally should take responsibility for devising the Justice Department's policies for invoking Title III procedures, and should apply those policies in each and every case. ${ }^{263}$ The Supreme Court recognized this congressional purpose when it commented in Giordano that the authorization requirement, as Congress conceived of it, "would inevitably foreclose resort to wiretapping in various situations where investigative personnel would otherwise seek intercept authority from the court and the court would very likely authorize its use."264

It is equally clear what policies of restraint Congress had in mind. Although it regarded court-authorized electronic interceptions as constitutionally permissible, Congress did not want them employed in every case which technically fell within the parameters of the statute. The primary justification for

${ }^{260}$ It is important to note that the only two courts which explicitly considered this issue, one on the basis of the Marder testimony, see note 14 supra, concluded that the Attorney General did authorize Title III applications by initialling the form memorandum and did so in a manner which satisfied the statute. United States v. Bowdach, 366 F. Supp. 1368 (S.D. Fla. 1973); United States v. Whitaker, 343 F. Supp. 358 (E.D. Pa. 1972), rev'd on other grounds, 474 F.2d 1246 (3d Cir.), cert. denied, 412 U.S. 953 (1973). However, in both cases, the courts reached that conclusion by ignoring the explicit text of the form memorandum and by relying on the conclusory affidavits which had caused the court of appeals in Bowdach to remand the case for an evidentiary hearing, see note 226 supra, as well as on the equally conclusory testimony of the Marder witnesses. United States v. Bowdach, supra at 1371-72; United States v. Whitaker, supra at 360.

${ }^{261}$ See note 203 supra.

${ }^{262}$ See text accompanying notes 62-64 supra.

${ }^{263}$ United States v. King, 478 F.2d 494, 503 (9th Cir.), cert. denied, 414 U.S. 846 (1973); see note 181 supra.

${ }^{264}$ Giordano II, 416 U.S. at 528. 
electronic surveillance was the necessity to combat organized crime. ${ }^{265}$ Congress wanted the Attorney General or his designated Assistant Attorney General to determine in each case whether the use of Title III was appropriate in light of the nature of the offense or the identity of the offenders. ${ }^{266}$

The Attorney General himself did not approve or disapprove applications on this basis. He repeatedly stated that his only concern was that the application and supporting papers satisfy the statutory standards of probable cause and necessity. ${ }^{267}$ Indeed, the government argued in some lower court cases that it did not matter how carefully the Attorney General conducted this review because, ultimately, the issuing judge would make those same determinations. ${ }^{268}$

${ }^{265}$ The Senate Report flatly states that the major purpose of Title III is to combat organized crime. S. REP., supra note 3, at 2157. Furthermore, much of the Report is devoted to a description of the dangers which organized crime poses. Id. 2157-61. See also A.B.A. Standards Relating to Electronic Surveillance, supra note 4, at 260-78. Control of organized crime is also listed in the Report as one determinant of which federal crimes would be identified in $\$ 2516(1)$ as appropriate for Title III interceptions. S. REP., supra note 3, at 2186. Most importantly, Congress included in the body of the statute itself an explicit finding that the interception of communications relating to organized criminal activities was "an indispensible aid to law enforcement and the administration of justice." Pub. L. 90-351, Title III, $\S 801$ (c), 82 Stat. 211 (also in 18 U.S.C. $\$ 2510$ note (1970)). See United States v. King, 478 F.2d 494, 50̄-06 (9th Cir.), cert. denied, 414 U.S. 846 (1973).

266 Giordano II, 416 U.S. at 527; United States v. King, 478 F.2d 494, 503 (9th Cir.), cert. denied, 414 U.S. 846 (1973).

${ }^{267}$ Marder Record, supra note 14, at 63-64, 70-71, 74. Although the affidavits of John Mitchell and Sol Lindenbaum make reference to the Attorney General's policies in relation to the use of Title III, those policies were never promulgated in any formal sense, see note 44 supra. Rather, "the guidelines that actually evolved consisted of decisions made on previous applications, which served as precedents to guide Mr. Lindenbaum's actions in the cases in which he acted on behalf of the Attorney General." Giordano Brief, supra note 17, at $\mathbf{5 5}$ n.38.

At the Marder hearing, Lindenbaum and Petersen testified that the Attorney General's policies included limiting the use of Title III to organized crime or other serious cases. Marder Record, supra note 14, at 136, 220-21. But Lindenbaum's testimony suggested that whether the use of Title III was necessary or appropriate in an individual case was not a consideration after the first few proceedings, id. 220, and the Attorney General, when asked if he made a determination whether the use of electronic interceptions was necessary in each case, replied that he reviewed the determination of the Criminal Division as to necessity and "obviously, there was a need or otherwise the application would not have been sent up to me." Id. 67.

None of this evidence suggests that, as an institution, the Department of Justice failed carefully to review Title III applications, or that the Attorney General did not review the files as well. $I d .63,119,121$. What it does suggest is that the Attorney General did not formulate a policy of restraint and personally decide in each case whether the circumstances justified the extraordinary intrusions permitted by electronic surveillance techniques.

${ }^{268}$ See, e.g., United States v. Narducci, 341 F. Supp. 1107, 1110 (E.D. Pa. 1972). See also Giordano Brief, supra note 17 , at $30-33,43-46$. This view differs remarkably 
Of course, questions may exist concerning the extent to which courts may properly review the mental processes of an executive branch officer when he exercises quasi-judicial functions, ${ }^{269}$ but some lower courts did conclude that Congress intended the authorizing officer to conduct a "sentient review" of each Title III application, ${ }^{270}$ and two judges made a determination whether such a review occurred. ${ }^{271}$ Moreover, in United States v. United States District Court the government conceded that courts could properly review the criteria by which the Attorney General determined that domestic security considerations required the employment of electronic surveillance. ${ }^{272}$ Indeed, in that case Justice White argued in a concurring opinion that the reasons for the Attorney General's authorization of those wiretaps, as indicated by his own affidavit, did not satisfy the statutory criteria upon which the government asserted its authority to act without judicial approval. ${ }^{273}$

from the views of Senator John McClellan, one of Title III's chief proponents. Commenting upon the experience of the first year following enactment of Title III, Senator McClellan asserted that "the opponents of this legislation who predicted widespread and promiscuous use of wiretaps and bugs by law enforcement authorities are being proven wrong in their prognostications." 115 Cong. REC. 23,238 (1969). But see note 13 supra. He also noted that the prosecutorial screening process established by the statute appeared to be having a healthy effect on the number of applications submitted to the courts, and stated that "[o]ur thought was that mandating prosecutor involvement in the warrant process would strengthen it by guaranteeing that the decision to use these techniques would be preceded by a careful law enforcement screening process." Id. 23,240.

${ }^{269}$ See United States v. Consiglio, 342 F. Supp. 556, 560 (D. Conn. 1972); United States v. Doolittle, 341 F. Supp. 163, 169 (M.D. Ga. 1972) (quoting United States v. Morgan, 313 U.S. 409, 422 (1941)). But see Citizens to Preserve Overton Park v. Volpe, 401 U.S. 402 (1971).

${ }^{270}$ United States v. Narducci, 341 F. Supp. 1107,1113 (E.D. Pa. 1972). See also text accompanying notes 263-64 supra.

${ }^{271}$ United States v. O'Neill, 497 F.2d 1020, 1026 (6th Cir. 1974); United States v. Bowdach, 366 F. Supp. 1368, $1371-72$ (S.D. Fla. 1973). Even with respect to discretionary decisions by judges themselves, the federal courts have considered whether the deciding judge applied the appropriate standards. United States v. Nixon, 418 U.S. $683,697-702$ (1974) (whether district judge improperly applied criteria under rule 17(c) of the Federal Rules of Criminal Procedure); United States i. Tucker, 404 U.S. 443 (1972) (whether district judge improperly relied during sentencing upon prior counselless convictions); United States v. Wiley, 267 F.2d 453 (7th Cir. 1959) (whether district judge properly exercised discretion in refusing to consider probation because defendant pleaded not guilty and demanded trial).

272 Brief for Petitioner at 21-23, United States v. United States District Court, 407 U.S. 297 (1972). The government conceded that the Attorney General's determination was properly subject to judicial review, but argued that such a review should be strictly limited to whether the Attorney General's determination was arbitrary or capricious. Id.

${ }^{273} 407$ U.S. at 341 (White, J., concurring). 
If Justice White had subjected the documentation of the Attorney General's purported approval of Title III applications to the same close scrutiny in Chavez, he might well have concluded that those documents did not demonstrate that the discretionary decision which Congress intended authorizing officers to make had actually occurred. The Attorney General's statements that he was concerned only with probable cause and with form belie any policy of restraint at his level.

Even if the Court had considered this issue and had concluded that the requisite sentient review had occurred, however, there is another questionable aspect of the government's authorization procedure which the Supreme Court did not consider. Section 2516(1) requires an appropriate authorizing officer to approve submission of a Title III application to the issuing court. Other provisions of the statute indicate the intention of Congress that the applying attorney receive notice of authorization before appearing before the court. ${ }^{274}$ However, the misrepresentations involved in the government's standardized Title III documents frustrated that purpose. When applying attorneys asserted to issuing judges that Will Wilson had authorized their applications, they were in error. Assuming the government's revised version of what actually occurred within the Justice Department is correct, the question remains: Did the Attorney General effectively authorize the applying attorneys to proceed even though they did not know it?

Most courts never considered this issue because they generally regarded the misrepresentations concerning the authorization process either as dispositive or as irrelevant. ${ }^{275}$ However, in United States v. Vasquez, ${ }^{276}$ the district court voided a Title III court order despite the Attorney General's personal participation in the authorization process because neither the applying attorney nor the issuing court ever knew that the Attorney General had acted. The court's reasoning on this point is instructive:

I suppose all would agree that if the Attorney General one morning said to himself that he had decided to

${ }^{274}$ Such an intention is implicit in the requirements that the applying officer must state under oath the identity of the authorizing officer and that the issuing judge must identify the authorizing officer in the interception order itself. 18 U.S.C. $\S \S 2581(1)(a), 2518(4)(d)(1970)$.

275 See text accompanying notes 91-98 supra.

276348 F. Supp. 532 (C.D. Cal. 1972). 
authorize [the applying attorney] to apply for a wiretap order, this, of itself, would not constitute the authorization required by the statute. Do we have substantially more here? Assuming the Attorney General did make such a decision in his own mind and communicated it to Mr. Lindenbaum, the current awareness stopped there. Mr. Petersen had no such knowledge ....

[The applying attorney] certainly was not told that the Attorney General had made the decision . . . .

The statute (section 2518) [sic] says that the Attorney General “. . . may authorize an application to a Federal judge ..." I do not see how there can be an effective "authorization" under such statute if neither the person making the application nor the judge to whom he applies is aware of the existence of that authorization. ${ }^{277}$

There is little question that under standard agency law the government attorneys who submitted Title III applications to the federal courts on the basis of "Will Wilson" letters had apparent authority to do so. ${ }^{278}$ Furthermore, given the Attorney General's subsequent disclosure that he had personally approved the applications, those attorneys probably possessed actual authority as well. ${ }^{279}$ However, Congress did not enact the authorization requirements of section 2516(1) simply to ensure that Title III applications were authorized in the traditional principal-agency sense. Congress wanted to be certain that no attorney would even submit an application until he received prior approval from a politically responsive, senior

${ }^{277}$ Id. at $\check{5} 36$.

${ }^{278}$ Apparent authority exists when a principal acts in a manner which causes a third party reasonably to believe that the principal has authorized the agent to perform a certain act. Restatement (Second) of Agency § 27, at 103 (1958). Such apparent authority arises, for example, when the principal asserts in a letter that the agent possesses the authority, and a copy of the letter is formulated to the third party; or when the principal authorizes the agent to represent to the third party that the authority to perform the act exists. Id. 103-06.

279 Actual authority would not exist, according to the Restatement, unless the Attorney General had satisfactorily manifested his intent that the applying attorneys should submit their Title III applications by conduct which came to the attention of. the applying attorneys. Id. 100-01. The procedure which the Justice Department employed did communicate that intention, but misrepresented whose intention it was. However, such a mistake of fact would not destroy the authority of the applying attorneys under standard agency law if the Attorney General assumed responsibility for such factual errors. $I$ d. $137-38$. 
official of the Department of Justice. In a functional sense, deeming Title III applications to be properly authorized on the basis of the Attorney General's after-the-fact declarations is no different than approving the ratification by the Attorney General of an already submitted application, something which the courts have declared to be improper. ${ }^{280}$ By tolerating a situation in which government attorneys could mistakenly submit applications in the good faith belief that they had received an Assistant Attorney General's approval and invalidating some while sustaining others solely on the basis of the Attorney General's "ex post facto affidavit,"281 the Supreme Court ignored the congressional intention that the provisions of Title III prevent abuses before they occurred, not just repair those which had already happened. ${ }^{282}$ As one court noted,

It hardly fulfills the expressed intent of Congress to say that the true lines of responsibility may now be traced by means of affidavits submitted almost two years later by the Department of Justice for the purpose of contradicting the documents upon the basis of which the wiretap order was requested and issued..$^{283}$

Finally, it bears repeating that the best evidence of what the Attorney General actually accomplished when he initialed the form memorandum is the text of the memorandum itself. To the extent the memorandum is ambiguous, consideration of other factors, including the Attorney General's own statements of what he intended, would be proper. But if, as numerous courts have suggested, the purpose of the memorandum is perfectly clear, ${ }^{284}$ there is no legitimate reason to permit the government to controvert its contemporaneous statements of what it intended. Nevertheless, like many lower courts, the Supreme Court accepted the government's after-the-fact explanations, ignoring the Justice Department's posture as a somewhat desperate advocate. It thereby unquestioningly resolved in the government's favor an important issue in the case and transformed the straightforward statements of the government's Title III documents into a sophist's delight, in which no

${ }^{280}$ Giordano II, 416 U.S. at 523-24 n.12.

${ }^{281}$ Chavez $I I, 416$ U.S. at 588 (opinion of Douglas, J.).

${ }^{282}$ United States v. King, 335 F. Supp. 523, 545 (S.D. Cal. 1971), rev'd in part, 478 F.2d 494 (9th Cir.), cert. denied, 414 U.S. 846 (1973).

${ }^{283}$ United States v. Vasquez, 348 F. Supp. 532, 537 (C.D. Cal. 1972).

${ }^{284}$ See note 215 supra. 
word means what it says unless the speaker later chooses to make it so.

\section{ConCLUSION}

The manner in which most lower courts decided Title III misidentification cases demonstrates the ability of judges to evade the obvious and to foster the bizarre. In order to secure Title III court orders the government submitted sworn representations that Will Wilson had personally authorized submission of each application and substantiated those representations by what purported to be Wilson's personal letters. Subsequently, in order to sustain the Title III orders despite the inaccuracy of those representations, the government contended that the Attorney General himself had authorized the applications and that Wilson's only role was "a messengertype function which, under the statute at least, could have been performed by anyone." 285 Furthermore, the government also claimed that the form memorandum, the text of which instructed Wilson to perform a discretionary act, itself constituted performance of the act, thus making the instruction unnecessary. ${ }^{286}$ Despite their implausibility, however, these assertions succeeded in most federal courts.

One would be naive to believe that the government succeeded in so many cases by the simple force of logic. It is far more likely that many lower court judges accepted the government's contentions because refusing to do so would require the suppression of incriminating evidence of major federal crimes because of a statutory deviation. A number of courts suggested that under such circumstances the costs of suppression were too high. ${ }^{287}$ Furthermore, several courts which imposed the suppression sanction did so with obvious regret and in some cases bitterly castigated the Justice Department officials whose conduct had made such a disposition necessary. ${ }^{288}$

${ }^{285}$ Focarile, 340 F. Supp. at 1053.

${ }^{286}$ See United States v. Vasquez, 348 F. Supp. 532, 536 (C.D. Cal. 1972).

${ }^{287}$ The most explicit example of this suggestion is United States v. Kohne, 347 F. Supp. 1178, 1182 (W.D. Pa. 1972), in which the court concluded that the Justice Department's authorization process was proper and observed, " $[\mathrm{T}] \mathrm{o}$ hold otherwise would be to put form over substance and would negate the countless hours spent by law enforcement officials gathering evidence for this case."

${ }^{288}$ United States v. King, 478 F.2d 494, 505 (9th Cir.), cert. denied, 414 U.S. 846 
Those courts which condoned the government's conduct in order to avoid suppressing electronic interceptions improperly balanced the considerations involved. To be sure, the evidence involved in many cases was essential to the conviction of often sinister defendants. However, the countervailing considerations-the interests which Congress sought to protect-were not simply conformity to a statutorily required but otherwise pointless bureaucratic procedure. On the contrary, Congress intended to safeguard privacy itself. As the district court commented in finally disposing of the very first authorization case, the strict limitations established in Title III are essential to the statute's purpose:

One must not lose sight amidst all the debate, which superficially appears to center around a contest of words, that we are dealing here with a power which has, for by far the greatest part of our history, been forbidden to government under all but the very most limited circumstances. We are dealing with an awesome power which strikes directly at the heart of the right to privacy, which has been elevated in other contexts to the highest level of constitutional protection. That the power legitimately exists at all is beyond the understanding of many of our great legal and constitutional minds. ${ }^{289}$

The Supreme Court did not dispose of the misrepresentations in the government's Title III documents by adopting the approach of most lower courts. But it accomplished the same result. Instead of dismissing the government's misstatements as irrelevant or harmless error, the Court properly labeled them as violations of the statute. However, the majority avoided suppressing evidence on this basis by a novel construction of Title III's statutory suppression sanction, which limited its applicability to only those statutory violations which the Court regarded as central.

(1973); Giordano I, 469 F.2d at 531; United States v. Stanley, 360 F. Supp. 1112 (N.D. $\mathrm{Ga}$. 1973) (describing the case as part of "the continuing saga of the Government's gross carelessness" with respect to Title III applications); United States v. Robinson, 359 F. Supp. 52, 54 (S.D. Fla. 1973), rev'd per curiam, 496 F.2d 225 (5th Cir. 1974) (en banc); United States v. Casale, 341 F. Supp. 374, 375 (M.D. Pa.), rev'd sub nom. United States v. Ceraso, 467 F.2d 647 (3d Cir. 1972).

${ }^{289}$ United States v. Robinson, 359 F. Supp. 52, 57 (S.D. Fla. 1973), rev'd per curiam, 496 F.2d 225 (5th Cir. 1974) (en banc). 
In so doing, both the majority and the dissenters overlooked several important issues, despite the appellees' efforts to raise them. In particular, the Court ignored the intentional nature of the institutional misconduct which caused government attorneys to make sworn misstatements concerning the authorization process when seeking Title III court orders.

The Supreme Court also erred in not scrutinizing the government's characterizations of the Attorney General's own actions in cases in. which he personally participated in the authorization process. This uncritical acceptance of the government's after-the-fact representations was not unusual, and there are legitimate reasons for such an approach in most cases in which the Department of Justice makes positive factual assertions concerning the conduct of government officials. But in the authorization cases, whether the Attorney General's actions satisfied section 2516(1) was an issue of law. And caution would have been particularly appropriate because the record in these cases included incontrovertible evidence that Justice Department officials had taken extraordinary liberties with the statutory protections Congress had created to protect personal privacy against surreptitious intrusions by electronic means. ${ }^{290}$

In Giordano the Supreme Court properly suppressed Title III evidence which the government had obtained without authorization by any appropriate Justice Department official. However, in Chavez a majority of the Court substantially diminished the statutory protections which Congress mandated to enforce the authorization requirement. The result is hard to reconcile with the Court's own acknowledgement that Congress intended to permit electronic interceptions only in strict conformity to the stringent requirements of the statute.

More difficult to assess is the long range significance of the Court's decisions. In one sense the authorization cases were sui generis. They involved the propriety of an approval procedure which the Justice Department has since disavowed, and, unless the Court chooses to consider authorization decisions by the various acting Attorneys General who followed John N. Mitchell into office, ${ }^{291}$ it will probably never again

290 See, e.g., United States v. Robinson, 468 F.2d 189, 192 n.7 (5th Cir. 1972), remanded, 472 F.2d 973 (5th Cir. 1973) (en banc).

${ }^{291}$ See note 10 supra. 
consider the authorization and identification requirements of Title III. On the other hand, the Court's construction of Title III's statutory suppression sanction affects enforcement of the entire Act. The lower courts have been quick to adopt the Supreme Court's description of section 2518(10)(a) as applying only to violations of those Title III provisions which directly and substantially implement the central safeguards of the Act. In one case the District of Columbia Court of Appeals relied upon this formula to reject the government's argument that its failure to disclose the existence of prior applications did not necessitate disclosure. ${ }^{292}$ However, other courts have relied upon the same formula to deny suppression despite a violation of Title III's post-interception procedural requirements ${ }^{293}$ or to limit the suppression sanction to those cases in which the government committed a Title III violation willfully rather than through inadvertance. ${ }^{294}$ These decisions suggest that the lower courts will accept the Supreme Court's invitation to "pick and choose" among the different provisions of Title III, suppressing evidence in some cases and refusing suppression in others. Such a trend can only further weaken the ability of the statute to protect individual privacy in the manner Congress intended.

${ }^{292}$ United States v. Bellosi, 501 F.2d 833, 840-41 (D.C. Cir. 1974).

${ }^{293}$ United States v. Falcone, 505 F.2d 478, 483-84 (3d Cir. 1974); $c f$. United States v. John, No. 72-1565 (8th Cir., Jan. 6, 1975) (finding no violation of post-interception procedural requirements of $\S 2518(8)(d))$.

294 United States v. Chun, 503 F.2d 533, 542 (9th Cir. 1974). 